Article

\title{
A Novel Series of $[1,2,4]$ Triazolo[4,3-a]Pyridine Sulfonamides as Potential Antimalarial Agents: In Silico Studies, Synthesis and In Vitro Evaluation
}

\author{
Veronika R. Karpina ${ }^{1}{ }^{1}$, Svitlana S. Kovalenko ${ }^{1}$, Sergiy M. Kovalenko ${ }^{2,3}{ }^{(D)}$, \\ Oleksandr G. Drushlyak ${ }^{1, *}$, Natalya D. Bunyatyan ${ }^{3,4}$, Victoriya A. Georgiyants ${ }^{1}{ }^{\circledR}$, \\ Vladimir V. Ivanov ${ }^{2} \mathbb{D}$, Thierry Langer ${ }^{5}$ and Louis Maes ${ }^{6}(\mathbb{D}$ \\ 1 Department of Pharmaceutical Chemistry, National University of Pharmacy, 53 Pushkinska str., \\ 61002 Kharkiv, Ukraine; v.karpina01@gmail.com (V.R.K.); s.kovalenko.nphau@gmail.com (S.S.K.); \\ vgeor@ukr.net (V.A.G.) \\ 2 Department of Organic Chemistry, V.N. Karazin Kharkiv National University, 4 Svobody Sq., 61022 Kharkiv, \\ Ukraine; kovalenko.sergiy.m@gmail.com (S.M.K.); vivanov5001@gmail.com (V.V.I.) \\ 3 Federal State Autonomous Educational Institution of Higher Education I.M. Sechenov First Moscow State \\ Medical University of the Ministry of Health of the Russian Federation (Sechenov University), \\ 8-2 Trubetskaya str., Moscow 119991, Russia; ndbun@mail.ru \\ 4 Federal State Budgetary Institution 'Scientific Centre for Expert Evaluation of Medicinal Products' of the \\ Ministry of Health of the Russian Federation, Petrovsky boulevard 8, bld. 2, Moscow 127051, Russia \\ 5 Department of Pharmaceutical Chemistry, University of Vienna, Althanstraße 14, A-1090 Vienna, Austria; \\ thierry.langer@univie.ac.at \\ 6 Laboratory of Microbiology, Parasitology and Hygiene, University of Antwerp, Universiteitsplein 1, \\ B-2610 Antwerp, Belgium; louis.maes@uantwerpen.be \\ * Correspondence: aldry18@hotmail.com; Tel.: +38-050-196-5129
}

Received: 1 September 2020; Accepted: 24 September 2020; Published: 30 September 2020

\begin{abstract}
For the development of new and potent antimalarial drugs, we designed the virtual library with three points of randomization of novel $[1,2,4]$ triazolo[4,3-a]pyridines bearing a sulfonamide fragment. The library of 1561 compounds has been investigated by both virtual screening and molecular docking methods using falcipain-2 as a target enzyme. 25 chosen hits were synthesized and evaluated for their antimalarial activity in vitro against Plasmodium falciparum. 3-Ethyl-N-(3-fluorobenzyl)- $N$-(4-methoxyphenyl)-[1,2,4]triazolo[4,3-a]pyridine-6-sulfonamide and 2-(3-chlorobenzyl)-8-(piperidin-1-ylsulfonyl)-[1,2,4]triazolo[4,3-a]pyridin-3(2H)-one showed in vitro good antimalarial activity with inhibitory concentration $\mathrm{IC}_{50}=2.24$ and $4.98 \mu \mathrm{M}$, respectively. This new series of compounds may serve as a starting point for future antimalarial drug discovery programs.
\end{abstract}

Keywords: [1,2,4]triazolo[4,3-a]pyridines; sulfonamide; Plasmodium falciparum; antimalarial; falcipain-2; virtual screening; molecular docking

\section{Introduction}

Parasitic protozoal diseases have an enormous health, social and economic impact and are a particular problem in tropical regions of the world. These diseases include malaria, Chagas disease, human African trypanosomiasis, and leishmaniasis. The current chemotherapeutic options for these aggresive diseases can have severe side effects, may be ineffective, or even non-existent, and in cases where a drug treatment is available, resistance is emerging [1]. Malaria is a mosquito-borne infectious disease, which causes high morbidity and mortality rates worldwide. In 2018, malaria parasites threatened the lives of 228 million of people and caused 405,000 deaths. Most of these deaths occurred in 
the African Region (93\%), followed by the South-East Asia Region (3.4\%) and the Eastern Mediterranean Region (2.1\%). Children under 5 years are particularly susceptible to malaria illness, infection and death. In 2018, malaria killed an estimated 272,000 (67\% of total death) children under five years of age globally [2]. Six Plasmodium species are responsible for developing malaria in humans [3], however, the most lethal is Plasmodium falciparum. Thus, there is a constant need to discover and develop new antimalarial drugs, which are effective against multi-drug resistant parasites.

The biological activity of a compound, defined by the affinity of a small-molecule ligand towards the macromolecular receptor, can be explored by using in silico methods and completed with experimental methods. The constant discovery of novel anti-parasitic drug target proteins and free availability of their 3-D structures in protein data banks give an opportunity to find novel active inhibitors against previously known targets. Recently, virtual screening (VS) was routinely used as a supplement to or as a replacement for high-throughput screening in lead identification, due to virtual screening's savings in time and money. Antimalarial studies of lead identification using VS were reported in the literature, either structure-based virtual screening (SBVS) $[4,5]$ or ligand-based virtual screening (LBVS) [6]. The mentioned approaches are often used in combination with such methods as pharmacophore modeling, 3D QSAR and molecular docking techniques in order to prioritize molecules for testing and minimize the number of compounds to be investigated in biological screens. For example, Elumalai P. et al. [7] reported the discovery of novel inhibitors for the P. falciparum dihydroorotate dehydrogenase (PfDHODH), a key enzyme in the de novo pyrimidine biosynthesis pathway via a combination of the pharmacophore and SBVS approaches using 3D-QSAR pharmacophore models and docking studies. The in vitro antiplasmodial activity revealed three promising hits with $\mathrm{IC}_{50} \leq 20 \mu \mathrm{M}$. The LBVS in combination with pharmacophore modeling has been used by Paul B. M. et al. [8] in the discovery of novel small molecule inhibitors of the plasmepsin aspartyl proteases, active against P. falciparum. V.K. Vyas et al. [9] claimed that structure-based pharmacophore modeling, virtual screening, docking and biological evaluation are the rational strategies for the identification of novel hits or leads with diverse chemical scaffolds. In their studies, in silico ADMET prediction was also conducted. In vivo antimalarial activity showed good potential for two compounds to become novel PfDHODH inhibitors.

As a follow up to our previous study [10], in collaboration with Laboratory of Microbiology, Parasitology and Hygiene, University of Antwerp, we paid attention to triazolopyridine scaffold bearing sulfonamide group as chemical entity with potential antimalarial activity. Triazolopyridines represents an important class of heteroaromatic compounds with a wide range of pharmaceutical and biological activities including antibacterial, antifungal [11], anti-inflammatory [12-14], herbicidal [15] and pesticidal [16], anticonvulsant [17], anxiolytic [18], and antipsychotic [19]. Triazolopyridine compounds bearing sulfonamide substituent are useful for the treatment of cystic fibrosis [20,21]. Recently, compound DSM265 with a triazolopyrimidine scaffold, which is bioisosteric to triazolopyridine scaffold, was found to be a PfDHODH inhibitor. This compound showed an encouraging safety profile in a Phase I trial and is currently in clinical development [22]. The sulfonamide functional group is widely used in medicinal chemistry because of its low toxicity and excellent biological activity. Sulfadoxine [23], Sulfolene and Sulfadiazine [24] are among the effective malaria drugs containing sulfonamide groups attached to a heterocyclic ring. A large number of sulfonamide derivatives were obtained by alkylation of the nitrogen of the sulfamide group. In particular, there is information about the antiprotozoal activity of sulfonamide derivatives. In 2007, Da Silva et al. demonstrated that synthetically prepared $N$-quinolin-8-yl-arylsulfonamides and their complexes show significant anti-parasitic activity in vitro against Trypanosoma cruzi, Leishmania chagasi and L. Amazonensis [25]. Sulfonamides are also used in combination with pyrimethamine for the treatment of drug-resistant malaria and for toxoplasmosis [26]. The literature describes several other sulfonamides with antimalarial activity [27-29]. Given the threat of antimalarial drug resistance, there is an increasing need to develop alternative treatments, novel agents, that act via a unique mechanism of action relative to currently used drugs. 
Target identification is one of the most difficult tasks in developing new antimalarial drugs. The complex life cycle associated with Plasmodium falciparum provides a great number of targets, which can be explored to discover new drugs for the treatment of malaria. During its life span, a parasite plays an important role in metabolite synthesis, membrane transport and haemoglobin degradation. The targets, which are involved in these processes, can be used to inhibit parasitic growth by their inhibition. The best-characterized P. falciparum cysteine proteases are the falcipains that share sequence identity and other features with papain family cysteine proteases [30]. Among the four P. falciparum cysteine proteases, FP-2 is the most intensely studied enzyme and it appears to be the essential food vacuolar hemoglobinases [31]. Thus, inhibiting this target could prevent haemoglobin hydrolysis, which definitely hindered parasitic growth [32]. Indeed, any stoppage or even hindrance of the ability of $P$. falciparum to degrade the human haemoglobin through its cysteine protease kills P. falciparum [33], most especially at the Trophozoite stage of its development, when the FP-2 plays an important role in the parasite life cycle. [34]. This makes FP-2 an important antimalarial drug target because its inhibition kills the malaria-causing P. falciparum. At present, the main classes of known falcipain-2 inhibitors are peptides or peptidomimetic-bearing pharmacophores of cysteine protease inhibitors, such as vinyl sulfones, halomethyl ketones, and aldehydes. Furthermore, some nonpeptidic compounds have been identified as inhibitors of FP-2, such as isoquinolines, thiosemicarbazones, and chalcones [31].

With the aim of developing novel and potent antimalarial compounds, we designed the library of $[1,2,4]$ triazolo[4,3-a]pyridines, bearing a sulfonamide fragment. Three points of randomization were provided: the 1st was the position of sulfonamide substituent (6 or 8$)$, the 2 nd was substituent in triazole ring (3-H or lower alkyl, 2-benzyl-3(2H)-one, 3-benzylthio) and the 3rd was variation in sulfonamide substituent (Scheme 1).

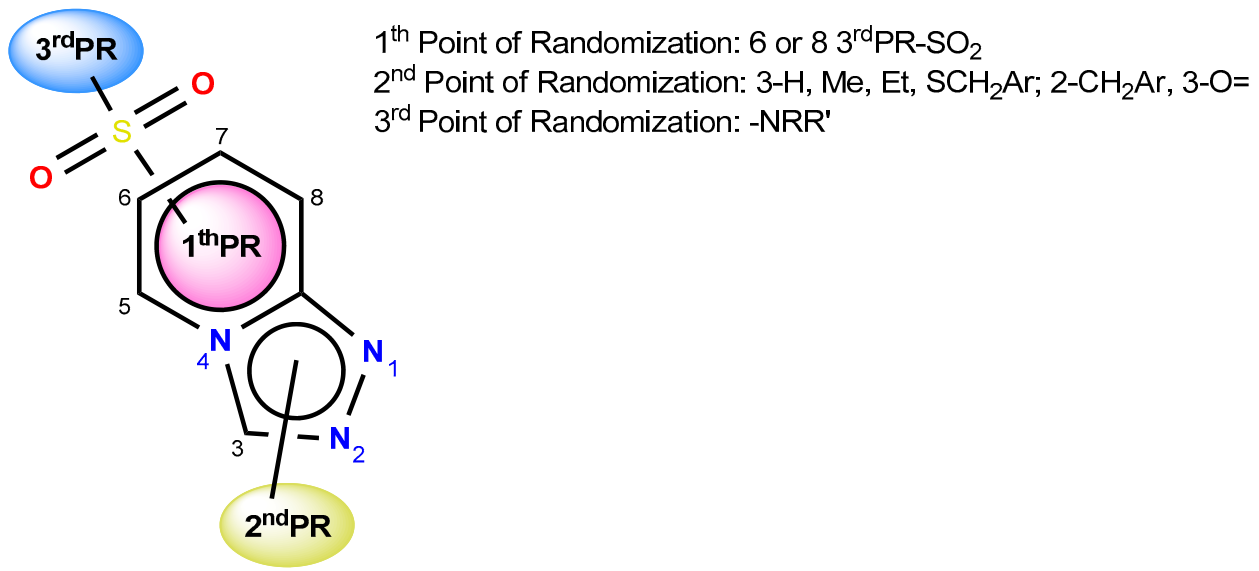

Scheme 1. Points of randomization of the library of $[1,2,4]$ triazolo[4,3-a]pyridines.

An SBVS approach in combination with pharmacophore modeling using LigandScout was applied for library analysis. Subsequently, the hits with good pharmacophoric fit values were docked into the crystal structure of FP-2 using AutoDock Vina and filtered accordingly. Following this, 25 hits were selected for the synthesis. All synthesized compounds were analyzed in vitro for chloroquine-resistant P. falciparum 2/K 1-strain.

\section{Results and Discussion}

\subsection{Pharmacophore Model Generation, Virtual Screening and Molecular Docking}

We selected the complex of Falcipain-2 with the epoxysuccinate E64 for our molecular modeling studies (pdb entry 3BPF). Cocrystallized FP2-E64 consists of residues 1-241 of the mature enzyme. The active site of enzyme is located in a cleft between the structurally distinct domains of the 
papain-like fold. The sulfhydryl group in the active site of cysteine protease FP2 forms a covalent, irreversible hemithioketal with the E64 epoxide group [35,36].

The mentioned complex was then used as a starting point for an extensive investigation of the chemical features important for ligand-protein interaction, and thus for pharmacophore generation by means of the software LigandScout. LigandScout generates structure-based pharmacophore models with the most important chemical features such as hydrogen bonds, charge interactions and hydrophobic areas. While hydrogen bond features are defined by direction and distance constraints, hydrophobic interactions and ionizable areas have a distance constraint only. In addition to LigandScout's supported chemical features, the program analyzes the shape of the active site and places excluded volume spheres in positions that are sterically claimed by the macromolecular environment. Initially, the re-docking methodology was performed with AutoDock Vina using the ligand from each chain. The root-mean-square deviation (RMSD) values of the heavy atoms in the re-docked ligands were $2.55,2.65,2.63,2.54 \AA$ for chains A, B, C and D respectively. This re-docking procedure showed that there are no significant differences in the crystallographic and docked ligand-protein complexes. Besides, the analysis of docking results was performed based on the main ranking criteria meaning Binding Energy (or Affinity, $\mathrm{kcal} / \mathrm{mol}$ ). As for Binding Affinity Score, it is a much-formalized parameter, which is calculated and used in different ways in different programs. The BAS parameter has been calculated with the LigandScout default criteria. For further studies, we chose the chain $\mathrm{D}$ with the lowest RMSD value. The pharmacophore model was generated based on the mentioned crystal structure and contained eight features: four hydrogen bond donors (HBD), three hydrogen bond acceptors (HBA), one hydrophobic group (Figure 1). Moreover, the software automatically increases the selectivity of the generated pharmacophore with the excluded volumes. LigandScout analyzes the shape of the active site and places excluded volume spheres in positions that are sterically claimed by the macromolecular environment. This process ensures that molecules retrieved via virtual screening match the sterical requirements of the active site, while simultaneously drastically increasing selectivity [37].<smiles>C=C(C)C=CCCCCC(=O)C(CC(C)C)C(=S)NC1CC1(C)C(=C)C</smiles>
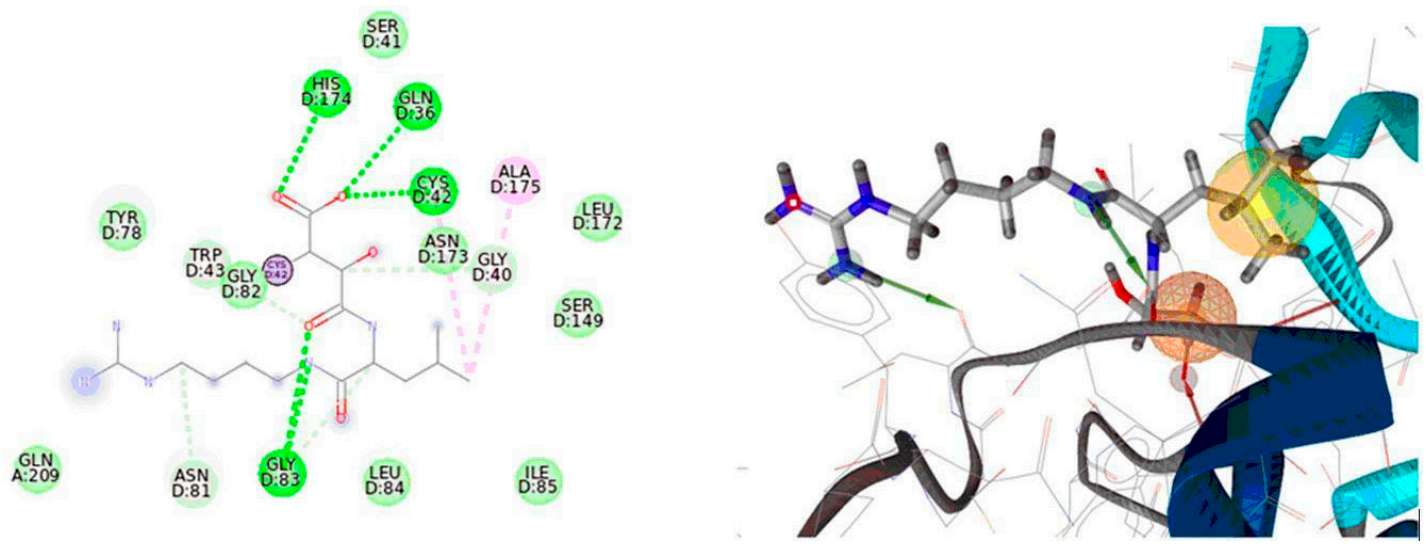

Figure 1. Ligand E64 and pharmacophore model generated within LigandScout from falcipain-2/ epoxysuccinate E64 complex for D chain in 2D and 3D view. 
As one can see from Figure 1, the E64-protein complex characterizes several important interactions of the active site. Among them the hydrogen bond acceptors are Cys42, Gln36, His174 and Gly83, and hydrogen bond donors are Ala175 and Asn173.

Then the in-house library of 1561 compounds was filtered by virtual screening procedure using the generated model. A total of 150 compounds with the highest pharmacophore-fit score, well-fitted to the pharmacophore model, were chosen for the docking calculations. Afterwards, the poses of every ligand were visualized and the protein-ligand binding energies were obtained. The most important ligand-protein binding properties, as well as corresponding physico-chemical parameters of the aforementioned hits, are presented in Table 1 . Then, the structures were ranked and the best 25 hits were chosen for synthesis and biological assay. The main ligand-protein binding properties and corresponding physico-chemical parameters of the mentioned hits are presented in Table 1.

Table 1. Binding affinity parameters and molecular properties of 25 hit compounds filtered by structure-based virtual screening (SBVS) and docking using protein-ligand complex FP-2/E64, chain D with (pdb: 3 bpf).

\begin{tabular}{|c|c|c|c|c|c|c|c|}
\hline Ligand & $\begin{array}{c}\text { Binding } \\
\text { Energy } \\
\text { (kcal/mol) }\end{array}$ & $\begin{array}{l}\text { Binding } \\
\text { Affinity } \\
\text { Score }\end{array}$ & cLogP & $\begin{array}{c}\text { Mol } \\
\text { Weight }\end{array}$ & $\begin{array}{l}\text { Hydrogen } \\
\text { Bond Donors } \\
\text { (HBA) }\end{array}$ & $\begin{array}{c}\text { Hydrogen } \\
\text { Bond Acceptors } \\
\text { (HBD) }\end{array}$ & $\begin{array}{c}\text { Topological Polar } \\
\text { Surface Area (TPSA) }\end{array}$ \\
\hline $13 e$ & -15.9 & -3.94 & 1.52 & 457.51 & 6 & 0 & 107.91 \\
\hline $13 \mathrm{~g}$ & -15.6 & -8.43 & 3.22 & 400.50 & 4 & 0 & 76.68 \\
\hline $8 \mathrm{~h}$ & -15.5 & -16.71 & 5.02 & 430.89 & 5 & 0 & 67.57 \\
\hline $8 d$ & -15.5 & -10.46 & 3.69 & 440.48 & 5 & 0 & 107.01 \\
\hline $15 f$ & -15.5 & -9.37 & 5.10 & 454.55 & 6 & 0 & 67.57 \\
\hline $13 c$ & -15.3 & -20.01 & 2.95 & 408.43 & 6 & 0 & 76.68 \\
\hline $15 \mathrm{c}$ & -15.3 & -16.10 & 4.30 & 402.54 & 5 & 0 & 67.57 \\
\hline $8 a$ & -15.2 & -9.45 & 4.85 & 434.85 & 6 & 0 & 67.57 \\
\hline $8 b$ & -15.2 & -9.27 & 5.46 & 434.56 & 4 & 0 & 67.57 \\
\hline $13 h$ & -15.2 & -9.23 & 3.05 & 404.46 & 5 & 0 & 76.68 \\
\hline $8 f$ & -15.1 & -13.39 & 4.68 & 410.47 & 5 & 0 & 67.57 \\
\hline $13 f$ & -14.9 & -15.77 & 3.32 & 406.89 & 4 & 0 & 76.68 \\
\hline $8 \mathrm{~g}$ & -14.9 & -15.02 & 5.02 & 430.89 & 5 & 0 & 67.57 \\
\hline $13 a$ & -14.9 & -6.36 & 3.32 & 406.89 & 4 & 0 & 76.68 \\
\hline $8 e$ & -14.8 & -12.24 & 4.63 & 440.50 & 6 & 0 & 76.80 \\
\hline $13 b$ & -14.8 & -1.08 & 3.33 & 416.46 & 4 & 0 & 102.96 \\
\hline $15 b$ & -14.7 & -24.47 & 4.75 & 467.41 & 5 & 0 & 67.57 \\
\hline $13 i$ & -14.7 & -5.87 & 2.37 & 408.47 & 6 & 0 & 76.68 \\
\hline $15 a$ & -14.6 & -21.83 & 4.00 & 418.54 & 6 & 0 & 76.80 \\
\hline $8 c$ & -14.6 & -10.35 & 4.85 & 436.53 & 5 & 0 & 76.80 \\
\hline $8 \mathrm{i}$ & -14.4 & -12.31 & 5.02 & 430.89 & 5 & 0 & 67.57 \\
\hline $15 d$ & -14.3 & -20.25 & 4.26 & 408.93 & 5 & 0 & 67.57 \\
\hline $3 \mathbf{j}$ & -14.3 & -8.49 & 3.02 & 442.92 & 6 & 0 & 76.68 \\
\hline $13 d$ & -14.3 & -2.59 & 2.17 & 408.86 & 5 & 0 & 85.91 \\
\hline $15 e$ & -14.0 & -23.42 & 4.26 & 408.93 & 5 & 0 & 67.57 \\
\hline E64 & -10.8 & -7.81 & -5.49 & 359.43 & 5 & 6 & 182.20 \\
\hline Chloroquine & -11.0 & -5.59 & 4.81 & 319.90 & 1 & 1 & 28.16 \\
\hline
\end{tabular}

The retrieved hits showed interactions with key amino acid residues near the active site, which included GLN36D, GLY83D, ALA175D, ILE85D, LEU84D and CYS42D. The binding modes and docking scores of retrieved hits were compared with the reference inhibitor E64 in order to evaluate the docking results, and it was found that all 25 compounds showed better interactions than E64 in the binding cavity of the enzyme. The binding energy values against the FP-2 ranged from 15.9 to $14 \mathrm{kcal} / \mathrm{mol}$ when compared to the reference ligand with $-10.80 \mathrm{kcal} / \mathrm{mol}$.

Compounds 13e and $13 \mathrm{~g}$ have the highest binding energies of -15.9 and $-15.6 \mathrm{kcal} / \mathrm{mol}$, respectively. The binding site interactions between 13e and FP-2 are illustrated in Figure 2 in $2 \mathrm{D}$ and $3 \mathrm{D}$ view. The triazolopyridine ring system forms a hydrogen-bond between Cys42 and the nitrogen N1. Two sulfonamide oxygen atoms formed H-bonds with the $\mathrm{H}$ atoms of Ala175 and Gly83- $\mathrm{NH}_{2}$ groups. The 3-Methylbenzyl group of $\mathbf{1 3} \mathbf{g}$ compound was in contact with the hydrophobic pocket formed by Ile85 and Leu84. A 2D and 3D view of binding site interactions are illustrated in Figure 3. Non-hydrophobic interaction included H-bonds between the Ala175/N1 atom and the Gly83/oxygen atom of the triazolopyridine ring system. 

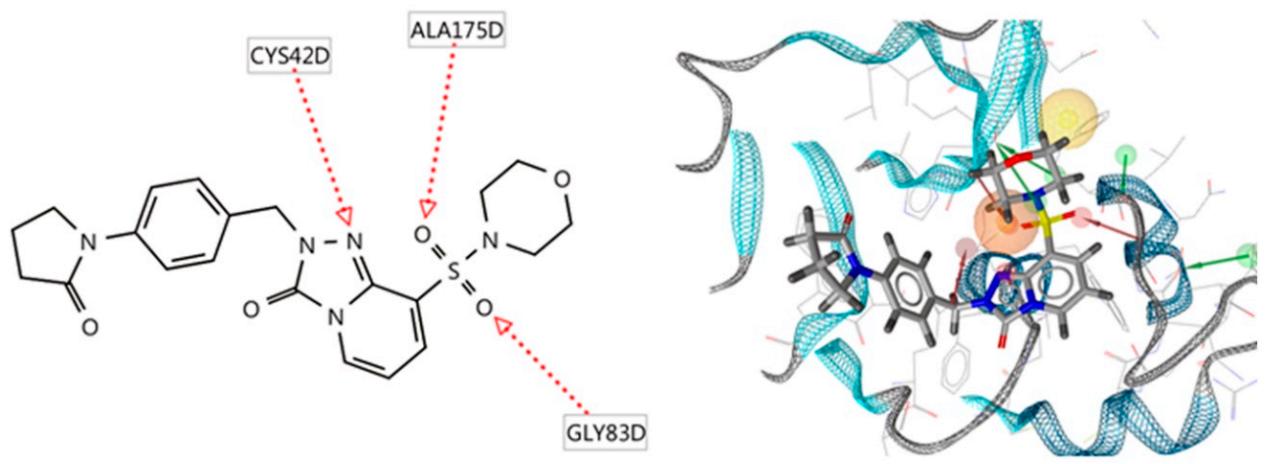

Figure 2. Binding site interactions of 13e in FP-2 enzyme proposed by docking studies in 2D (left side) and 3D (right side) view. HBA-red vectors.
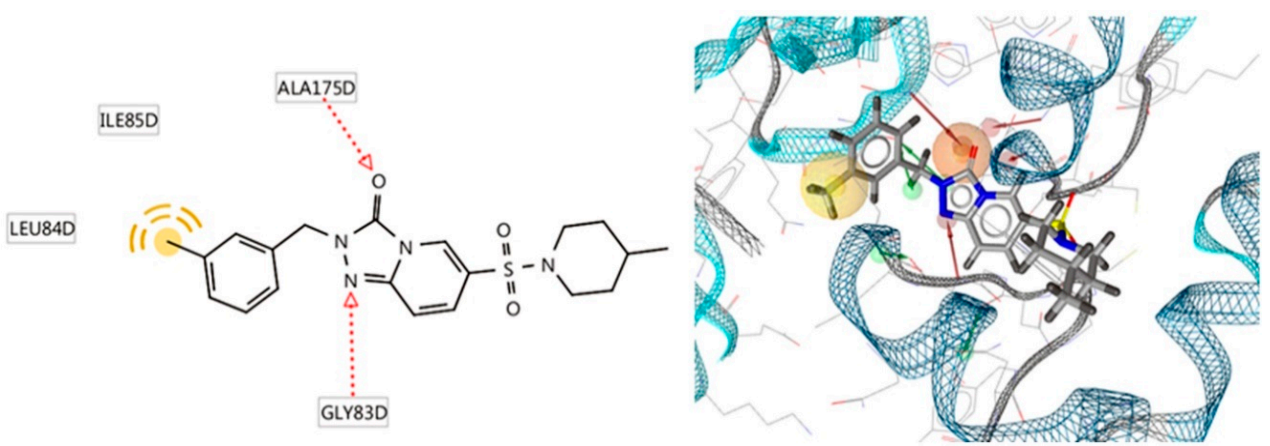

Figure 3. Binding site interactions of $\mathbf{1 3 g}$ in FP-2 enzyme proposed by docking studies in 2D (left side) and 3D (right side) view. HBA—red vectors, hydrophobic group-yellow area.

The review of other compounds showed the following binding interactions:

- Oxygen atoms of sulfonamide group were most commonly involved in interactions with Gln36, Cys42, Gly83 amino acids for all compounds, except 13i and 15b;

- $\quad$ N1 atom of fused triazolopyridine ring system was involved in hydrogen bonding with Ala175 (13a, 13b, 13d, 13c), Cys42 (15e, 15c, 15a, 15b), Gly83 (15d, 13i) and Gln36 (8e);

- $\quad$ N2 atom of fused triazolopyridine ring system was involved in hydrogen bonding with Gly83 $(\mathbf{8 a}, \mathbf{8 b}, \mathbf{8 c}, \mathbf{1 5 f}, \mathbf{1 5 d})$ and $\mathrm{Gln} 36(\mathbf{1 5 e}, \mathbf{1 5 c}, \mathbf{1 5 a})$;

- Oxygen atom in the 3 position of fused triazolopyridine ring system was involved in hydrogen bonding with Gly83 (13b, 15d, 13f, 13h, 13j) and Ala175 (13i);

- $\quad$ Amino acids such as Ile 85, Leu 84 were most commonly involved in hydrophobic interactions for all compounds, except 8a, 8b, 8c, 15f, 15e, 15c, 15a.

The docking study suggested that these interactions contributed to the potent binding of the retrieved hits. Based on the interaction results, all 25 compounds, including chloroquine, showed interactions with at least two main amino acid residues of the enzyme active site. It is to be noted that none of the compounds from the library showed interaction with His174.

\subsection{Chemistry}

The reaction sequences started from commercially available 2-chloropyridine-3-sulfonyl chloride $\mathbf{1 a}$ or 2-chloropyridine-5-sulfonyl chloride $\mathbf{1 b}$ to provide the first randomization point in the position of the sulfonamide substituent (Schemes 2 and 3). The chosen strategy of synthesis involved the further introduction of a benzyl substituent at the nitrogen atom of sulfonamide group to create the new randomization point, therefore, sulfonyl chlorides $\mathbf{1} \mathbf{a}, \mathbf{b}$ were treated by primary anilines $\mathbf{2} \mathbf{a}-\mathbf{g}$ to produce 2-chloro- $N$-(aryl)pyridinesulfonamides $\mathbf{3 a - g}$. The chlorine atom in compounds $\mathbf{3 a - g}$ was replaced by action of hydrazine hydrate in $i$-propanol to provide 2-hydrazinyl- $N$-(aryl)pyridinesulfonamides 
4a-g. Synthesis of $[1,2,4]$ triazolo[4,3-a]pyridinesulfonamides $\mathbf{6 a}-\mathbf{g}$ was performed by the reaction of ortho-esters 5a-c with compounds $\mathbf{4 a - g}$ in DMF with reflux for $16 \mathrm{~h}$. Further, benzyl substituent was introduced by alkylation of compounds $6 \mathbf{a}-\mathbf{g}$ by action of benzyl chlorides $7 \mathbf{a}-\mathbf{h}$ due to the nucleophilic properties of NHSO-group. As a result, we obtained novel $N, N$-disubstituted $[1,2,4]$ triazolo[4,3-a]pyridinesulfonamides 8a-i (Scheme 2), (Table 2).

Syntheses of novel 6- and 8-sulfonamido[1,2,4]triazolo[4,3-a]pyridin-3-one derivatives 13a-j, and their 3-thio analogues 15a-f were performed by analogy with the known synthetic pathway $[20,38]$ shown in Scheme 3. Since the alkylation of unsubstituted sulfonamido[1,2,4]triazolopyridin-3-ones, and especially 3-thioxo[1,2,4]triazolo[4,3-a]pyridines, can lead to two different alkylation products (with substituent at the sulfonamide nitrogen or at the nitrogen at 2-position of the triazole moiety or at the sulfur atom), therefore, in order to obtain target products with the only possible and strictly defined structure, secondary amines 9a-f were chosen to prepare sulfonamides $10 \mathrm{a}-\mathrm{g}$. This excluded further alkylation of the sulfonamide group. The reactions conditions for syntheses of 2-chloro- $N$-substitutedpyridinesulfonamides 10a-g and 2-hydrazinyl- $N$-substitutedpyridinesulfonamides 11a-g (Scheme 3) were similar to the reaction conditions described above (Scheme 2). Sulfonamido[1,2,4]triazolopyridin-3-ones 12a-e were prepared by cyclization of the corresponding hydrazines 11a-e with an excess of CDI in anhydrous dioxane with reflux for $8 \mathrm{~h}$. Subsequent alkylation was produced by the action of benzyl chlorides $7 \mathbf{a}, \mathbf{e}-\mathbf{g}, \mathbf{i}-\mathbf{n}$ in DMF at $100{ }^{\circ} \mathrm{C}$ in the presence of excess of $\mathrm{K}_{2} \mathrm{CO}_{3}$ and resulted in the formation of 2-benzyl-sulfonamido[1,2,4]triazolopyridin-3-ones 13a-j. 3-Thioxo-sulfonamido[1,2,4]triazolopyridines 14a-c were synthesized by the reaction of $\mathrm{CS}_{2}$ with 2-hydrazinyl- $N$-substitutedpyridinesulfonamides 11a,f,g in DMF with the presence of triethylamine. Further alkylation of compounds 14a-c was carried out by the action of benzyl chlorides $\mathbf{7 a}, \mathbf{c}, \mathbf{h}, \mathbf{k}, \mathbf{o}, \mathbf{p}$ in DMF at $80{ }^{\circ} \mathrm{C}$ in the presence of triethylamine, and gave 3-thio-sulfonamido[1,2,4] triazolo[4,3-a]pyridines 15a-f with high yields (Scheme 3), (Table 3).

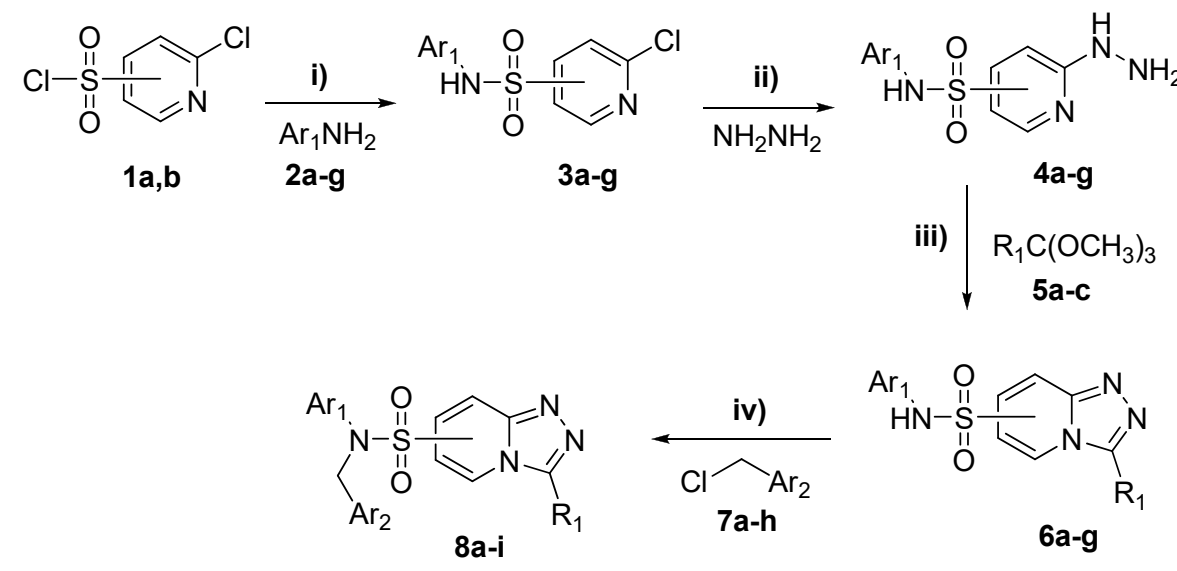

1a, 3a,b, 4a,b: 3-SO $\mathrm{SO}_{2}$-pyridine; 1b, 3c-g, 4c-g: 5-SO - -pyridine;

6a,b, 8a-c: $8-\mathrm{SO}_{2} \mathrm{~N} ; 6 \mathrm{c}-\mathrm{g}, 8 \mathrm{~d}-\mathrm{i}: 6-\mathrm{SO}_{2} \mathrm{~N}$;

2a, 3a, 4a, 6a, 8a: $\mathrm{Ar}_{1}=3,5-d i F P h ; 2$ b, 3b, 4b, 6b, 8b,c: $\mathrm{Ar}_{1}=3,5-d i M e P h ;$

2c, 3c, 4c, 6c, 8d: $\mathrm{Ar}_{1}=3-\mathrm{MePh}$; 2d, 3d, 4d, 6d, 8e: $\mathrm{Ar}_{1}=4-\mathrm{MeOPh}$;

2e, 3e, 4e, 6e, 8f: $\mathrm{Ar}_{1}=4-F P h ; 2 f, 3 f, 4 f, 6 f, 8 g: \mathrm{Ar}_{1}=3-\mathrm{CIPh}$;

2g, 3g, 4g, 6g, 8h: $\mathrm{Ar}_{1}=4-\mathrm{CIPh}$;

5a, 6a, 8a: $R_{1}=H ;$ 5b, 6b,c,e-g, 8b-d,f-h: $R_{1}=M e ; 5 c, 6 d, 8 e: R_{1}=E t ;$

7a, 8a,g: $\mathrm{Ar}_{2}=3-\mathrm{CIPh}$; 7b, 8b: $\mathrm{Ar}_{2}=2,5-d i M e P h ; 7 c, 8 c: \mathrm{Ar}_{2}=4-\mathrm{MeOPh}$;

7d, 8d: $\mathrm{Ar}_{2}=$ methyl (furan-5-yl)-2-carboxylate; 7e, 8e: $\mathrm{Ar}_{2}=3-\mathrm{FPh}$;

7f, 8f: $\mathrm{Ar}_{2}=3-\mathrm{MePh}$;g, 8h: $\mathrm{Ar}_{2}=2-\mathrm{FPh} ; \mathbf{7 h}, \mathbf{8 i}: \mathrm{Ar}_{2}=4-\mathrm{FPh}$

Scheme 2. Synthesis of compounds 8a-i. (i) Triethylamine, dioxane, $60{ }^{\circ} \mathrm{C}, 3 \mathrm{~h}$; (ii) $\mathrm{N}_{2} \mathrm{H}_{4}$, $i$-propanol, reflux, $4 \mathrm{~h}$; (iii) DMF, reflux, $16 \mathrm{~h}$; (iv) $\mathrm{K}_{2} \mathrm{CO}_{3}, \mathrm{DMF}, 90^{\circ} \mathrm{C}, 2 \mathrm{~h}$. 
<smiles></smiles>

$1 a, b$<smiles>[R]N[R3]</smiles><smiles></smiles>

$10 a-g$
$\underset{\mathrm{NH}_{2} \mathrm{NH}_{2}}{\stackrel{\text { ii) }}{\longrightarrow}}$

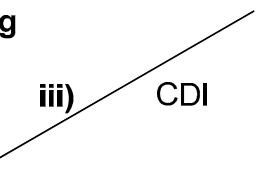<smiles>[R3]N([R4])S(=O)(=O)c1ccc(NN)nc1</smiles>

$11 a-g$

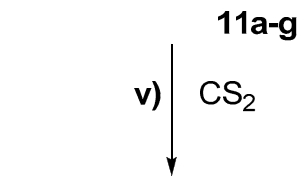<smiles>[R3]N([R3])S(=O)(=O)c1ccc2n[nH]c(=S)n2c1</smiles>

$14 a-c$

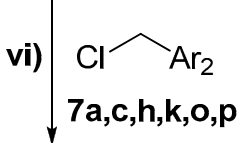<smiles></smiles>

1a, 10a,b,e-g, 11a,b,e-g: 3-SO ${ }_{2}$-pyridine; 1b, 10c,d, 11c,d: 5-SO $\mathrm{SO}_{2}$-pyridine;

12a,b, 13a-e, 14a-c, 15a-f: 8- $\mathrm{SO}_{2} \mathrm{~N}$; 12c-e, 13f-j: 6- $\mathrm{SO}_{2} \mathrm{~N}$;

$7 \mathbf{i} \mathrm{Ar}_{2}=$ benzo[d] [1,3]dioxol-5-yl; 7j $\mathrm{Ar}_{2}=3,5-d i F P h ; ~ 7 k ~ \mathrm{Ar}_{2}=2-\mathrm{CIPh}$;

7I $\mathrm{Ar}_{2}=4$-(2-oxopyrrolidin-1-yl)phenyl; 7m $\mathrm{Ar}_{2}=4-\mathrm{CIPh} ; \mathbf{7 n ~} \mathrm{Ar}_{2}=2-\mathrm{Cl}-4-\mathrm{FPh} ; 70 \mathrm{Ar}_{2}=3-\mathrm{BrPh}^{2}$ 7p 4-MePh;

9a, 10a, 11a, 12a, 13a-c, 14a, 15a-c: $\mathrm{R}_{3} \mathrm{NR}_{4}=\mathrm{N}$-piperidinyl; 13a $\mathrm{Ar}_{2}=3-\mathrm{CIPh}$;

13b $\mathrm{Ar}_{2}=$ benzo[d][1,3]dioxol-5-yl; 13c $\mathrm{Ar}_{2}=3,5-$ diFPh;15a $\mathrm{Ar}_{2}=4-\mathrm{MeOPh} ; 15 \mathrm{~b} \mathrm{Ar} 2=3-\mathrm{BrPh}_{2}$

$15 \mathrm{c} \mathrm{Ar}_{2}=4-\mathrm{MePh}$;

9b, 10b, 11b, 12b, 13d,e: $R_{3} N^{2}=N-$ morpholinyl; 13d $\mathrm{Ar}_{2}=2-\mathrm{CIPh}$;

13e $\mathrm{Ar}_{2}=4$-(2-oxopyrrolidin-1-yl)phenyl;

10c, 11c, 12c, 13f: $\mathrm{R}_{3} \mathrm{NR}_{4}=\mathrm{N}$-piperidinyl; 13f $\mathrm{Ar}_{2}=4-\mathrm{CIPh}$;

9c, 10d, 11d, 12d, 13g,h: $\mathrm{R}_{3} \mathrm{NR}_{4}=\mathrm{N}-\left(4-\right.$ methyl)piperidinyl; 13g $\mathrm{Ar}_{2}=3-\mathrm{MePh} ; \mathbf{1 3 h ~} \mathrm{Ar}_{2}=2-\mathrm{FPh}$

9d, 10e, 11e, 12e, 13i,j: $R_{3} N_{4}=N$-thiomorpholinyl; 13i $\mathrm{Ar}_{2}=3-\mathrm{FPh} ; 13 \mathrm{j} \mathrm{Ar}_{2}=2-\mathrm{Cl}-4-\mathrm{FPh}$

9e, 10f, 11f, 14b, 15d,e: $R_{3} N R_{4}=$ N-pyrrolidinyl; 15d $\mathrm{Ar}_{2}=3-\mathrm{CIPh} ; 15 \mathrm{e} \mathrm{Ar}_{2}=2 \mathrm{CIPh}$;

9f, 10g, 11g, 14c, 15f: $R_{3} N_{4}=N-1,2,3,4$-tetrahydroquinolinyl; 15f $\mathrm{Ar}_{2}=4-\mathrm{FPh}$;

Scheme 3. Synthesis of compounds $13 \mathrm{a}-\mathbf{j}$ and $15 \mathrm{a}-\mathrm{f}$. (i) Dioxane, $60{ }^{\circ} \mathrm{C}, 1 \mathrm{~h}$; (ii) $\mathrm{N}_{2} \mathrm{H}_{4}$, $i$-propanol, reflux, $4 \mathrm{~h}$; (iii) $\mathrm{CDI}$, dioxane, reflux, $8 \mathrm{~h}$; (iv) $\mathrm{K}_{2} \mathrm{CO}_{3}, \mathrm{DMF}, 100{ }^{\circ} \mathrm{C}, 2 \mathrm{~h}$; (v) $\mathrm{CS}_{2}$, triethylamine, DMF, $90^{\circ} \mathrm{C}, 6 \mathrm{~h}$; (vi) triethylamine, DMF, $80{ }^{\circ} \mathrm{C}, 2 \mathrm{~h}$.

Table 2. Compounds presented in Scheme 2.

\begin{tabular}{|c|c|c|c|c|}
\hline Compound & Position of $\mathrm{SO}_{2} \mathrm{R}$ & $\mathrm{Ar}_{1}$ & $\mathbf{R}_{1}$ & $\mathrm{Ar}_{2}$ \\
\hline $1 \mathrm{a}$ & $3-\mathrm{SO}_{2} \mathrm{Cl}$ & - & - & - \\
\hline $1 b$ & $5-\mathrm{SO}_{2} \mathrm{Cl}$ & - & - & - \\
\hline $2 a$ & - & 3,5-diFPh & - & - \\
\hline $2 b$ & - & 3,5-diMePh & - & - \\
\hline $2 c$ & - & 3-MePh & - & - \\
\hline $2 \mathrm{~d}$ & - & 4-MeOPh & - & - \\
\hline $2 e$ & - & 4-FPh & - & - \\
\hline $2 \mathrm{f}$ & - & 3-ClPh & - & - \\
\hline $2 \mathrm{~g}$ & - & 4-ClPh & - & - \\
\hline $3 a$ & $3-\mathrm{SO}_{2} \mathrm{Ar}_{1}$ & 3,5-diFPh & - & - \\
\hline $3 b$ & $3-\mathrm{SO}_{2} \mathrm{Ar}_{1}$ & 3,5-diMePh & - & - \\
\hline $3 c$ & $5-\mathrm{SO}_{2} \mathrm{Ar}_{1}$ & 3-MePh & - & - \\
\hline $3 d$ & $5-\mathrm{SO}_{2} \mathrm{Ar}_{1}$ & 4-MeOPh & - & - \\
\hline
\end{tabular}


Table 2. Cont.

\begin{tabular}{|c|c|c|c|c|}
\hline Compound & Position of $\mathrm{SO}_{2} \mathrm{R}$ & $\mathrm{Ar}_{1}$ & $\mathbf{R}_{1}$ & $\mathrm{Ar}_{2}$ \\
\hline $3 e$ & $5-\mathrm{SO}_{2} \mathrm{Ar}_{1}$ & 4-FPh & - & - \\
\hline $3 f$ & $5-\mathrm{SO}_{2} \mathrm{Ar}_{1}$ & 3-ClPh & - & - \\
\hline $3 g$ & $5-\mathrm{SO}_{2} \mathrm{Ar}_{1}$ & 4-ClPh & - & - \\
\hline $4 a$ & $3-\mathrm{SO}_{2} \mathrm{Ar}_{1}$ & 3,5-diFPh & - & - \\
\hline $4 b$ & $3-\mathrm{SO}_{2} \mathrm{Ar}_{1}$ & 3,5-diMePh & - & - \\
\hline $4 c$ & $5-\mathrm{SO}_{2} \mathrm{Ar}_{1}$ & 3-MePh & - & - \\
\hline $4 d$ & $5-\mathrm{SO}_{2} \mathrm{Ar}_{1}$ & 4-MeOPh & - & - \\
\hline $4 e$ & $5-\mathrm{SO}_{2} \mathrm{Ar}_{1}$ & 4-FPh & - & - \\
\hline $4 \mathrm{f}$ & $5-\mathrm{SO}_{2} \mathrm{Ar}_{1}$ & 3-ClPh & - & - \\
\hline $4 \mathrm{~g}$ & $5-\mathrm{SO}_{2} \mathrm{Ar}_{1}$ & 4-ClPh & - & - \\
\hline $5 a$ & - & - & $\mathrm{H}$ & - \\
\hline $5 b$ & - & - & $\mathrm{Me}$ & - \\
\hline $5 c$ & - & - & Et & - \\
\hline $6 a$ & $8-\mathrm{SO}_{2} \mathrm{Ar}_{1}$ & 3,5-diFPh & $\mathrm{H}$ & - \\
\hline $6 b$ & $8-\mathrm{SO}_{2} \mathrm{Ar}_{1}$ & 3,5-diMePh & $\mathrm{Me}$ & - \\
\hline $6 c$ & $6-\mathrm{SO}_{2} \mathrm{Ar}_{1}$ & 3-MePh & $\mathrm{Me}$ & - \\
\hline $6 d$ & 6- $\mathrm{SO}_{2} \mathrm{Ar}_{1}$ & 4-MeOPh & Et & - \\
\hline $6 e$ & 6- $\mathrm{SO}_{2} \mathrm{Ar}_{1}$ & 4-FPh & $\mathrm{Me}$ & - \\
\hline $6 f$ & $6-\mathrm{SO}_{2} \mathrm{Ar}_{1}$ & 3-ClPh & $\mathrm{Me}$ & - \\
\hline $6 \mathrm{~g}$ & 6- $\mathrm{SO}_{2} \mathrm{Ar}_{1}$ & 4-ClPh & $\mathrm{Me}$ & - \\
\hline $7 a$ & - & - & - & 3-ClPh \\
\hline $7 \mathrm{~b}$ & - & - & - & 2,5-diMePh \\
\hline $7 \mathrm{c}$ & - & - & - & $4-\mathrm{MeOPh}$ \\
\hline $7 d$ & - & - & - & 5-methoxycarbonyl-(furan-2-yl) \\
\hline $7 e$ & - & - & - & 3-FPh \\
\hline $7 f$ & - & - & - & 3-MePh \\
\hline $7 \mathrm{~g}$ & - & - & - & 2-FPh \\
\hline $7 \mathrm{~h}$ & - & - & - & $4-\mathrm{FPh}$ \\
\hline $8 a$ & $8-\mathrm{SO}_{2} \mathrm{Ar}_{1}$ & 3,5-diFPh & $\mathrm{H}$ & $3-\mathrm{ClPh}$ \\
\hline $8 b$ & $8-\mathrm{SO}_{2} \mathrm{Ar}_{1}$ & 3,5-diMePh & $\mathrm{Me}$ & 2,5-diMePh \\
\hline $8 c$ & $8-\mathrm{SO}_{2} \mathrm{Ar}_{1}$ & 3,5-diMePh & $\mathrm{Me}$ & 4-MeOPh \\
\hline $8 d$ & 6- $\mathrm{SO}_{2} \mathrm{Ar}_{1}$ & 3-MePh & $\mathrm{Me}$ & 5-methoxycarbonyl-(furan-2-yl) \\
\hline $8 \mathrm{e}$ & 6- $\mathrm{SO}_{2} \mathrm{Ar}_{1}$ & 4-MeOPh & Et & $3-\mathrm{FPh}$ \\
\hline $8 f$ & $6-\mathrm{SO}_{2} \mathrm{Ar}_{1}$ & 4-FPh & $\mathrm{Me}$ & 3-MePh \\
\hline $8 g$ & $6-\mathrm{SO}_{2} \mathrm{Ar}_{1}$ & $4-\mathrm{FPh}$ & $\mathrm{Me}$ & 3-ClPh \\
\hline $8 \mathrm{~h}$ & 6- $\mathrm{SO}_{2} \mathrm{Ar}_{1}$ & 3-ClPh & $\mathrm{Me}$ & 2-FPh \\
\hline $8 \mathbf{i}$ & $6-\mathrm{SO}_{2} \mathrm{Ar}_{1}$ & 4-ClPh & $\mathrm{Me}$ & 4-FPh \\
\hline
\end{tabular}

Table 3. Compounds presented in the Scheme 3.

\begin{tabular}{|c|c|c|c|}
\hline Compound & Position of $\mathrm{SO}_{2} \mathrm{R}$ & $\mathbf{R}_{3} \mathbf{N R}_{4}$ & $\mathrm{Ar}_{2}$ \\
\hline $1 \mathrm{a}$ & $3-\mathrm{SO}_{2} \mathrm{Cl}$ & - & - \\
\hline $1 b$ & $5-\mathrm{SO}_{2} \mathrm{Cl}$ & - & - \\
\hline $7 \mathbf{i}$ & - & - & benzo[d][1,3]dioxol-5-yl \\
\hline $7 \mathbf{j}$ & - & - & 3,5-diFPh \\
\hline $7 \mathbf{k}$ & - & - & 2-ClPh \\
\hline 71 & - & - & 4-(2-oxopyrrolidin-1-yl)phenyl \\
\hline $7 \mathrm{~m}$ & - & - & 4-ClPh \\
\hline $7 \mathrm{n}$ & - & - & 2-Cl-4-FPh \\
\hline 70 & - & - & 3-BrPh \\
\hline $7 p$ & - & - & 4-MePh \\
\hline $9 a$ & - & $N$-piperidinyl & - \\
\hline $9 b$ & - & $N$-morpholinyl & - \\
\hline $9 \mathrm{c}$ & - & $N$-(4-methyl)piperidinyl & - \\
\hline 9d & - & $\mathrm{N}$-thiomorpholinyl & - \\
\hline $9 e$ & - & $N$-pyrrolidinyl & - \\
\hline 9f & - & $N-1,2,3,4$-tetrahydroquinolinyl & - \\
\hline $10 a$ & $3-\mathrm{SO}_{2} \mathrm{NR}_{3} \mathrm{R}_{4}$ & $N$-piperidinyl & - \\
\hline
\end{tabular}


Table 3. Cont.

\begin{tabular}{|c|c|c|c|}
\hline Compound & Position of $\mathrm{SO}_{2} \mathrm{R}$ & $\mathbf{R}_{3} \mathbf{N R}_{4}$ & $\mathrm{Ar}_{2}$ \\
\hline $10 \mathrm{~b}$ & $3-\mathrm{SO}_{2} \mathrm{NR}_{3} \mathrm{R}_{4}$ & $N$-morpholinyl & - \\
\hline 10c & $5-\mathrm{SO}_{2} \mathrm{NR}_{3} \mathrm{R}_{4}$ & $N$-piperidinyl & - \\
\hline $10 \mathrm{~d}$ & $5-\mathrm{SO}_{2} \mathrm{NR}_{3} \mathrm{R}_{4}$ & $N$-(4-methyl)piperidinyl & - \\
\hline $10 \mathrm{e}$ & $3-\mathrm{SO}_{2} \mathrm{NR}_{3} \mathrm{R}_{4}$ & $N$-thiomorpholinyl & - \\
\hline $10 f$ & $3-\mathrm{SO}_{2} \mathrm{NR}_{3} \mathrm{R}_{4}$ & $N$-pyrrolidinyl & - \\
\hline $10 \mathrm{~g}$ & $3-\mathrm{SO}_{2} \mathrm{NR}_{3} \mathrm{R}_{4}$ & $N-1,2,3,4$-tetrahydroquinolinyl & - \\
\hline $11 \mathrm{a}$ & $3-\mathrm{SO}_{2} \mathrm{NR}_{3} \mathrm{R}_{4}$ & $N$-piperidinyl & - \\
\hline $11 b$ & $3-\mathrm{SO}_{2} \mathrm{NR}_{3} \mathrm{R}_{4}$ & $N$-morpholinyl & - \\
\hline 11c & $5-\mathrm{SO}_{2} \mathrm{NR}_{3} \mathrm{R}_{4}$ & $N$-piperidinyl & - \\
\hline 11d & $5-\mathrm{SO}_{2} \mathrm{NR}_{3} \mathrm{R}_{4}$ & $N$-(4-methyl)piperidinyl & - \\
\hline $11 \mathrm{e}$ & $3-\mathrm{SO}_{2} \mathrm{NR}_{3} \mathrm{R}_{4}$ & $\mathrm{~N}$-thiomorpholinyl & - \\
\hline $11 f$ & $3-\mathrm{SO}_{2} \mathrm{NR}_{3} \mathrm{R}_{4}$ & $N$-pyrrolidinyl & - \\
\hline $11 \mathrm{~g}$ & $3-\mathrm{SO}_{2} \mathrm{NR}_{3} \mathrm{R}_{4}$ & $N-1,2,3,4$-tetrahydroquinolinyl & - \\
\hline $12 \mathrm{a}$ & $8-\mathrm{SO}_{2} \mathrm{NR}_{3} \mathrm{R}_{4}$ & $N$-piperidinyl & - \\
\hline $12 b$ & $8-\mathrm{SO}_{2} \mathrm{NR}_{3} \mathrm{R}_{4}$ & $N$-morpholinyl & - \\
\hline $12 \mathrm{c}$ & $6-\mathrm{SO}_{2} \mathrm{NR}_{3} \mathrm{R}_{4}$ & $N$-piperidinyl & - \\
\hline $12 d$ & $6-\mathrm{SO}_{2} \mathrm{NR}_{3} \mathrm{R}_{4}$ & $N$-(4-methyl)piperidinyl & - \\
\hline $12 \mathrm{e}$ & $6-\mathrm{SO}_{2} \mathrm{NR}_{3} \mathrm{R}_{4}$ & $N$-thiomorpholinyl & - \\
\hline $13 a$ & $8-\mathrm{SO}_{2} \mathrm{NR}_{3} \mathrm{R}_{4}$ & $N$-piperidinyl & 3-ClPh \\
\hline $13 b$ & $8-\mathrm{SO}_{2} \mathrm{NR}_{3} \mathrm{R}_{4}$ & $N$-piperidinyl & benzo[d][1,3]dioxol-5-yl \\
\hline $13 \mathrm{c}$ & $8-\mathrm{SO}_{2} \mathrm{NR}_{3} \mathrm{R}_{4}$ & $N$-piperidinyl & 3,5-diFPh \\
\hline $13 d$ & $8-\mathrm{SO}_{2} \mathrm{NR}_{3} \mathrm{R}_{4}$ & $N$-morpholinyl & 2-ClPh \\
\hline $13 e$ & $8-\mathrm{SO}_{2} \mathrm{NR}_{3} \mathrm{R}_{4}$ & $N$-morpholinyl & 4-(2-oxopyrrolidin-1-yl)phenyl \\
\hline $13 \mathrm{f}$ & $6-\mathrm{SO}_{2} \mathrm{NR}_{3} \mathrm{R}_{4}$ & $N$-piperidinyl & $4-\mathrm{ClPh}$ \\
\hline $13 \mathrm{~g}$ & $6-\mathrm{SO}_{2} \mathrm{NR}_{3} \mathrm{R}_{4}$ & $N$-(4-methyl)piperidinyl & 3-MePh \\
\hline $13 \mathrm{~h}$ & $6-\mathrm{SO}_{2} \mathrm{NR}_{3} \mathrm{R}_{4}$ & $N$-(4-methyl)piperidinyl & 2-FPh \\
\hline $13 \mathbf{i}$ & $6-\mathrm{SO}_{2} \mathrm{NR}_{3} \mathrm{R}_{4}$ & $N$-thiomorpholinyl & 3-FPh \\
\hline $13 \mathbf{j}$ & $6-\mathrm{SO}_{2} \mathrm{NR}_{3} \mathrm{R}_{4}$ & $N$-thiomorpholinyl & 2-Cl-4-FPh \\
\hline $14 a$ & $8-\mathrm{SO}_{2} \mathrm{NR}_{3} \mathrm{R}_{4}$ & $N$-piperidinyl & - \\
\hline $14 b$ & $8-\mathrm{SO}_{2} \mathrm{NR}_{3} \mathrm{R}_{4}$ & $N$-pyrrolidinyl & - \\
\hline $14 \mathrm{c}$ & $8-\mathrm{SO}_{2} \mathrm{NR}_{3} \mathrm{R}_{4}$ & $N-1,2,3,4$-tetrahydroquinolinyl & - \\
\hline $15 a$ & $8-\mathrm{SO}_{2} \mathrm{NR}_{3} \mathrm{R}_{4}$ & $N$-piperidinyl & 4-MeOPh \\
\hline $15 b$ & $8-\mathrm{SO}_{2} \mathrm{NR}_{3} \mathrm{R}_{4}$ & $N$-piperidinyl & $3-\mathrm{BrPh}$ \\
\hline $15 \mathrm{c}$ & $8-\mathrm{SO}_{2} \mathrm{NR}_{3} \mathrm{R}_{4}$ & $N$-piperidinyl & 4-MePh \\
\hline $15 d$ & $8-\mathrm{SO}_{2} \mathrm{NR}_{3} \mathrm{R}_{4}$ & $N$-pyrrolidinyl & 3-ClPh \\
\hline $15 e$ & $8-\mathrm{SO}_{2} \mathrm{NR}_{3} \mathrm{R}_{4}$ & $N$-pyrrolidinyl & 2-ClPh \\
\hline $15 f$ & $8-\mathrm{SO}_{2} \mathrm{NR}_{3} \mathrm{R}_{4}$ & $N-1,2,3,4$-tetrahydroquinolinyl & $4-\mathrm{FPh}$ \\
\hline
\end{tabular}

All compounds were characterized by elemental analysis and ${ }^{1} \mathrm{H}-\mathrm{NMR}$ data. Target compounds $\mathbf{8 a}-\mathbf{i}, \mathbf{1 3} \mathbf{a}-\mathbf{j}$ and $\mathbf{1 5} \mathbf{a}-\mathbf{f}$ were additionally characterized by ${ }^{13} \mathrm{C}-\mathrm{NMR}$ and LC/MS data. (The NMR and LC/MS data may be accessed in the Supplementary Materials).

\subsection{Antiprotozoal Activity Assay}

The newly synthesized compounds were evaluated for their in vitro antiprotozoal inhibitory activity against the Plasmodium falciparum $2 / \mathrm{K}$ chloroquine-resistant strain by determining the concentration required to inhibit parasite development by $50 \%$ ( $\mathrm{IC}_{50}$ values). The protocols are described in the experimental section. The $\mathrm{IC}_{50}$ values and the cytotoxicity against human fibroblast of all the new compounds are listed in Table 4. 
Table 4. Integrated in vitro activity screening against Plasmodium falciparum. Results are expressed as $50 \%$ inhibitory concentration ( $\mathrm{IC}_{50}$-value).

\begin{tabular}{|c|c|c|c|}
\hline \multirow{2}{*}{$\begin{array}{l}\text { Compound } \\
\text { No }\end{array}$} & \multirow{2}{*}{ Structure of Compound } & \multicolumn{2}{|c|}{$\mathrm{IC}_{50}(\mu \mathrm{M})$} \\
\hline & & MRC-5 & P. falciparum \\
\hline $13 a$ & & $>64$ & 2.24 \\
\hline $8 \mathrm{e}$ & & 18.19 & 4.98 \\
\hline $8 \mathrm{i}$ & & $>64$ & 8.00 \\
\hline $13 g$ & & $>64$ & 8.00 \\
\hline $15 b$ & & $>64$ & 8.52 \\
\hline $13 b$ & & $>64$ & 8.93 \\
\hline $13 f$ & & $>64$ & 9.62 \\
\hline
\end{tabular}


Table 4. Cont.

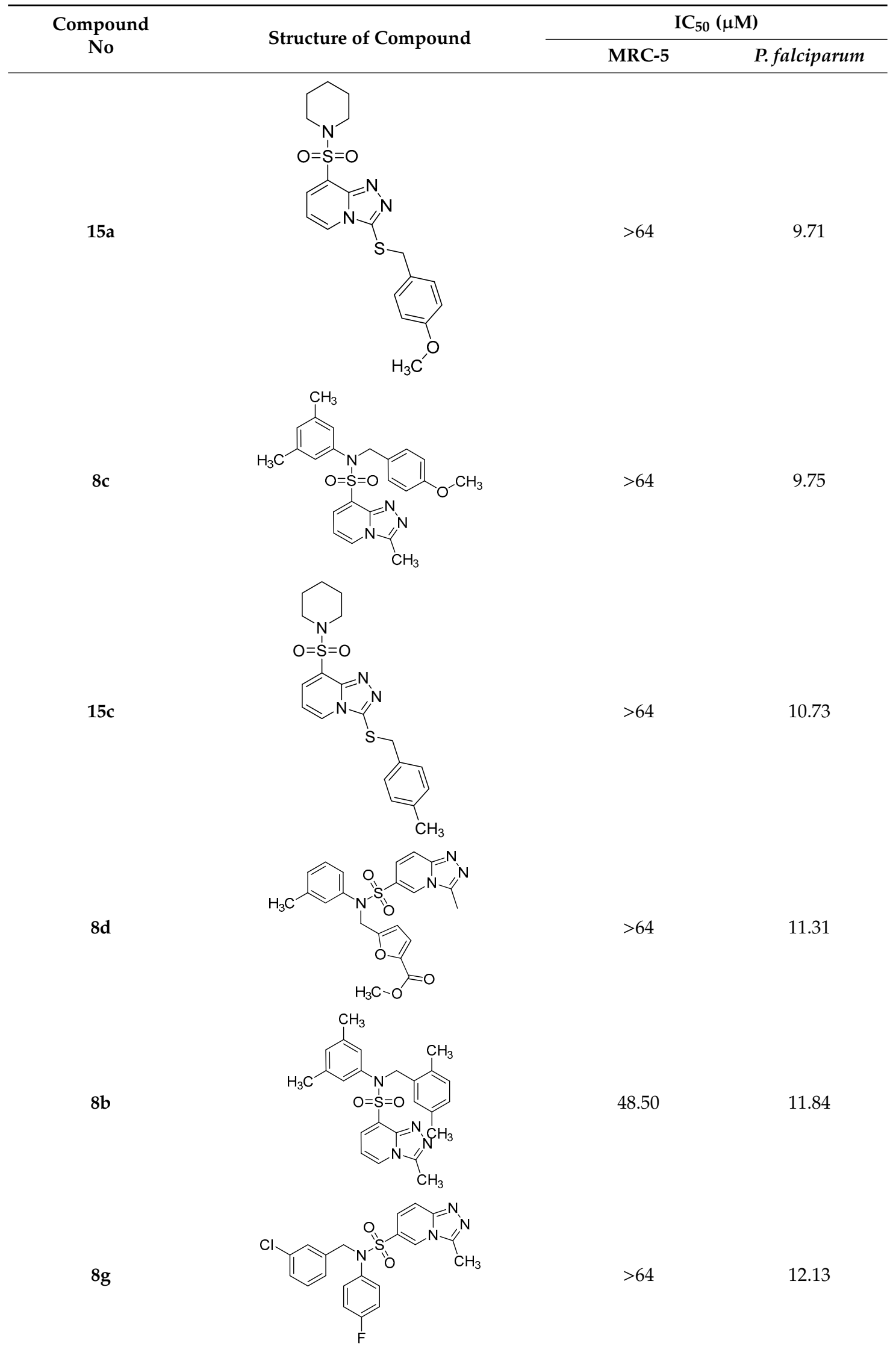


Table 4. Cont.

\begin{tabular}{|c|c|c|c|}
\hline \multirow{2}{*}{$\begin{array}{l}\text { Compound } \\
\text { No }\end{array}$} & \multirow{2}{*}{ Structure of Compound } & \multicolumn{2}{|c|}{$\mathrm{IC}_{50}(\mu \mathrm{M})$} \\
\hline & & MRC-5 & P. falciparum \\
\hline $13 d$ & & $>64$ & 13.59 \\
\hline $8 f$ & & $>64$ & 13.93 \\
\hline $13 e$ & & $>64$ & 27.86 \\
\hline $8 \mathrm{~h}$ & & $>64$ & 32.00 \\
\hline $8 a$ & & $>64$ & 40.32 \\
\hline $13 \mathrm{~h}$ & & $>64$ & 40.32 \\
\hline $13 c$ & & $>64$ & $>64$ \\
\hline $13 i$ & & $>64$ & $>64$ \\
\hline
\end{tabular}


Table 4. Cont.

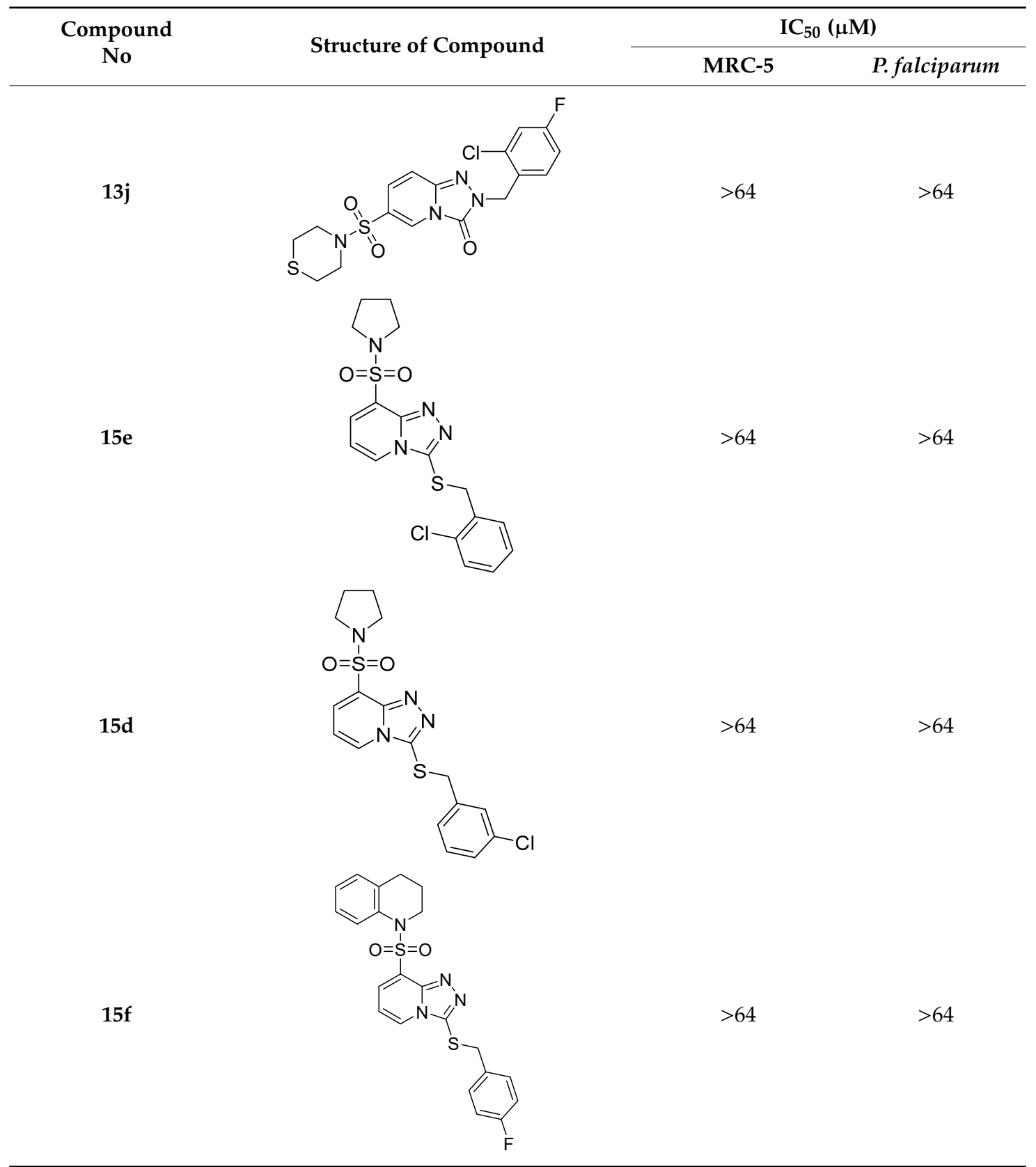

Chloroquine, a clinical candidate with an $\mathrm{IC}_{50}$ value of $0.02 \mu \mathrm{M}$, was used as a reference compound. Two of the 25 compounds were active against Plasmodium falciparum 2/K chloroquine-resistant strain at a concentration of $4.98 \mu \mathrm{M}$ for $6 \mathrm{e}$ and $2.24 \mu \mathrm{M}$ for $10 \mathrm{a}$. Seven compounds showed an inhibitory concentration ranging from 8 to $10 \mu \mathrm{M}$, and six compounds showed an inhibitory concentration ranging from 10 to $14 \mu \mathrm{M}$.

Two of the 25 tested samples showed cytotoxicity against MRC- 5 cells at a concentration of $\mathrm{IC}_{50}=$ $48.50 \mu \mathrm{g} / \mathrm{mL}$ for compound $8 \mathrm{~b}$ and $18.19 \mu \mathrm{g} / \mathrm{mL}$ for compound $8 \mathrm{e}$. At the same time, the 23 other tested samples did not show cytotoxicity against MRC-5 cells $\left(\mathrm{IC}_{50}>64 \mu \mathrm{g} / \mathrm{mL}\right.$ ), resulting in a high selectivity.

The drug-like properties of all compounds including the two main active compounds 13a and $8 \mathrm{e}$, according to the Lipinski Rule of Five, are summarized in Table 5. Based on these values, we can confirm that compounds $13 \mathrm{a}$ and 8e obey the Lipinski Rule of Five, which states that, for a good absorption and permeation, compounds should have a MW less than 500 Da, no more than 5 HBDs, 
10 HBAs, LogP value (partition coefficient between octanol and water) from 2 to 5 and a TPSA less than $140 \AA^{2}$ [39-41]. Based on the practical data, the compounds 8e and 13a are moderately soluble in DMSO/Water.

Table 5. Predicted pharmacokinetics of the compounds 13a and 8e.

\begin{tabular}{ccccccccc}
\hline \multirow{2}{*}{ Compound } & \multirow{2}{*}{ GIA $^{\mathbf{1}}$} & \multirow{2}{*}{ BBBP $^{2}$} & \multirow{2}{*}{ Pgp $^{3}$ Substrate } & \multicolumn{5}{c}{ CYP450 Inhibition } \\
\cline { 5 - 8 } & & & CYP1A2 & CYP2C19 & CYP2C9 & CYP2D6 & CYP3A4 \\
\hline 13a & High & No & No & No & Yes & Yes & No & No \\
8e & High & No & Yes & No & Yes & Yes & No & Yes \\
\hline \multicolumn{3}{r}{${ }^{1}$ GIA $=$ gastrointestinal absorption; ${ }^{2}$ BBBP $=$ blood brain barrier permeant; ${ }^{3}$ Pgp $=$ P-glycoprotein. }
\end{tabular}

In addition, in silico ADMET parameters, such as gastrointestinal absorption, P-glycoprotein substrate, blood brain barrier (BBB) permeability and CYP450 inhibition were predicted using Swiss-ADME [42].

The ability of active compounds to pass the blood-brain barrier is absent, with this being correlated with a reduced risk of developing side effects in the central nervous system upon administration. Our active compounds have no ability to pass the BBB. P-glycoprotein (Pgp) is a plasma membrane protein, which acts as a localized drug transport mechanism, actively exporting drugs out of the cell. Being a substrate to Pgp, compounds can generate a lot of drug-drug interactions and seriously modify the bioavailability and safety of a certain drug [43]. Compound 13a does not seem to be a substrate for Pgp, while 8e seems to be a substrate. A high gastrointestinal absorption was also predicted for active compounds. Moreover, the studied compounds act as non-inhibitors of CYP1A2, CYP2D6, CYP3A4, so drug-drug interactions with compounds that are metabolized by this isoform of CYP450 superfamily are less likely to appear.

\section{Materials and Methods}

\subsection{Pharmacophore Model Generation, Virtual Screening and Molecular Docking}

Pharmacophore models are often used together with other methods to further increase the number of active molecules in the hit list via the application of a consensus approach [44]. In the present work, a combination of pharmacophore-based and docking approaches was used. The pharmacophore model was constructed using LigandScout software [45], which contains all the chemical features' information, such as hydrogen bond donors, hydrogen bond acceptors, and hydrophobic residues within the binding site sphere of the receptor $[37,44]$. The crystal structure of FP-2 bound to the epoxysuccinate E64 inhibitor with high resolution was downloaded from the Protein Data Bank [46] (PDB entry: 3bpf). The structure of the protein was imported into LigandScout software for structural alignment with the protein preparation wizard to ensure its structural correctness. Preparation of protein: the addition of hydrogens and removal of water molecules were done with LigandScout default settings. The respective crystal ligands of E64 in every of four chains (A, B, C, D) were checked to ensure they were correctly depicted, for example, whether bond orders are correct and were subjected to energy minimization. After that, ligands were re-docked by AutoDock Vina [47] into the active sites of the target protein (3bpf) to validate the docking protocol. Chain D was selected for further studies because it had the lowest RMSD value. The structure-based method was used to construct the 3D pharmacophore model.

The generated 3D pharmacophore model was used as a 3D search query for retrieving potent hit molecules from our in-house database. The AutoDock Vina software was used for molecular docking simulations and LigandScout with Biovia Discovery Studio Visualizer for visualizing the obtained results.

\subsection{Chemistry. General Information}

All NMR spectra were recorded on a Varian MR-400 spectrometer (Varian, Inc., Walnut Creek, CA, USA) with standard pulse sequences operating at 200, 300 or $400 \mathrm{MHz}$ for ${ }^{1} \mathrm{H}-\mathrm{NMR}$, and $75 \mathrm{MHz}$ or 
$100 \mathrm{MHz}$ for ${ }^{13} \mathrm{C}-\mathrm{NMR}$. For all NMR spectra, DMSO-d6 was used as a solvent. Chemical shift values are referenced to residual protons $(\delta 2.49 \mathrm{ppm})$ and carbons $(\delta 39.6 \mathrm{ppm})$ of the solvent as an internal standard. Elemental analysis was performed on EuroEA-3000 CHNS-O Analyzer (Euro Vector, Milan, Italy). Melting points were measured with a Buchi B-520 melting point apparatus (Buchi AG, Flawil, Switzerland). LC/MS spectra were recorded with ELSD Alltech 3300 liquid chromatograph (Buchi AG, Flawil, Switzerland) equipped with a UV detector $\left(\lambda_{\max } 254 \mathrm{~nm}\right)$, API-150EX mass-spectrometer and using a Zorbax SB-C18 column, Phenomenex $(100 \times 4 \mathrm{~mm})$ Rapid Resolution HT Cartrige $4.6 \times 30 \mathrm{~mm}$, 1.8-Micron. Elution started with $0.1 \mathrm{M}$ solution of $\mathrm{HCOOH}$ in water and ended with $0.1 \mathrm{M}$ solution of $\mathrm{HCOOH}$ in acetonitrile used a linear gradient at a flow rate of $0.15 \mathrm{~mL} / \mathrm{min}$ and an analysis cycle time of $25 \mathrm{~min}$. UV/Vis spectra of solutions in $\mathrm{CH} 3 \mathrm{CN}$ were recorded on a Specord 200 spectrometer (Analytik Jena AG, Jena, Germany). IR spectra in $\mathrm{KBr}$ pellets were recorded on a Bruker Vertex 70 FTIR spectrometer (Bruker Optik GmbH, Ettlingen, Germany). The purity of compounds was checked by thin layer chromatography, which was performed on Silufol UV254 aluminum plates precoated with silica gel with EtOAc:Hex (1:2, 1:4), EtOAc, EtOAc:MeOH (9:1) as eluents.

Starting 2-chloropyridinesulfonyl chlorides $\mathbf{1} \mathbf{a}, \mathbf{b}$ were purchased from Life Chemicals (Kyiv, Ukraine). Anilines $\mathbf{2 a -} \mathbf{g}$, benzyl chlorides $\mathbf{7 a -} \mathbf{p}$, secondary amines $\mathbf{9 a}-\mathbf{f}$, other reagents and solvents are commercially available, were reagent grade and were used without further purification. Silica gel $(40-60 \mu \mathrm{m})$ from Merck was used for column chromatography.

\subsection{General Procedures for the Synthesis}

\subsubsection{Synthesis of 2-Chloro- $N$-(aryl)Pyridinesulfonamides 3a-g. General Procedure A}

Primary aniline $2 \mathbf{a}-\mathbf{g}(0.12 \mathrm{~mol})$ and triethylamine $(15 \mathrm{~mL}, 0.12 \mathrm{~mol})$ were added to a stirred solution of sulfonyl chloride $1 \mathrm{a}, \mathrm{b}(21.2 \mathrm{~g}, 0.1 \mathrm{~mol})$ in dry dioxane $(100 \mathrm{~mL})$ for $5 \mathrm{~min}$ at room temperature. The reaction mixture was heated at $60^{\circ} \mathrm{C}$ for $3 \mathrm{~h}$. After cooling, the reaction mixture was diluted with water $(500 \mathrm{~mL})$. The precipitate that formed was filtered and recrystallized from $i$-propanol. Yields of 2-chloro- $N$-(aryl)pyridinesulfonamides 3a-g were 70-82\%.

2-Chloro-N-(3,5-difluorophenyl)pyridine-3-sulfonamide (3a). According to General Procedure A, 2-chloropyridine-3-sulfonyl chloride $\mathbf{1 a}(21.2 \mathrm{~g}, 0.1 \mathrm{~mol})$ and 3,5-difluoroaniline $\mathbf{2 a}(15.5 \mathrm{~g}, 0.12 \mathrm{~mol})$ yielded 2-chloro- $\mathrm{N}$-(3,5-difluorophenyl)pyridine-3-sulfonamide $3 \mathrm{a}(21.9 \mathrm{~g}, 72 \%)$, as a white solid, m.p. 196-198 ${ }^{\circ} \mathrm{C} .{ }^{1} \mathrm{H}-\mathrm{NMR}$ spectrum $\delta$, ppm $(J, \mathrm{~Hz})$ : 6.31-6.37 (m, 1H, Ph H-4), 6.55 (dd, J = 11.4, $J=4.6,2 \mathrm{H}, \mathrm{Ph} \mathrm{H}-2,6), 7.63(\mathrm{dd}, J=8.4, J=6.8,1 \mathrm{H}, \mathrm{H}-5), 8.04(\mathrm{dd}, J=8.4, J=1.5,1 \mathrm{H}, \mathrm{H}-6), 8.73(\mathrm{dd}$, $J=6.8, J=1.5,1 \mathrm{H}, \mathrm{H}-4), 10.20(\mathrm{~s}, 1 \mathrm{H}, \mathrm{NH})$. Anal. calcd. for $\mathrm{C}_{11} \mathrm{H}_{7} \mathrm{ClF}_{2} \mathrm{~N}_{2} \mathrm{O}_{2} \mathrm{~S} \%$ : C 43.36; $\mathrm{H} 2.32 ; \mathrm{N}$ 9.19; S 10.52. Found, \%: C 43.22; H 2.31; N 9.23; S 10.49.

2-Chloro-N-(3,5-dimethylphenyl)pyridine-3-sulfonamide (3b). According to General Procedure A, 2-chloropyridine-3-sulfonyl chloride $\mathbf{1 a}(21.2 \mathrm{~g}, 0.1 \mathrm{~mol})$ and 3,5-dimethylaniline $\mathbf{2 b}$ (14.5 g, $0.12 \mathrm{~mol})$ yielded 2-chloro- $N$-(3,5-dimethylphenyl)pyridine-3-sulfonamide $3 \mathbf{b}(24.0 \mathrm{~g}, 81 \%)$, as a white solid, m.p. $174-176{ }^{\circ} \mathrm{C} .{ }^{1} \mathrm{H}-\mathrm{NMR}$ spectrum $\delta, \mathrm{ppm}(\mathrm{J}, \mathrm{Hz}): 2.24\left(\mathrm{~s}, 6 \mathrm{H}, 2 \mathrm{CH}_{3}\right), 6.50(\mathrm{~s}, 1 \mathrm{H}, \mathrm{Ph} \mathrm{H}-4), 6.71(\mathrm{~s}, 2 \mathrm{H}$, Ph H-2,6), 7.64 (dd, $J=8.4, J=6.8,1 \mathrm{H}, \mathrm{H}-5), 8.04$ (dd, $J=8.4, J=1.5,1 \mathrm{H}, \mathrm{H}-6), 8.73(\mathrm{dd}, J=6.8, J=1.5$, $1 \mathrm{H}, \mathrm{H}-4), 10.20$ (s, $1 \mathrm{H}, \mathrm{NH}$ ). Anal. calcd. for $\mathrm{C}_{13} \mathrm{H}_{13} \mathrm{ClN}_{2} \mathrm{O}_{2} \mathrm{~S} \%$ : $\mathrm{C} 52.61 ; \mathrm{H} 4.42 ; \mathrm{N}$ 9.44; $\mathrm{S} 10.80$. Found, \%: C 52.78; H 4.41; N 9.47; S 10.76 .

2-Chloro-N-(3-methylphenyl)pyridine-5-sulfonamide (3c). According to General Procedure A, 2-chloropyridine- 5 -sulfonyl chloride $1 \mathbf{b}(21.2 \mathrm{~g}, 0.1 \mathrm{~mol})$ and 3-methylaniline $2 \mathrm{c}(12.8 \mathrm{~g}, 0.12 \mathrm{~mol})$ yielded 2-chloro- $N$-(3-methylphenyl)pyridine-5-sulfonamide $3 \mathrm{c}(21.5 \mathrm{~g}, 76 \%)$, as a white solid, m.p. $171-173{ }^{\circ} \mathrm{C}$. ${ }^{1} \mathrm{H}-\mathrm{NMR}$ spectrum $\delta, \operatorname{ppm}(\mathrm{J}, \mathrm{Hz}): 2.20\left(\mathrm{~s}, 3 \mathrm{H}, \mathrm{CH}_{3}\right), 6.82-6.98(\mathrm{~m}, 3 \mathrm{H}, \mathrm{Ar} \mathrm{H}), 7.12(\mathrm{t}, J=7.6,1 \mathrm{H}, \mathrm{Ph} \mathrm{H}-5)$, $7.71(\mathrm{~d}, J=8.0,1 \mathrm{H}, \mathrm{H}-3), 8.11(\mathrm{dd}, J=8.0, J=2.2,1 \mathrm{H}, \mathrm{H}-4), 8.70(\mathrm{~d}, J=2.2,1 \mathrm{H}, \mathrm{H}-6), 10.42(\mathrm{~s}, 1 \mathrm{H}, \mathrm{NH})$. Anal. calcd. for $\mathrm{C}_{12} \mathrm{H}_{11} \mathrm{ClN}_{2} \mathrm{O}_{2} \mathrm{~S}$ \%: C 50.98; $\mathrm{H} 3.92 ; \mathrm{N}$ 9.91; $\mathrm{S} 11.34$. Found, \%: C 51.16; H 3.93; N 9.88; S 11.29. 
2-Chloro-N-(4-methoxyphenyl)pyridine-5-sulfonamide (3d). According to General Procedure A, 2-chloropyridine-5-sulfonyl chloride $\mathbf{1 b}$ (21.2 g, $0.1 \mathrm{~mol})$ and 4-methoxyaniline $2 \mathrm{~d}$ (14.8 g, $0.12 \mathrm{~mol})$ yielded 2-chloro- $N$-(4-methoxyphenyl)pyridine-5-sulfonamide $3 \mathrm{~d}(24.5 \mathrm{~g}, 82 \%)$, as a white solid, m.p. $182-183{ }^{\circ} \mathrm{C} .{ }^{1} \mathrm{H}-\mathrm{NMR}$ spectrum $\delta, \operatorname{ppm}(\mathrm{J}, \mathrm{Hz}): 3.67\left(\mathrm{~s}, 3 \mathrm{H}, \mathrm{OCH}_{3}\right), 6.80(\mathrm{~d}, J=8.0,2 \mathrm{H}, \mathrm{Ph} \mathrm{H}-3,5)$, $6.98(\mathrm{~d}, J=8.0,2 \mathrm{H}, \mathrm{Ph} \mathrm{H}-2,6), 7.70(\mathrm{~d}, J=8.0,1 \mathrm{H}, \mathrm{H}-3), 8.11(\mathrm{dd}, J=8.0, J=2.2,1 \mathrm{H}, \mathrm{H}-4), 8.54(\mathrm{~d}, J=2.2$, $1 \mathrm{H}, \mathrm{H}-6), 10.19$ (s, $1 \mathrm{H}, \mathrm{NH})$. Anal. calcd. for $\mathrm{C}_{12} \mathrm{H}_{11} \mathrm{ClN}_{2} \mathrm{O}_{3} \mathrm{~S} \%$ : C 48.25; $\mathrm{H} 3.71 ; \mathrm{N} 9.38 ; \mathrm{S}$ 10.73. Found, \%: C 48.06; H 3.73; N 9.41; S 10.69.

2-Chloro-N-(4-fluorophenyl)pyridine-5-sulfonamide (3e). According to General Procedure A, 2-chloropyridine-5-sulfonyl chloride $\mathbf{1 b}$ (21.2 g, $0.1 \mathrm{~mol})$ and 4-fluoroaniline $2 \mathrm{e}$ (13.3 g, $0.12 \mathrm{~mol})$ yielded 2-chloro- $N$-(4-fluorophenyl)pyridine-5-sulfonamide $3 \mathbf{e}(20.9 \mathrm{~g}, 73 \%)$, as a white solid, m.p. $202-203{ }^{\circ} \mathrm{C}$. ${ }^{1} \mathrm{H}-\mathrm{NMR}$ spectrum $\delta$, ppm $(\mathrm{J}, \mathrm{Hz}): 7.02-7.18$ (m, 4H, Ar H), 7.72 (d, J = 8.0, 1H, H-3), 8.07 (dd, $J=8.0$, $J=2.2,1 \mathrm{H}, \mathrm{H}-4), 8.63(\mathrm{~d}, J=2.2,1 \mathrm{H}, \mathrm{H}-6), 10.48$ (br. s, $1 \mathrm{H}, \mathrm{NH})$. Anal. calcd. for $\mathrm{C}_{11} \mathrm{H}_{8} \mathrm{ClFN}_{2} \mathrm{O}_{2} \mathrm{~S} \%$ : C 46.08; H 2.81; N 9.77; S 11.18. Found, \%: C 45.92; H 2.82; N 9.80; S 11.22.

2-Chloro-N-(3-chlorophenyl)pyridine-5-sulfonamide (3f). According to General Procedure A, 2-chloropyridine-5-sulfonyl chloride $\mathbf{1 b}$ (21.2 g, $0.1 \mathrm{~mol})$ and 3-chloroaniline $\mathbf{2 f}$ (15.3 g, $0.12 \mathrm{~mol})$ yielded 2-chloro-N-(3-chlorophenyl)pyridine-5-sulfonamide $3 f\left(21.2\right.$ g, 70\%), as a white solid, m.p. $191-193{ }^{\circ} \mathrm{C}$. ${ }^{1} \mathrm{H}-\mathrm{NMR}$ spectrum $\delta, \operatorname{ppm}(\mathrm{J}, \mathrm{Hz}): 7.02-7.18(\mathrm{~m}, 3 \mathrm{H}, \mathrm{Ar} \mathrm{H}), 7.28(\mathrm{t}, J=7.6,1 \mathrm{H}, \mathrm{Ph} \mathrm{H}-5), 7.72(\mathrm{~d}, J=8.0$, $1 \mathrm{H}, \mathrm{H}-3), 8.12$ (dd, $J=8.0, J=2.2,1 \mathrm{H}, \mathrm{H}-4), 8.74$ (d, $J=2.2,1 \mathrm{H}, \mathrm{H}-6), 10.80$ (br. s, $1 \mathrm{H}, \mathrm{NH})$. Anal. calcd. for $\mathrm{C}_{11} \mathrm{H}_{8} \mathrm{Cl}_{2} \mathrm{~N}_{2} \mathrm{O}_{2} \mathrm{~S}$ \%: C 43.58; $\mathrm{H}$ 2.66; N 9.24; $\mathrm{S}$ 10.58. Found, \%: C 43.42; H 2.65; N 9.20; S 10.62.

2-Chloro-N-(4-chlorophenyl)pyridine-5-sulfonamide (3g). According to General Procedure A, 2-chloropyridine-5-sulfonyl chloride $\mathbf{1 b}$ (21.2 g, $0.1 \mathrm{~mol})$ and 4-chloroaniline $2 \mathrm{~g}$ (15.3 g, $0.12 \mathrm{~mol})$ yielded 2-chloro- $N$-(4-chlorophenyl)pyridine-5-sulfonamide $3 \mathrm{~g}$ (21.2 g, 70\%), as a white solid, m.p. $207-209{ }^{\circ} \mathrm{C}$. ${ }^{1} \mathrm{H}-\mathrm{NMR}$ spectrum $\delta, \operatorname{ppm}(J, \mathrm{~Hz}): 7.11(\mathrm{~d}, J=8.0,2 \mathrm{H}, \mathrm{Ph} \mathrm{H}-3,5), 7.32(\mathrm{~d}, J=8.0,2 \mathrm{H}, \mathrm{Ph} \mathrm{H}-2,6)$, $7.71(\mathrm{~d}, J=8.0,1 \mathrm{H}, \mathrm{H}-3), 8.09(\mathrm{dd}, J=8.0, J=2.2,1 \mathrm{H}, \mathrm{H}-4), 8.70(\mathrm{~d}, J=2.2,1 \mathrm{H}, \mathrm{H}-6), 10.70(\mathrm{~s}, 1 \mathrm{H}, \mathrm{NH})$. Anal. calcd. for $\mathrm{C}_{11} \mathrm{H}_{8} \mathrm{Cl}_{2} \mathrm{~N}_{2} \mathrm{O}_{2} \mathrm{~S}$ \%: C 43.58; $\mathrm{H}$ 2.66; N 9.24; $\mathrm{S} 10.58$. Found, \%: C 43.65; H 2.67; N 9.22; S 10.56.

\subsubsection{Synthesis of $N$-(aryl)-2-Hydrazinylpyridinesulfonamides $\mathbf{4 a - g}$. General Procedure B}

The corresponding 2-chloro- $N$-(aryl)pyridinesulfonamide $\mathbf{3 a - g}$ (50 mmol) was added to a solution of hydrazine hydrate $(13 \mathrm{~mL}, 200 \mathrm{mmol})$ in $i$-propanol $(50 \mathrm{~mL})$. The reaction mixture was refluxed for $4 \mathrm{~h}$. After cooling, the reaction mixture was diluted with water $(200 \mathrm{~mL})$. The precipitate that formed was filtered and recrystallized from $i$-propanol. Yields of $N$-(aryl)-2-hydrazinylpyridinesulfonamides 4a-g were $84-91 \%$.

N-(3,5-difluorophenyl)-2-hydrazinylpyridine-3-sulfonamide (4a). According to General Procedure B, 2-chloro- $N$-(3,5-difluorophenyl)pyridine-3-sulfonamide 3a (15.2 g, $50 \mathrm{mmol})$ yielded $N$-(3,5difluorophenyl)-2-hydrazinylpyridine-3-sulfonamide $4 \mathrm{a}(13.1 \mathrm{~g}, 87 \%)$, as a white solid, m.p. $214-216$ ${ }^{\circ} \mathrm{C} .{ }^{1} \mathrm{H}-\mathrm{NMR}$ spectrum $\delta, \operatorname{ppm}(\mathrm{J}, \mathrm{Hz}): 4.49$ (br. s, 2H, NH $), 6.31-6.37$ (m, 1H, Ph H-4), 7.10 (d, $J=6.6$, 2H, Ph H-2,6), 7.40 (dd, $J=8.4, J=6.8,1 \mathrm{H}, \mathrm{H}-5), 7.95(\mathrm{dd}, J=8.4, J=1.5,1 \mathrm{H}, \mathrm{H}-6), 8.25(\mathrm{dd}, J=6.8$, $J=1.5,1 \mathrm{H}, \mathrm{H}-4), 8.80$ (br. s, $1 \mathrm{H}, \mathrm{NH}), 10.20$ (s, $\left.1 \mathrm{H}, \mathrm{SO}_{2} \mathrm{NH}\right)$. Anal. calcd. for $\mathrm{C}_{11} \mathrm{H}_{10} \mathrm{~F}_{2} \mathrm{~N}_{4} \mathrm{O}_{2} \mathrm{~S} \%$ : C 44.00; H 3.36; N 18.66; S 10.68. Found, \%: C 43.87; H 3.37; N 18.73; S 10.65.

N-(3,5-dimethylphenyl)-2-hydrazinylpyridine-3-sulfonamide (4b). According to General Procedure B, 2-chloro- $N$-(3,5-dimethylphenyl)pyridine-3-sulfonamide $3 \mathrm{~b}$ (14.8 g, $50 \mathrm{mmol}$ ) yielded $N$-(3,5dimethylphenyl)-2-hydrazinylpyridine-3-sulfonamide $4 \mathrm{~b}$ (12.4 g, 85\%), as a white solid, m.p. 201-203 ${ }^{\circ} \mathrm{C} .{ }^{1} \mathrm{H}-\mathrm{NMR}$ spectrum $\delta$, ppm $(\mathrm{J}, \mathrm{Hz}): 2.24$ (s, 6H, $\left.2 \mathrm{CH}_{3}\right), 4.59$ (br. s, 2H, $\left.\mathrm{NH}_{2}\right), 6.50$ (s, 1H, Ph H-4), $6.66(\mathrm{dd}, J=8.4, J=6.8,1 \mathrm{H}, \mathrm{H}-5), 6.71$ (s, 2H, Ph H-2,6), $7.50(\mathrm{dd}, J=6.8, J=1.5,1 \mathrm{H}, \mathrm{H}-4), 7.87$ (dd, 
$J=8.4, J=1.5,1 \mathrm{H}, \mathrm{H}-6), 8.46$ (br. s, $1 \mathrm{H}, \mathrm{NH}), 9.75\left(\mathrm{~s}, 1 \mathrm{H}, \mathrm{SO}_{2} \mathrm{NH}\right)$. Anal. calcd. for $\mathrm{C}_{13} \mathrm{H}_{16} \mathrm{~N}_{4} \mathrm{O}_{2} \mathrm{~S} \%$ : C 53.41; H 5.52; N 19.16; S 10.97. Found, \%: C 53.26; H 5.54; N 19.24; S 11.01.

2-Hydrazinyl-N-(3-methylphenyl)pyridine-5-sulfonamide (4c). According to General Procedure B, 2-chloro- $N$-(3-methylphenyl)pyridine-5-sulfonamide $3 \mathrm{c}(14.1 \mathrm{~g}, 50 \mathrm{mmol})$ yielded 2-hydrazinyl$\mathrm{N}$-(3-methylphenyl)pyridine-5-sulfonamide $4 \mathrm{c}(11.7 \mathrm{~g}, 84 \%)$, as a white solid, m.p. $187-189{ }^{\circ} \mathrm{C}$. ${ }^{1} \mathrm{H}-\mathrm{NMR}$ spectrum $\delta$, ppm $(\mathrm{J}, \mathrm{Hz}): 2.18\left(\mathrm{~s}, 3 \mathrm{H}, \mathrm{CH}_{3}\right), 4.35$ (br. s, $\left.2 \mathrm{H}, \mathrm{NH}_{2}\right), 6.67(\mathrm{~d}, J=8.0,1 \mathrm{H}, \mathrm{H}-3)$, 6.78-6.90 (m, 3H, Ar H), 7.09 (t, J = 7.6, 1H, Ph H-5), 7.62 (dd, J = 8.0, J = 2.2, 1H, H-4), 8.21 (s, 1H, H-6), 8.41 (br. s, $1 \mathrm{H}, \mathrm{NH}$ ), 9.90 (br. s, $1 \mathrm{H}, \mathrm{SO}_{2} \mathrm{NH}$ ). Anal. calcd. for $\mathrm{C}_{12} \mathrm{H}_{14} \mathrm{~N}_{4} \mathrm{O}_{2} \mathrm{~S}$ \%: C 51.78; $\mathrm{H}$ 5.07; N 20.13; S 11.52. Found, \%: C 51.96; H 5.05; N 20.19; S 11.47.

2-Hydrazinyl-N-(4-methoxyphenyl)pyridine-5-sulfonamide (4d). According to General Procedure B, 2-chloro- $N$-(4-methoxyphenyl)pyridine-5-sulfonamide 3d (14.9 g, $50 \mathrm{mmol})$ yielded 2-hydrazinyl$\mathrm{N}$-(4-methoxyphenyl)pyridine-5-sulfonamide $4 \mathrm{~d}\left(13.1 \mathrm{~g}\right.$, 89\%), as a white solid, m.p. $198-200{ }^{\circ} \mathrm{C}$. 1H-NMR spectrum $\delta$, ppm $(J, \mathrm{~Hz}): 3.67\left(\mathrm{~s}, 3 \mathrm{H}, \mathrm{OCH}_{3}\right), 4.35$ (br. s, $\left.2 \mathrm{H}, \mathrm{NH}_{2}\right), 6.67(\mathrm{~d}, J=8.0,1 \mathrm{H}, \mathrm{H}-3)$, $6.79(\mathrm{~d}, J=8.0,2 \mathrm{H}, \mathrm{Ph} \mathrm{H}-3,5), 6.97$ (d, $J=8.0,2 \mathrm{H}, \mathrm{Ph} \mathrm{H}-2,6), 7.57(\mathrm{dd}, J=8.0, J=2.2,1 \mathrm{H}, \mathrm{H}-4), 8.09$ $(\mathrm{d}, J=2.2,1 \mathrm{H}, \mathrm{H}-6), 8.36$ (br. s, $1 \mathrm{H}, \mathrm{NH}), 9.54$ (br. s, $1 \mathrm{H}, \mathrm{SO}_{2} \mathrm{NH}$ ). Anal. calcd. for $\mathrm{C}_{12} \mathrm{H}_{14} \mathrm{~N}_{4} \mathrm{O}_{3} \mathrm{~S} \%$ : C 48.97; H 4.79; N 19.04; S 10.89. Found, \%: C 49.14; H 4.80; N 18.98; S 10.93.

N-(4-fluorophenyl)-2-hydrazinylpyridine-5-sulfonamide (4e). According to General Procedure B, 2-chloro- $\mathrm{N}$-(4-fluorophenyl)pyridine-5-sulfonamide $3 \mathbf{e}$ ( $14.3 \mathrm{~g}$, $50 \mathrm{mmol}$ ) yielded $\mathrm{N}$-(4-fluorophenyl)2-hydrazinylpyridine-5-sulfonamide 4 e $(12.8 \mathrm{~g}, 91 \%)$, as a white solid, m.p. $219-221^{\circ} \mathrm{C}$. $1 \mathrm{H}-\mathrm{NMR}$ spectrum $\delta$, ppm (J, Hz): 4.35 (br. s, $\left.2 \mathrm{H}, \mathrm{NH}_{2}\right), 6.67$ (d, $\left.J=8.0,1 \mathrm{H}, \mathrm{H}-3\right), 7.02-7.12(\mathrm{~m}, 4 \mathrm{H}, \mathrm{Ar} \mathrm{H})$, $7.57(\mathrm{dd}, J=8.0, J=2.2,1 \mathrm{H}, \mathrm{H}-4), 8.17(\mathrm{~d}, J=2.2,1 \mathrm{H}, \mathrm{H}-6), 8.43$ (br. s, $1 \mathrm{H}, \mathrm{NH}), 9.86$ (br. s, $\left.1 \mathrm{H}, \mathrm{SO}_{2} \mathrm{NH}\right)$. Anal. calcd. for $\mathrm{C}_{11} \mathrm{H}_{11} \mathrm{FN}_{4} \mathrm{O}_{2} \mathrm{~S}$ \%: C 46.80; H 3.93; N 19.85; $\mathrm{S}$ 11.36. Found, \%: C 46.62; H 3.92; N 19.91; S 11.32 .

N-(3-chlorophenyl)-2-hydrazinylpyridine-5-sulfonamide (4f). According to General Procedure B, 2-chloro- $\mathrm{N}$-(3-chlorophenyl)pyridine-5-sulfonamide $3 \mathrm{f}$ (15.2 g, $50 \mathrm{mmol})$ yielded $\mathrm{N}$-(3-chlorophenyl)2-hydrazinylpyridine-5-sulfonamide $4 \mathrm{f}(13.3 \mathrm{~g}, 89 \%)$, as a white solid, m.p. $212-214{ }^{\circ} \mathrm{C}$. $1 \mathrm{H}-\mathrm{NMR}$ spectrum $\delta$, ppm $(J, \mathrm{~Hz}): 4.38$ (br. s, $\left.2 \mathrm{H}, \mathrm{NH}_{2}\right), 6.68(\mathrm{~d}, J=8.0,1 \mathrm{H}, \mathrm{H}-3), 7.00-7.10(\mathrm{~m}, 3 \mathrm{H}, \mathrm{Ar} \mathrm{H}), 7.28(\mathrm{t}$, $J=7.6,1 \mathrm{H}, \mathrm{Ph} \mathrm{H}-5), 7.64(\mathrm{dd}, J=8.0, J=2.2,1 \mathrm{H}, \mathrm{H}-4), 8.26(\mathrm{~d}, J=2.2,1 \mathrm{H}, \mathrm{H}-6), 8.49(\mathrm{~s}, 1 \mathrm{H}, \mathrm{NH})$, 10.20 (br. s, $1 \mathrm{H}, \mathrm{SO}_{2} \mathrm{NH}$ ). Anal. calcd. for $\mathrm{C}_{11} \mathrm{H}_{11} \mathrm{ClN}_{4} \mathrm{O}_{2} \mathrm{~S} \%$ : C 44.22; $\mathrm{H} 3.71 ; \mathrm{N} 18.75 ; \mathrm{S} 10.73$. Found, \%: C 44.07; H 3.72; N 18.78; S 10.76.

$\mathrm{N}$-(4-chlorophenyl)-2-hydrazinylpyridine-5-sulfonamide (4g). According to General Procedure B, 2-chloro- $\mathrm{N}$-(4-chlorophenyl)pyridine-5-sulfonamide $3 \mathrm{~g}$ ( $15.2 \mathrm{~g}$, $50 \mathrm{mmol}$ ) yielded $\mathrm{N}$-(4-chlorophenyl)2-hydrazinylpyridine-5-sulfonamide $4 \mathrm{~g}$ (13.6 g, 91\%), as a white solid, m.p. $224-226^{\circ} \mathrm{C}$. $1 \mathrm{H}-\mathrm{NMR}$ spectrum $\delta, \operatorname{ppm}(J, \mathrm{~Hz}): 4.38$ (br. s, $\left.2 \mathrm{H}, \mathrm{NH}_{2}\right), 6.68(\mathrm{~d}, J=8.0,1 \mathrm{H}, \mathrm{H}-3), 7.09(\mathrm{~d}, J=8.0,2 \mathrm{H}, \mathrm{Ph} \mathrm{H}-3,5)$, $7.28(\mathrm{~d}, J=8.0,2 \mathrm{H}, \mathrm{Ph} \mathrm{H}-2,6), 7.61(\mathrm{dd}, J=8.0, J=2.2,1 \mathrm{H}, \mathrm{H}-4), 8.21(\mathrm{~d}, J=2.2,1 \mathrm{H}, \mathrm{H}-6), 8.50(\mathrm{~s}, 1 \mathrm{H}$, $\mathrm{NH}), 10.12$ (br. s, $1 \mathrm{H}, \mathrm{SO}_{2} \mathrm{NH}$ ). Anal. calcd. for $\mathrm{C}_{11} \mathrm{H}_{11} \mathrm{ClN}_{4} \mathrm{O}_{2} \mathrm{~S} \%$ : C 44.22; $\mathrm{H} 3.71 ; \mathrm{N} 18.75 ; \mathrm{S} 10.73$. Found, \%: C 44.34; H 3.69; N 18.70; S 10.69.

\subsubsection{Synthesis of $N$-(aryl)-[1,2,4]Triazolo[4,3-a]Pyridinesulfonamides 6a-g. General Procedure C}

A corresponding methyl ortho-ester $5 \mathbf{a}-\mathbf{c}(25 \mathrm{mmol})$ was added to a stirred solution of corresponding $\mathrm{N}$-(aryl)-2-hydrazinylpyridinesulfonamide $4 \mathrm{a}-\mathrm{g}(20 \mathrm{mmol})$ in anhydrous DMF $(20 \mathrm{~mL})$. The reaction mixture was refluxed for $16 \mathrm{~h}$. After cooling, the reaction mixture was diluted with water $(100 \mathrm{~mL})$. The precipitate that formed was filtered and recrystallized from a mixture of DMF $(10 \mathrm{~mL})$ and $i$-propanol $(20 \mathrm{~mL}$ ). Yields of $N$-(aryl)-[1,2,4]triazolo[4,3-a]pyridinesulfonamides $\mathbf{6 a}-\mathbf{g}$ were $68-82 \%$. 
N-(3,5-difluorophenyl)-[1,2,4]triazolo[4,3-a]pyridine-8-sulfonamide (6a). According to General Procedure C, N-(3,5-difluorophenyl)-2-hydrazinylpyridine-3-sulfonamide 4a $(6.0 \mathrm{~g}, 20 \mathrm{mmol})$ and methyl ortho-formate $5 \mathbf{a}(2.74 \mathrm{~mL}, 25 \mathrm{mmol})$ yielded $N$-(3,5-difluorophenyl)-[1,2,4]triazolo[4,3-a] pyridine-8-sulfonamide $6 \mathrm{a}(5.09 \mathrm{~g}, 82 \%)$, as a cream solid, m.p. $184-186{ }^{\circ} \mathrm{C}$. ${ }^{1} \mathrm{H}-\mathrm{NMR}$ spectrum $\delta, \operatorname{ppm}(J, \mathrm{~Hz}): 6.70-6.88(\mathrm{~m}, 3 \mathrm{H}, \mathrm{Ar} \mathrm{H}), 7.11(\mathrm{t}, J=7.6,1 \mathrm{H}, \mathrm{H}-6), 8.10(\mathrm{~d}, J=7.6,1 \mathrm{H}, \mathrm{H}-7), 8.79(\mathrm{~d}$, $J=7.6,1 \mathrm{H}, \mathrm{H}-5), 9.40$ (s, $1 \mathrm{H}, \mathrm{H}-3), 11.44$ (br. s, $1 \mathrm{H}, \mathrm{SO}_{2} \mathrm{NH}$ ). Anal. calcd. for $\mathrm{C}_{12} \mathrm{H}_{8} \mathrm{~F}_{2} \mathrm{~N}_{4} \mathrm{O}_{2} \mathrm{~S} \%$ : C 46.45; H 2.60; N 18.06; S 10.33. Found, \%: C 46.29; H 2.61; N 17.99; S 10.38.

N-(3,5-dimethylphenyl)-3-methyl-[1,2,4]triazolo[4,3-a]pyridine-8-sulfonamide (6b). According to General Procedure C, N-(3,5-dimethylphenyl)-2-hydrazinylpyridine-3-sulfonamide $4 \mathrm{~b}$ (5.85 g, $20 \mathrm{mmol})$ and methyl ortho-acetate $5 \mathbf{b}(3.18 \mathrm{~mL}, 25 \mathrm{mmol})$ yielded $N$-(3,5-dimethylphenyl)-3-methyl$[1,2,4]$ triazolo[4,3-a]pyridine-8-sulfonamide $6 \mathbf{b}(4.81 \mathrm{~g}, 76 \%)$, as a cream solid, m.p. $176-178{ }^{\circ} \mathrm{C}$. ${ }^{1} \mathrm{H}-\mathrm{NMR}$ spectrum $\delta$, ppm $(\mathrm{J}, \mathrm{Hz}): 2.06\left(\mathrm{~s}, 6 \mathrm{H}, 2 \mathrm{CH}_{3}\right), 2.68\left(\mathrm{~s}, 3 \mathrm{H}, 3-\mathrm{CH}_{3}\right), 6.57(\mathrm{~s}, 1 \mathrm{H}, \mathrm{Ph} \mathrm{H}-4), 6.70(\mathrm{~s}$, 2H, Ph H-2,6), 7.04 (t, J = 7.6, 1H, H-6), 7.91 (d, J = 7.6, 1H, H-7), 8.53 (d, J = 7.6, 1H, H-5), 10.00 (br. s, $1 \mathrm{H}, \mathrm{SO}_{2} \mathrm{NH}$ ). Anal. calcd. for $\mathrm{C}_{15} \mathrm{H}_{16} \mathrm{~N}_{4} \mathrm{O}_{2} \mathrm{~S}$ \%: C 56.95; H 5.10; N 17.71; $\mathrm{S} 10.13$. Found, \%: C 57.12; H 5.08; N 17.66; S 10.09 .

3-Methyl-N-(3-methylphenyl)-[1,2,4]triazolo[4,3-a]pyridine-6-sulfonamide (6c). According to General Procedure C, N-(3-methylphenyl)-2-hydrazinylpyridine-5-sulfonamide 4c (5.57 g, $20 \mathrm{mmol})$ and methyl ortho-acetate $5 \mathbf{b}(3.18 \mathrm{~mL}, 25 \mathrm{mmol})$ yielded 3-methyl- $N$-(3-methylphenyl)-[1,2,4]triazolo[4,3- $a$ ] pyridine-6-sulfonamide $6 \mathrm{c}(4.23 \mathrm{~g}, 70 \%)$, as a cream solid, m.p. $164-166{ }^{\circ} \mathrm{C} .{ }^{1} \mathrm{H}-\mathrm{NMR}$ spectrum $\delta$, ppm (J, Hz): 2.20 (s, 3H, Ph CH 3$), 2.71\left(\mathrm{~s}, 3 \mathrm{H}, 3-\mathrm{CH}_{3}\right), 6.88(\mathrm{~d}, J=7.6,1 \mathrm{H}, \mathrm{Ar} \mathrm{H}), 6.91-6.98(\mathrm{~m}, 2 \mathrm{H}$, Ar H), 7.11 (t, $J=7.6,1 \mathrm{H}, \mathrm{Ph} \mathrm{H}-5), 7.46$ (d, $J=7.6,1 \mathrm{H}, \mathrm{H}-8), 7.85$ (d, $J=7.6,1 \mathrm{H}, \mathrm{H}-7), 8.76$ (s, 1H, H-5), 10.45 (br. s, $1 \mathrm{H}, \mathrm{SO}_{2} \mathrm{NH}$ ). Anal. calcd. for $\mathrm{C}_{14} \mathrm{H}_{14} \mathrm{~N}_{4} \mathrm{O}_{2} \mathrm{~S} \%$ : C 55.62; $\mathrm{H} 4.67 ; \mathrm{N} 18.53 ; \mathrm{S} 10.60$. Found, \%: C 55.48; H 4.68; N 18.60; S 10.57 .

3-Ethyl-N-(4-methoxyphenyl)-[1,2,4]triazolo[4,3-a]pyridine-6-sulfonamide (6d). According to General Procedure C, 2-hydrazinyl- $N$-(4-methoxyphenyl)pyridine-5-sulfonamide 4d (5.88 g, $20 \mathrm{mmol}$ ) and methyl ortho-propionate $5 \mathrm{c}(3.55 \mathrm{~mL}, 25 \mathrm{mmol})$ yielded 3-ethyl- $N$-(4-methoxyphenyl)-[1,2,4] triazolo[4,3-a]pyridine-6-sulfonamide $6 \mathrm{~d}(4.52 \mathrm{~g}, 68 \%)$, as a cream solid, m.p. $161-163{ }^{\circ} \mathrm{C} .{ }^{1} \mathrm{H}-\mathrm{NMR}$ spectrum $\delta, \operatorname{ppm}(J, \mathrm{~Hz}): 1.28\left(\mathrm{t}, J=7.0,3 \mathrm{H}, \mathrm{CH}_{2} \mathrm{CH}_{3}\right), 3.09\left(\mathrm{q}, J=7.0,2 \mathrm{H}, \mathrm{CH}_{2} \mathrm{CH}_{3}\right), 3.66\left(\mathrm{~s}, 3 \mathrm{H}, \mathrm{OCH}_{3}\right)$, 6.80 (d, J = 7.6, 2H, Ph H-3,5), 7.00 (d, J = 7.6, 2H, Ph H-2,6), 7.44 (d, J = 7.6, 1H, H-8), 7.88 (d, J = 7.6, $1 \mathrm{H}, \mathrm{H}-7), 8.59$ (s, $1 \mathrm{H}, \mathrm{H}-5), 10.22$ (s, $1 \mathrm{H}, \mathrm{SO}_{2} \mathrm{NH}$ ). Anal. calcd. for $\mathrm{C}_{15} \mathrm{H}_{16} \mathrm{~N}_{4} \mathrm{O}_{3} \mathrm{~S} \%$ : C 54.20; $\mathrm{H}$ 4.85; N 16.86; S 9.65. Found, \%: C 54.03; H 4.87; N 16.90; S 9.67.

N-(4-fluorophenyl)-3-methyl-[1,2,4]triazolo[4,3-a]pyridine-6-sulfonamide (6e). According to General Procedure C, N-(4-fluorophenyl)-2-hydrazinylpyridine-5-sulfonamide $4 \mathbf{e}(5.97 \mathrm{~g}, 20 \mathrm{mmol})$ and methyl ortho-acetate $5 \mathbf{b}$ (3.18 mL, $25 \mathrm{mmol}$ ) yielded $N$-(4-fluorophenyl)-3-methyl-[1,2,4]triazolo[4,3- $a$ ] pyridine-6-sulfonamide $6 \mathrm{e}(4.90 \mathrm{~g}, 80 \%)$, as a cream solid, m.p. $176-177^{\circ} \mathrm{C} .{ }^{1} \mathrm{H}-\mathrm{NMR}$ spectrum $\delta$, ppm (J, Hz): 2.69 (s, 3H, 3-CH $\left.\mathrm{CH}_{3}\right), 7.00-7.18(\mathrm{~m}, 4 \mathrm{H}, \mathrm{Ar} \mathrm{H}), 7.40$ (d, J = 7.6, 1H, H-8), $7.87(\mathrm{~d}, J=7.6,1 \mathrm{H}$, $\mathrm{H}-7), 8.68$ (s, $1 \mathrm{H}, \mathrm{H}-5), 10.50$ (br. s, $1 \mathrm{H}, \mathrm{SO}_{2} \mathrm{NH}$ ). Anal. calcd. for $\mathrm{C}_{13} \mathrm{H}_{11} \mathrm{FN}_{4} \mathrm{O}_{2} \mathrm{~S} \%$ : C 50.97; $\mathrm{H} 3.62$; N 18.29; S 10.47. Found, \%: C 51.14; H 3.62; N 18.35; S 10.50.

N-(3-chlorophenyl)-3-methyl-[1,2,4]triazolo[4,3-a]pyridine-6-sulfonamide (6f). According to General Procedure C, N-(3-chlorophenyl)-2-hydrazinylpyridine-5-sulfonamide 4f (5.97 g, $20 \mathrm{mmol}$ ) and methyl ortho-acetate $\mathbf{5 b}(3.18 \mathrm{~mL}, 25 \mathrm{mmol})$ yielded $\mathrm{N}$-(3-chlorophenyl)-3-methyl-[1,2,4]triazolo[4,3-a] pyridine-6-sulfonamide $6 \mathrm{f}(4.97 \mathrm{~g}, 77 \%)$, as a cream solid, m.p. $179-181{ }^{\circ} \mathrm{C} .{ }^{1} \mathrm{H}-\mathrm{NMR}$ spectrum $\delta$, $\operatorname{ppm}(J, \mathrm{~Hz}): 2.70\left(\mathrm{~s}, 3 \mathrm{H}, 3-\mathrm{CH}_{3}\right), 7.01-7.20(\mathrm{~m}, 3 \mathrm{H}, \mathrm{Ar} \mathrm{H}), 7.24(\mathrm{t}, J=7.6,1 \mathrm{H}, \mathrm{Ph} \mathrm{H}-5), 7.44$ (d, J = 7.6, $1 \mathrm{H}, \mathrm{H}-8), 7.88$ (d, $J=7.6,1 \mathrm{H}, \mathrm{H}-7), 8.83$ (s, $1 \mathrm{H}, \mathrm{H}-5), 10.90$ (br. s, $1 \mathrm{H}, \mathrm{SO}_{2} \mathrm{NH}$ ). Anal. calcd. for $\mathrm{C}_{13} \mathrm{H}_{11} \mathrm{ClN}_{4} \mathrm{O}_{2} \mathrm{~S}$ \%: C 48.38; H 3.44; N 17.36; $\mathrm{S}$ 9.93. Found, \%: C 48.22; H 3.42; N 17.41; $\mathrm{S} 9.90$. 
N-(4-chlorophenyl)-3-methyl-[1,2,4]triazolo[4,3-a]pyridine-6-sulfonamide (6g). According to General Procedure C, N-(4-chlorophenyl)-2-hydrazinylpyridine-5-sulfonamide $4 \mathrm{~g}$ (5.97 g, $20 \mathrm{mmol}$ ) and methyl ortho-acetate $5 \mathbf{b}(3.18 \mathrm{~mL}, 25 \mathrm{mmol})$ yielded $N$-(4-chlorophenyl)-3-methyl-[1,2,4]triazolo[4,3-a] pyridine-6-sulfonamide $6 \mathrm{~g}(5.23 \mathrm{~g}, 81 \%)$, as a cream solid, m.p. 206-208 ${ }^{\circ} \mathrm{C} .{ }^{1} \mathrm{H}-\mathrm{NMR}$ spectrum $\delta$, $\operatorname{ppm}(J, \mathrm{~Hz}): 2.70\left(\mathrm{~s}, 3 \mathrm{H}, 3-\mathrm{CH}_{3}\right), 7.15(\mathrm{~d}, J=8.0,2 \mathrm{H}, \mathrm{Ph} \mathrm{H}-3,5), 7.28(\mathrm{~d}, J=8.0,2 \mathrm{H}, \mathrm{Ph} \mathrm{H}-2,6), 7.42(\mathrm{~d}$, $J=7.6,1 \mathrm{H}, \mathrm{H}-8), 7.87$ (d, $J=7.6,1 \mathrm{H}, \mathrm{H}-7), 8.78(\mathrm{~s}, 1 \mathrm{H}, \mathrm{H}-5), 10.75$ (br. s, $\left.1 \mathrm{H}, \mathrm{SO}_{2} \mathrm{NH}\right)$. Anal. calcd. for $\mathrm{C}_{13} \mathrm{H}_{11} \mathrm{ClN}_{4} \mathrm{O}_{2} \mathrm{~S}$ \%: C 48.38; H 3.44; N 17.36; $\mathrm{S}$ 9.93. Found, \%: C 48.47; H 3.46; N 17.30; S 9.97.

3.3.4. Synthesis of $N, N$-Disubstituted $[1,2,4]$ Triazolo[4,3-a]Pyridinesulfonamides 8a-i. General Procedure D

A powder of dry $\mathrm{K}_{2} \mathrm{CO}_{3}(0.42 \mathrm{~g}, 3 \mathrm{mmol})$ was added to a stirred solution of corresponding $\mathrm{N}$-(aryl)-[1,2,4]triazolo[4,3-a]pyridinesulfonamide 6a-g $(1 \mathrm{mmol})$ in anhydrous DMF $(5 \mathrm{~mL})$. Then, appropriate benzyl chloride $7 \mathbf{a}-\mathbf{h}(1.1 \mathrm{mmol})$ was added and the reaction mixture was heated at $90{ }^{\circ} \mathrm{C}$ for $2 \mathrm{~h}$. After cooling, the reaction mixture was diluted with water $(25 \mathrm{~mL})$. The precipitate that formed was filtered off, washed with water $(5 \mathrm{~mL})$ and recrystallized from a mixture of DMF $(5 \mathrm{~mL})$ and $i$-propanol $(20 \mathrm{~mL})$. Yields of $N, N$-disubstituted $[1,2,4]$ triazolo[4,3-a]pyridinesulfonamides $8 \mathbf{a}-\mathbf{i}$ were $60-72 \%$.

$N$-(3-chlorobenzyl)-N-(3,5-difluorophenyl)-[1,2,4]triazolo[4,3-a]pyridine-8-sulfonamide (8a). According to General Procedure D, N-(3,5-difluorophenyl)-[1,2,4]triazolo[4,3-a]pyridine-8-sulfonamide 6a (0.31 g, $1 \mathrm{mmol})$ and 3-chlorobenzyl chloride $7 \mathrm{a}(0.18 \mathrm{~g}, 1.1 \mathrm{mmol})$ yielded $\mathrm{N}$-(3-chlorobenzyl)$\mathrm{N}$-(3,5-difluorophenyl)-[1,2,4]triazolo[4,3-a]pyridine-8-sulfonamide $8 \mathbf{a}(0.27 \mathrm{~g}, 62 \%)$, as a white solid, m.p. $160-162{ }^{\circ} \mathrm{C},{ }^{1} \mathrm{H}-\mathrm{NMR}$ spectrum, $\delta$, ppm $(\mathrm{J}, \mathrm{Hz}): 5.25\left(\mathrm{~s}, 2 \mathrm{H}, \mathrm{CH}_{2}\right), 7.00-7.18(\mathrm{~m}, 4 \mathrm{H}, \mathrm{Ar} \mathrm{H})$, 7.22-7.45 (m, 4H, Ar H), 7.87 (d, J = 7.6, 1H, H-7), 8.88 (d, J = 7.6, 1H, H-5), 9.51 (s, 1H, H-3). ${ }^{13} \mathrm{C}-\mathrm{NMR}$ spectrum, $\delta$, ppm: $53.8\left(\mathrm{CH}_{2}\right), 103.5\left(\mathrm{t}, J_{\mathrm{C}-F}=25.7 \mathrm{~Hz}, \mathrm{Ph} \mathrm{C}-4\right), 111.5\left(\mathrm{dd}, J_{\mathrm{C}-F}=18.1 \mathrm{~Hz}, 9.1 \mathrm{~Hz}, 2 \mathrm{C}\right.$, $\mathrm{Ph} \mathrm{C}-2,6), 112.5,124.4,126.6,127.6,127.7,130.4,130.9,132.9,133.1,137.9,138.8,140.7\left(\mathrm{t}, J_{C-F}=12.8 \mathrm{~Hz}\right.$, Ph C-1), 143.6, 161.9 (dd, $J_{C-F}=246.8 \mathrm{~Hz}, 15.1 \mathrm{~Hz}, 2 \mathrm{C}$, Ph C-3,5). LC/MS m/z (\%): $435.6[\mathrm{M}+\mathrm{H}]^{+}$ (100.0). Anal. calcd. for $\mathrm{C}_{19} \mathrm{H}_{13} \mathrm{ClF}_{2} \mathrm{~N}_{4} \mathrm{O}_{2} \mathrm{~S}$ \%: C 52.48, $\mathrm{H}$ 3.01, N 12.88, $\mathrm{S}$ 7.37. Found, \%: C 52.65, H 2.99, N 12.86, S 7.40.

$N$-(2,5-dimethylbenzyl)-N-(3,5-dimethylphenyl)-3-methyl-[1,2,4]triazolo[4,3-a]pyridine-8-sulfonamide (8b). According to General Procedure D, N-(3,5-dimethylphenyl)-3-methyl-[1,2,4]triazolo[4,3-a]pyridine-8sulfonamide $6 \mathbf{b}(0.31 \mathrm{~g}, 1 \mathrm{mmol})$ and 2,5-dimethylbenzyl chloride $7 \mathbf{b}(0.17 \mathrm{~g}, 1.1 \mathrm{mmol})$ yielded $N$-(2,5-dimethylbenzyl)- $N$-(3,5-dimethylphenyl)-3-methyl-[1,2,4] triazolo[4,3-a]pyridine-8-sulfonamide $8 \mathrm{~b}(0.26 \mathrm{~g}, 60 \%)$, as a white solid, m.p. $195-196{ }^{\circ} \mathrm{C},{ }^{1} \mathrm{H}-\mathrm{NMR}$ spectrum, $\delta, \mathrm{ppm}(J, \mathrm{~Hz}): 2.06(\mathrm{~s}, 6 \mathrm{H}$, $\left.2 \mathrm{CH}_{3}\right), 2.15\left(\mathrm{~s}, 3 \mathrm{H}, \mathrm{CH}_{3}\right), 2.18\left(\mathrm{~s}, 3 \mathrm{H}, \mathrm{CH}_{3}\right), 2.78\left(\mathrm{~s}, 3 \mathrm{H}, 3-\mathrm{CH}_{3}\right), 5.20\left(\mathrm{~s}, 2 \mathrm{H}, \mathrm{CH}_{2}\right), 6.66(\mathrm{~s}, 2 \mathrm{H}, \mathrm{Ph} \mathrm{H}-2,6)$, $6.80(\mathrm{~s}, 1 \mathrm{H}, \mathrm{Ar} \mathrm{H}), 6.88-7.01$ (m, 3H, Ar H), 7.06 (s, 1H, Ar H), 7.55 (d, J = 7.6, 1H, H-7), 8.61 (d, J = 7.6, $1 \mathrm{H}, \mathrm{H}-5) .{ }^{13} \mathrm{C}-\mathrm{NMR}$ spectrum, $\delta$, ppm: $10.0\left(3-\mathrm{CH}_{3}\right), 18.3\left(\mathrm{CH}_{3}\right), 20.6\left(3 \mathrm{C}, \mathrm{CH}_{3}\right), 53.9\left(\mathrm{CH}_{2}\right), 111.6$, 125.4, 126.0 (2 C), 128.0, 129.0, 129.4, 129.6, 130.0, 131.2, 132.9, 134.5, 134.6, 138.0 (2 C), 138.4, 144.6, 145.2. LC/MS m/z (\%): $435.4[\mathrm{M}+\mathrm{H}]^{+}$(100.0). Anal. calcd. for $\mathrm{C}_{24} \mathrm{H}_{26} \mathrm{~N}_{4} \mathrm{O}_{2} \mathrm{~S} \%$ : C 66.33, H 6.03, N 12.89, S 7.38. Found, \%: C 66.15, H 6.05, N 12.95, S 7.41.

N-(3,5-dimethylphenyl)-N-(4-methoxybenzyl)-3-methyl-[1,2,4]triazolo[4,3-a]pyridine-8-sulfonamide (8c). According to General Procedure D, N-(3,5-dimethylphenyl)-3-methyl-[1,2,4]triazolo[4,3-a]pyridine-8sulfonamide $6 \mathbf{b}(0.31 \mathrm{~g}, 1 \mathrm{mmol})$ and 4-methoxybenzyl chloride $7 \mathrm{c}(0.17 \mathrm{~g}, 1.1 \mathrm{mmol})$ yielded $N$-(2,5-dimethylbenzyl)- $N$-(4-methoxyphenyl)-3-methyl-[1,2,4] triazolo[4,3-a]pyridine-8-sulfonamide $8 \mathrm{~b}(0.27 \mathrm{~g}, 62 \%)$, as a white solid, m.p. $168-169{ }^{\circ} \mathrm{C},{ }^{1} \mathrm{H}-\mathrm{NMR}$ spectrum, $\delta, \mathrm{ppm}(\mathrm{J}, \mathrm{Hz}): 2.04(\mathrm{~s}, 6 \mathrm{H}$, $\left.2 \mathrm{CH}_{3}\right), 2.76\left(\mathrm{~s}, 3 \mathrm{H}, 3-\mathrm{CH}_{3}\right), 3.71\left(\mathrm{~s}, 3 \mathrm{H}, \mathrm{OCH}_{3}\right), 5.16\left(\mathrm{~s}, 2 \mathrm{H}, \mathrm{CH}_{2}\right), 6.60(\mathrm{~s}, 2 \mathrm{H}, \mathrm{Ph} \mathrm{H}-2,6), 6.78-6.85(\mathrm{~m}$, $3 \mathrm{H}, \mathrm{Ph} \mathrm{H}-4$ + Bn H-3,5), 7.00 (t, $J=7.6,1 \mathrm{H}, \mathrm{H}-6), 7.19$ (d, $J=8.0,2 \mathrm{H}, \mathrm{Bn} \mathrm{H}-2,6), 7.60$ (d, $J=7.6,1 \mathrm{H}, \mathrm{H}-7)$, $8.62(\mathrm{~d}, J=7.6,1 \mathrm{H}, \mathrm{H}-5) .{ }^{13} \mathrm{C}-\mathrm{NMR}$ spectrum, $\delta$, ppm: $10.0\left(3-\mathrm{CH}_{3}\right), 20.7\left(2 \mathrm{C}, \mathrm{Ph} 3,5-\mathrm{CH}_{3}\right), 55.0\left(\mathrm{CH}_{2}\right)$, $55.6\left(\mathrm{OCH}_{3}\right), 111.6,113.8(2 \mathrm{C}), 125.7,126.1(2 \mathrm{C}), 129.0,129.1,129.3(2 \mathrm{C}), 129.4,131.0,138.1(2 \mathrm{C}), 138.3$, 
144.4, 145.0, 158.6 (Bn C-4). LC/MS m/z (\%): $437.4[\mathrm{M}+\mathrm{H}]^{+}$(100.0). Anal. calcd. for $\mathrm{C}_{23} \mathrm{H}_{24} \mathrm{~N}_{4} \mathrm{O}_{3} \mathrm{~S} \%$ : C 63.28, H 5.54, N 12.83, S 7.35. Found, \%: C 63.44, H 5.55, N 12.89, S 7.32.

Methyl 5-\{[3-methyl-N-(3-methylphenyl)-[1,2,4]triazolo[4,3-a]pyridine-6-sulfonamido]methyl\}furan-2carboxylate (8d). According to General Procedure D, 3-methyl-N-(3-methylphenyl)-[1,2,4]triazolo[4,3-a] pyridine-6-sulfonamide $6 \mathrm{c}(0.30 \mathrm{~g}, 1 \mathrm{mmol})$ and methyl 5-(chloromethyl)furan-2-carboxylate $7 \mathrm{~d}$ (0.19 g, $1.1 \mathrm{mmol})$ yielded methyl 5-\{[3-methyl- $N$-(3-methylphenyl)-[1,2,4]triazolo[4,3-a]pyridine-6sulfonamido]methyl\}furan-2-carboxylate $8 \mathbf{d}(0.28 \mathrm{~g}, 60 \%)$, as a white solid, m.p. $152-154{ }^{\circ} \mathrm{C},{ }^{1} \mathrm{H}-\mathrm{NMR}$ spectrum, $\delta$, ppm $(J, \mathrm{~Hz}): 2.24\left(\mathrm{~s}, 3 \mathrm{H}, \mathrm{Ph} \mathrm{CH}_{3}\right), 2.77\left(\mathrm{~s}, 3 \mathrm{H}, 3-\mathrm{CH}_{3}\right), 3.74\left(\mathrm{~s}, 3 \mathrm{H}, \mathrm{OCH}_{3}\right), 4.98(\mathrm{~s}, 2 \mathrm{H}$, $\left.\mathrm{CH}_{2}\right), 6.42(\mathrm{~d}, J=3.6,1 \mathrm{H}$, furan H-4), $7.00(\mathrm{~d}, J=7.6,1 \mathrm{H}, \mathrm{Ar} \mathrm{H}), 7.06-7.18(\mathrm{~m}, 4 \mathrm{H}, \mathrm{Ar} \mathrm{H}), 7.23(\mathrm{t}$, $J=7.6,1 \mathrm{H}, \mathrm{Ar} \mathrm{H}), 7.81(\mathrm{~d}, J=7.6,1 \mathrm{H}, \mathrm{H}-7), 8.81$ (s, $1 \mathrm{H}, \mathrm{H}-5) .{ }^{13} \mathrm{C}-\mathrm{NMR}$ spectrum, $\delta$, ppm: $9.9\left(3-\mathrm{CH}_{3}\right)$, $20.7\left(\mathrm{CH}_{3}\right), 47.6\left(\mathrm{CH}_{2}\right), 51.8\left(\mathrm{OCH}_{3}\right), 111.8,115.8,119.0,123.8,125.1,125.6,127.3,129.0,129.2,129.4$, 138.2, 138.7, 143.4, 145.8, 148.4, 154.0, 158.0. LC/MS m/z (\%): $441.4[\mathrm{M}+\mathrm{H}]^{+}(100.0)$. Anal. calcd. for $\mathrm{C}_{21} \mathrm{H}_{20} \mathrm{~N}_{4} \mathrm{O}_{5} \mathrm{~S} \%$ : C 57.26, H 4.58, N 12.72, S 7.28. Found, \%: C 57.08, H 4.56, N 12.69, S 7.31.

3-Ethyl-N-(3-fluorobenzyl)-N-(4-methoxyphenyl)-[1,2,4]triazolo[4,3-a]pyridine-6-sulfonamide

$(8 \mathbf{e})$.

According to General Procedure D, 3-ethyl-N-(4-methoxyphenyl)-[1,2,4]triazolo[4,3-a]pyridine-6sulfonamide $6 \mathrm{~d}(0.33 \mathrm{~g}, 1 \mathrm{mmol})$ and 3-fluorobenzyl chloride $7 \mathrm{e}(0.16 \mathrm{~g}, 1.1 \mathrm{mmol})$ yielded 3-ethyl- $N$-(3-fluorobenzyl)- $N$-(4-methoxyphenyl)-[1,2,4]triazolo[4,3-a]pyridine-6-sulfonamide $8 \mathbf{8}$ $(0.28 \mathrm{~g}, 64 \%)$, as a brown solid, m.p. $158-159{ }^{\circ} \mathrm{C},{ }^{1} \mathrm{H}-\mathrm{NMR}$ spectrum, $\delta, \mathrm{ppm}(\mathrm{J}, \mathrm{Hz}): 1.34(\mathrm{t}, J=7.0,3 \mathrm{H}$, $\left.\mathrm{CH}_{2} \mathrm{CH}_{3}\right), 3.18\left(\mathrm{q}, J=7.0,2 \mathrm{H}, \mathrm{CH}_{2} \mathrm{CH}_{3}\right), 3.70\left(\mathrm{~s}, 3 \mathrm{H}, \mathrm{OCH}_{3}\right), 4.83\left(\mathrm{~s}, 2 \mathrm{H}, \mathrm{CH}_{2}\right), 6.83(\mathrm{~d}, J=7.6,2 \mathrm{H}$, Ph H-3,5), 6.98-7.30 (m, 7H, Ar H), 7.85 (d, J = 7.6, 1H, H-7), 8.78 (s, 1H, H-5). ${ }^{13} \mathrm{C}$ NMR spectrum, $\delta$, ppm: $10.8\left(3-\mathrm{Et}_{-} \mathrm{CH}_{3}\right), 17.3\left(3-\mathrm{Et}_{-} \mathrm{CH}_{2}\right), 53.5\left(\mathrm{~N}^{-\mathrm{CH}_{2}}\right), 55.3\left(\mathrm{OCH}_{3}\right), 114.3(2 \mathrm{C}), 114.6,114.7\left(\mathrm{~d}, J_{\mathrm{C}-\mathrm{F}}=\right.$ $27.2 \mathrm{~Hz}), 116.2,124.1\left(\mathrm{~d}, J_{\mathrm{C}-F}=17.4 \mathrm{~Hz}\right), 124.2,125.0,126.9,130.1(2 \mathrm{C}), 130.4\left(\mathrm{~d}, J_{\mathrm{C}-\mathrm{F}}=8.3 \mathrm{~Hz}\right), 130.6$, $139.2\left(\mathrm{~d}, J_{C-F}=7.5 \mathrm{~Hz}\right), 148.5,149.9,158.8(\mathrm{Ph} \mathrm{C}-4), 162.1\left(\mathrm{~d}, J_{C-F}=243.8 \mathrm{~Hz}, \mathrm{Bn} \mathrm{C}-3\right)$. LC/MS m/z (\%): 441.2 [M + H] ${ }^{+}$(100.0). Anal. calcd. for $\mathrm{C}_{22} \mathrm{H}_{21} \mathrm{FN}_{4} \mathrm{O}_{3} \mathrm{~S} \%$ : C 59.99, H 4.81, N 12.72, S 7.28. Found, \%: C $59.82, \mathrm{H} 4.84, \mathrm{~N} 12.65$, S 7.33 .

$\mathrm{N}$-(4-fluorophenyl)-3-methyl-N-(3-methylbenzyl)-[1,2,4]triazolo[4,3-a]pyridine-6-sulfonamide (8f). According to General Procedure D, N-(4-fluorophenyl)-3-methyl-[1,2,4]triazolo[4,3-a]pyridine-6-sulfonamide 6 e $(0.31 \mathrm{~g}, 1 \mathrm{mmol})$ and 3-methylbenzyl chloride $7 \mathrm{f}(0.16 \mathrm{~g}, 1.1 \mathrm{mmol})$ yielded $\mathrm{N}$-(4-fluorophenyl)3-methyl- $N$-(3-methylbenzyl)-[1,2,4] triazolo[4,3-a]pyridine-6-sulfonamide $8 \mathbf{f}(0.25 \mathrm{~g}, 61 \%)$, as a brown solid, m.p. 104-105 ${ }^{\circ} \mathrm{C},{ }^{1} \mathrm{H}-\mathrm{NMR}$ spectrum, $\delta$, ppm $(\mathrm{J}, \mathrm{Hz}): 2.16\left(\mathrm{~s}, 3 \mathrm{H}, \mathrm{Bn} \mathrm{CH}_{3}\right), 2.77\left(\mathrm{~s}, 3 \mathrm{H}, 3-\mathrm{CH}_{3}\right), 4.78(\mathrm{~s}, 2 \mathrm{H}$, $\left.\mathrm{CH}_{2}\right), 6.93-7.28$ (m, 9H, Ar H), $7.82(\mathrm{~d}, J=7.6,1 \mathrm{H}, \mathrm{H}-7), 8.82(\mathrm{~s}, 1 \mathrm{H}, \mathrm{H}-5) .{ }^{13} \mathrm{C}$ NMR spectrum, $\delta$, ppm: 10.3 $\left(3-\mathrm{CH}_{3}\right), 21.3\left(\mathrm{Bn} \mathrm{CH}_{3}\right), 54.5\left(\mathrm{CH}_{2}\right), 116.3\left(\mathrm{~d}, J_{\mathrm{C}-\mathrm{F}}=23.7 \mathrm{~Hz}, 2 \mathrm{C}, \mathrm{Ph} \mathrm{C}-3,5\right), 116.5,124.1,125.6,125.7,127.5$, 127.6, 128.6, 128.7, 129.2, 131.5 (d, $\left.J_{C-F}=9.2 \mathrm{~Hz}, 2 \mathrm{C}, \mathrm{Ph} C-2,6\right), 135.0,136.1,138.0,146.2,161.7\left(\mathrm{~d}, J_{C-F}=243.4\right.$ $\mathrm{Hz}$, Ph C-4). LC/MS m/z (\%): $411.0[\mathrm{M}+\mathrm{H}]^{+}$(100.0). Anal. calcd. for $\mathrm{C}_{21} \mathrm{H}_{19} \mathrm{FN}_{4} \mathrm{O}_{2} \mathrm{~S} \%: \mathrm{C} 61.45, \mathrm{H} 4.67$, N 13.65, S 7.81. Found, \%: C 61.66, H 4.70, N 13.58, S 7.83.

$\mathrm{N}$-(3-chlorobenzyl)-N-(4-fluorophenyl)-3-methyl-[1,2,4]triazolo[4,3-a]pyridine-6-sulfonamide (8g). According to General Procedure D, N-(4-fluorophenyl)-3-methyl-[1,2,4]triazolo[4,3-a]pyridine-6-sulfonamide 6e (0.31 g, $1 \mathrm{mmol})$ and 3-chlorobenzyl chloride $7 \mathrm{a}(0.18 \mathrm{~g}, 1.1 \mathrm{mmol})$ yielded $\mathrm{N}$-(3-chlorobenzyl)$\mathrm{N}$-(4-fluorophenyl)-3-methyl-[1,2,4] triazolo[4,3-a]pyridine-6-sulfonamide $8 \mathbf{g}(0.27 \mathrm{~g}, 63 \%)$, as a pink solid, m.p. $107-109{ }^{\circ} \mathrm{C},{ }^{1} \mathrm{H}-\mathrm{NMR}$ spectrum, $\delta$, ppm $(\mathrm{J}, \mathrm{Hz}): 2.77\left(\mathrm{~s}, 3 \mathrm{H}, 3-\mathrm{CH}_{3}\right), 4.84\left(\mathrm{~s}, 2 \mathrm{H}, \mathrm{CH}_{2}\right), 7.08-7.35(\mathrm{~m}$, 9H, Ar H), $7.83(\mathrm{~d}, J=7.6,1 \mathrm{H}, \mathrm{H}-7), 8.84(\mathrm{~s}, 1 \mathrm{H}, \mathrm{H}-5) .{ }^{13} \mathrm{C}$ NMR spectrum, $\delta$, ppm:10.3 $\left(3-\mathrm{CH}_{3}\right), 53.8\left(\mathrm{CH}_{2}\right)$, $116.4\left(\mathrm{~d}, J_{\mathrm{C}-F}=22.9 \mathrm{~Hz}, 2 \mathrm{C}, \mathrm{Ph} \mathrm{C}-3,5\right), 116.5,124.1,125.3,127.3,127.8,128.0,128.4,130.8,131.4\left(\mathrm{~d}, J_{\mathrm{C}-\mathrm{F}}=\right.$ $9.2 \mathrm{~Hz}, 2 \mathrm{C}, \mathrm{Ph}$ C-2,6), 133.5, 134.8, 138.9, 146.1, 148.9, 161.7 (d, JC-F $=247.2 \mathrm{~Hz}$, Ph C-4). LC/MS m/z (\%): $431.0[\mathrm{M}+\mathrm{H}]^{+}$(100.0). Anal. calcd. for $\mathrm{C}_{20} \mathrm{H}_{16} \mathrm{ClFN}_{4} \mathrm{O}_{2} \mathrm{~S} \%$ : C 55.75, H 3.74, N 13.00, S 7.44. Found, \%: C 55.59, H 3.75, N 12.94, S 7.42. 
N-(3-chlorophenyl)-N-(2-fluorobenzyl)-3-methyl-[1,2,4]triazolo[4,3-a]pyridine-6-sulfonamide (8h). According to General Procedure D, N-(3-chlorophenyl)-3-methyl-[1,2,4]triazolo[4,3-a]pyridine-6-sulfonamide $\mathbf{6 f}$ (0.32 g, $1 \mathrm{mmol})$ and 2-fluorobenzyl chloride $7 \mathrm{~g}(0.16 \mathrm{~g}$, $1.1 \mathrm{mmol})$ yielded $\mathrm{N}$-(3-chlorophenyl)- $\mathrm{N}-(4-$ fluorobenzyl)-3-methyl-[1,2,4]triazolo[4,3-a]pyridine-6-sulfonamide $8 \mathrm{~h}(0.29 \mathrm{~g}, 67 \%)$, as a pink solid, m.p. $153-155^{\circ} \mathrm{C},{ }^{1} \mathrm{H}-\mathrm{NMR}$ spectrum, $\delta$, ppm $(\mathrm{J}, \mathrm{Hz}): 2.77\left(\mathrm{~s}, 3 \mathrm{H}, 3-\mathrm{CH}_{3}\right), 4.94\left(\mathrm{~s}, 2 \mathrm{H}, \mathrm{CH}_{2}\right), 7.03-7.38(\mathrm{~m}$, 9H, Ar H), 7.82 (d, J = 7.6, 1H, H-7), 8.88 (s, 1H, H-5). ${ }^{13} \mathrm{C}$ NMR spectrum, $\delta, ~ p p m: 10.3\left(3-\mathrm{CH}_{3}\right), 48.5\left(\mathrm{CH}_{2}\right)$, $115.7\left(\mathrm{~d}, J_{C-F}=21.4 \mathrm{~Hz}\right), 116.4,122.8\left(\mathrm{~d}, J_{C-F}=13.8 \mathrm{~Hz}\right), 124.1,124.8,125.3,127.9,128.0,128.8,129.2,130.5(\mathrm{~d}$, $\left.J_{C-F}=8.4 \mathrm{~Hz}\right), 130.9,131.5,133.5,140.1,146.3,148.9,160.8\left(\mathrm{~d}, J_{C-F}=248.7 \mathrm{~Hz}\right.$, Bn C-2). LC/MS m/z (\%): 431.4 $[\mathrm{M}+\mathrm{H}]^{+}$(100.0). Anal. calcd. for $\mathrm{C}_{20} \mathrm{H}_{16} \mathrm{ClFN}_{4} \mathrm{O}_{2} \mathrm{~S} \%$ : C 55.75, H 3.74, N 13.00, S 7.44. Found, \%: C 55.62, H 3.73, N 12.96, S 7.48.

$\mathrm{N}$-(4-chlorophenyl)-N-(4-fluorobenzyl)-3-methyl-[1,2,4]triazolo[4,3-a]pyridine-6-sulfonamide (8i). According to General Procedure D, N-(4-chlorophenyl)-3-methyl-[1,2,4]triazolo[4,3-a]pyridine-6-sulfonamide $\mathbf{6 g}$ $(0.32 \mathrm{~g}, 1 \mathrm{mmol})$ and 4-fluorobenzyl chloride $7 \mathrm{~h}(0.16 \mathrm{~g}, 1.1 \mathrm{mmol})$ yielded $\mathrm{N}$-(4-chlorophenyl)$\mathrm{N}$-(4-fluorobenzyl)-3-methyl-[1,2,4]triazolo[4,3-a]pyridine-6-sulfonamide $8 \mathrm{~h}(0.31 \mathrm{~g}, 72 \%)$, as a pink solid, m.p. $198-199^{\circ} \mathrm{C},{ }^{1} \mathrm{H}-\mathrm{NMR}$ spectrum, $\delta$, ppm $(\mathrm{J}, \mathrm{Hz}): 2.77\left(\mathrm{~s}, 3 \mathrm{H}, 3-\mathrm{CH}_{3}\right), 4.81$ (s, $\left.2 \mathrm{H}, \mathrm{CH}_{2}\right), 7.00-7.38$ (m, 9H, Ar H), 7.82 (d, J = 7.6, 1H, H-7), 8.88 (s, 1H, H-5). ${ }^{13} \mathrm{C}$ NMR spectrum, $\delta, ~ p p m: 10.3\left(3-\mathrm{CH}_{3}\right), 53.5\left(\mathrm{CH}_{2}\right)$, $115.7\left(\mathrm{~d}, J_{\mathrm{C}-\mathrm{F}}=21.4 \mathrm{~Hz}, 2 \mathrm{C}\right.$, Bn C-3,5), 116.6, 124.0, 125.4, 127.7, $129.5(2 \mathrm{C}), 130.7$ (d, $J_{\mathrm{C}-F}=8.4 \mathrm{~Hz}, 2 \mathrm{C}$, Bn C-2,6), 131.0 (2C), 132.2, 133.1, 137.5, 146.3, 148.8, 162.0 (d, JC-F $=251.0 \mathrm{~Hz}$, Bn C-4). LC/MS m/z (\%): 431.0 [M + H] $]^{+}$(100.0). Anal. calcd. for $\mathrm{C}_{20} \mathrm{H}_{16} \mathrm{ClFN}_{4} \mathrm{O}_{2} \mathrm{~S} \%$ : C 55.75, H 3.74, N 13.00, S 7.44. Found, \%: C 55.89, H 3.76, N 12.95, S 7.40.

\subsubsection{Synthesis of 2-Chloro-N-Substitutedpyridinesulfonamides 10a-g. General Procedure E}

Secondary amine $9 \mathrm{a}-\mathrm{f}(0.22 \mathrm{~mol})$ was added, for $5 \mathrm{~min}$ at room temperature, to a stirred solution of sulfonyl chloride $1 \mathbf{a}, \mathbf{b}(21.2 \mathrm{~g}, 0.1 \mathrm{~mol})$ in dry dioxane $(100 \mathrm{~mL})$. The reaction mixture was stirred at $60^{\circ} \mathrm{C}$ for $1 \mathrm{~h}$. After cooling, the reaction mixture was diluted with water $(500 \mathrm{~mL})$. The precipitate that formed was filtered and recrystallized from $i$-propanol. Yields of 2-chloro- $N$-substitutedpyridinesulfonamides 10a-g were $67-92 \%$.

2-Chloro-3-(piperidin-1-ylsulfonyl)pyridine (10a). According to General Procedure E, 2-chloropyridine3-sulfonyl chloride 1a $(21.2 \mathrm{~g}, 0.1 \mathrm{~mol})$ and piperidine 9a $(21.7 \mathrm{~mL}, 0.22 \mathrm{~mol})$ yielded 2-chloro-3-(piperidin-1-ylsulfonyl)pyridine $10 \mathrm{a}(22.9 \mathrm{~g}, 88 \%)$, as a white solid, m.p. $116-118{ }^{\circ} \mathrm{C}$. ${ }^{1} \mathrm{H}-\mathrm{NMR}$ spectrum $\delta$, ppm $(\mathrm{J}, \mathrm{Hz}): 1.45-1.55\left(\mathrm{~m}, 6 \mathrm{H}, 3 \mathrm{CH}_{2}\right), 3.16-3.24\left(\mathrm{~m}, 4 \mathrm{H}, 2 \mathrm{NCH}_{2}\right), 7.65(\mathrm{dd}$, $J=8.0, J=7.2,1 \mathrm{H}, \mathrm{H}-5), 8.35(\mathrm{dd}, J=8.0, J=1.5,1 \mathrm{H}, \mathrm{H}-6), 8.65(\mathrm{dd}, J=7.2, J=1.5,1 \mathrm{H}, \mathrm{H}-4)$. Anal. calcd. for $\mathrm{C}_{10} \mathrm{H}_{13} \mathrm{ClN}_{2} \mathrm{O}_{2} \mathrm{~S}$ \%: C 46.06; H 5.03; $\mathrm{N}$ 10.74; $\mathrm{S}$ 12.30. Found, \%: C 45.92; H 5.01; N 10.77; $\mathrm{S} 12.25$.

4-(2-Chloropyridin-3-ylsulfonyl)morpholine (10b). According to General Procedure E, 2-chloropyridine3-sulfonyl chloride 1a $(21.2 \mathrm{~g}, 0.1 \mathrm{~mol})$ and morpholine $9 \mathrm{~b}(19.0 \mathrm{~mL}, 0.22 \mathrm{~mol})$ yielded 4-(2-chloropyridin-3-ylsulfonyl)morpholine $10 \mathrm{~b}(24.2 \mathrm{~g}, 92 \%)$, as a white solid, m.p. $127-128{ }^{\circ} \mathrm{C}$ (128-129 ${ }^{\circ} \mathrm{C}$ [38]). ${ }^{1} \mathrm{H}-\mathrm{NMR}$ spectrum $\delta, \operatorname{ppm}(\mathrm{J}, \mathrm{Hz}): 3.17-3.24\left(\mathrm{~m}, 4 \mathrm{H}, 2 \mathrm{NCH}_{2}\right), 3.55-3.62(\mathrm{~m}, 4 \mathrm{H}$, $\left.2 \mathrm{OCH}_{2}\right), 7.66(\mathrm{dd}, J=8.0, J=7.2,1 \mathrm{H}, \mathrm{H}-5), 8.37(\mathrm{dd}, J=8.0, J=1.5,1 \mathrm{H}, \mathrm{H}-6), 8.67(\mathrm{dd}, J=7.2, J=1.5$, $1 \mathrm{H}, \mathrm{H}-4)$. Anal. calcd. for $\mathrm{C}_{9} \mathrm{H}_{11} \mathrm{ClN}_{2} \mathrm{O}_{3} \mathrm{~S} \%$ : C 41.15; $\mathrm{H}$ 4.22; $\mathrm{N} 10.66$; $\mathrm{S} 12.20$. Found, \%: C 41.02; H 4.21; N 10.70; S 12.24 .

2-Chloro-5-(piperidin-1-ylsulfonyl)pyridine (10c). According to General Procedure E, 2-chloropyridine5-sulfonyl chloride $\mathbf{1 b}(21.2 \mathrm{~g}, 0.1 \mathrm{~mol})$ and piperidine $9 \mathbf{a}(21.7 \mathrm{~mL}, 0.22 \mathrm{~mol})$ yielded 2-chloro-5-(piperidin-1-ylsulfonyl)pyridine $10 \mathrm{c}(24.0 \mathrm{~g}, 92 \%)$, as a white solid, m.p. $114-116{ }^{\circ} \mathrm{C}$. ${ }^{1} \mathrm{H}-\mathrm{NMR}$ spectrum $\delta$, ppm $(J, \mathrm{~Hz}): 1.27-1.58\left(\mathrm{~m}, 6 \mathrm{H}, 3 \mathrm{CH}_{2}\right), 2.88-2.98\left(\mathrm{~m}, 4 \mathrm{H}, 2 \mathrm{NCH}_{2}\right), 7.78(\mathrm{~d}, J=8.0$, $1 \mathrm{H}, \mathrm{H}-3), 8.16(\mathrm{dd}, J=8.0, J=2.2,1 \mathrm{H}, \mathrm{H}-4), 8.73(\mathrm{~d}, J=2.2,1 \mathrm{H}, \mathrm{H}-6)$. Anal. calcd. for $\mathrm{C}_{10} \mathrm{H}_{13} \mathrm{ClN}_{2} \mathrm{O}_{2} \mathrm{~S}$ \%: C 46.06; H 5.03; N 10.74; S 12.30. Found, \%: C 45.95; H 5.04; N 10.71; S 12.32. 
2-Chloro-5-(4-methylpiperidin-1-ylsulfonyl)pyridine (10d). According to General Procedure E, 2-chloropyridine-5-sulfonyl chloride $\mathbf{1 b}(21.2 \mathrm{~g}, 0.1 \mathrm{~mol})$ and 4-methylpiperidine $9 \mathrm{c}(25.4 \mathrm{~mL}, 0.22 \mathrm{~mol})$ yielded 2-chloro-5-(4-methylpiperidin-1-ylsulfonyl)pyridine $10 \mathrm{~d}(23.9 \mathrm{~g}, 87 \%)$, as a white solid, m.p. $105-107{ }^{\circ} \mathrm{C} .{ }^{1} \mathrm{H}-\mathrm{NMR}$ spectrum $\delta$, ppm $(\mathrm{J}, \mathrm{Hz}): 0.86\left(\mathrm{~d}, J=7.0,3 \mathrm{H}, \mathrm{CH}_{3}\right), 0.98-1.40(\mathrm{~m}$, $3 \mathrm{H}), 1.54-1.68(\mathrm{~m}, 2 \mathrm{H}), 2.22-2.40\left(\mathrm{~m}, 2 \mathrm{H}, \mathrm{NCH}_{2}\right), 3.52-3.66\left(\mathrm{~m}, 2 \mathrm{H}, \mathrm{NCH}_{2}\right), 7.77(\mathrm{~d}, J=8.0,1 \mathrm{H}, \mathrm{H}-3)$, $8.17(\mathrm{dd}, J=8.0, J=2.2,1 \mathrm{H}, \mathrm{H}-4), 8.72(\mathrm{~d}, J=2.2,1 \mathrm{H}, \mathrm{H}-6)$. Anal. calcd. for $\mathrm{C}_{11} \mathrm{H}_{15} \mathrm{ClN}_{2} \mathrm{O}_{2} \mathrm{~S} \%: \mathrm{C} 48.08$; H 5.50; N 10.20; S 11.67. Found, \%: C 47.93; H 5.48; N 10.17; S 11.71.

4-(6-Chloropyridin-3-ylsulfonyl)thiomorpholine (10e). According to General Procedure E, 2-chloropyridine5-sulfonyl chloride $\mathbf{1 b}(21.2 \mathrm{~g}, 0.1 \mathrm{~mol})$ and thiomorpholine $9 \mathrm{~d}(22.1 \mathrm{~mL}, 0.22 \mathrm{~mol})$ yielded 4-(6-chloropyridin-3-ylsulfonyl)thiomorpholine $10 \mathrm{e}(24.8 \mathrm{~g}, 89 \%)$, as a white solid, m.p. $117-119{ }^{\circ} \mathrm{C}$. ${ }^{1} \mathrm{H}-\mathrm{NMR}$ spectrum $\delta$, ppm $(J, \mathrm{~Hz}): 2.60-2.68\left(\mathrm{~m}, 4 \mathrm{H}, 2 \mathrm{SCH}_{2}\right), 3.20-3.32\left(\mathrm{~m}, 4 \mathrm{H}, 2 \mathrm{NCH}_{2}\right), 7.79(\mathrm{~d}, J=8.0$, $1 \mathrm{H}, \mathrm{H}-3), 8.18(\mathrm{dd}, J=8.0, J=2.2,1 \mathrm{H}, \mathrm{H}-4), 8.77(\mathrm{~d}, J=2.2,1 \mathrm{H}, \mathrm{H}-6)$. Anal. calcd. for $\mathrm{C}_{9} \mathrm{H}_{11} \mathrm{ClN}_{2} \mathrm{O}_{2} \mathrm{~S}_{2}$ \%: C 38.78; H 3.98; N 10.05; S 23.00. Found, \%: C 38.92; H 3.96; N 10.01; S 22.95.

2-Chloro-3-(pyrrolidine-1-ylsulfonyl)pyridine (10f). According to General Procedure E, 2-chloropyridine3-sulfonyl chloride 1a $(21.2 \mathrm{~g}, 0.1 \mathrm{~mol})$ and pyrrolidine $9 \mathrm{e}(18.1 \mathrm{~mL}, 0.22 \mathrm{~mol})$ yielded 2-chloro-3-(pyrrolidin-1-ylsulfonyl)pyridine $10 \mathrm{f}(21.7 \mathrm{~g}, 88 \%)$, as a white solid, m.p. $101-102{ }^{\circ} \mathrm{C}$. ${ }^{1} \mathrm{H}-\mathrm{NMR}$ spectrum $\delta$, ppm $(\mathrm{J}, \mathrm{Hz}): 1.61-1.70\left(\mathrm{~m}, 4 \mathrm{H}, 2 \mathrm{CH}_{2}\right), 3.16-3.24\left(\mathrm{~m}, 4 \mathrm{H}, 2 \mathrm{NCH}_{2}\right), 7.40(\mathrm{dd}$, $J=8.0, J=7.2,1 \mathrm{H}, \mathrm{H}-5), 8.22(\mathrm{dd}, J=8.0, J=1.5,1 \mathrm{H}, \mathrm{H}-6), 8.52(\mathrm{dd}, J=7.2, J=1.5,1 \mathrm{H}, \mathrm{H}-4)$. Anal. calcd. for $\mathrm{C}_{9} \mathrm{H}_{11} \mathrm{ClN}_{2} \mathrm{O}_{2} \mathrm{~S}$ \%: C 43.82; H 4.49; N 11.35; $\mathrm{S}$ 13.00. Found, \%: C 43.96; H 4.51; N 11.38; 12.95.

1-(2-Chloropyridin-3-ylsulfonyl)-1,2,3,4-tetrahydroquinoline (10g). According to General Procedure E, 2-chloropyridine-3-sulfonyl chloride $1 \mathrm{a}(21.2 \mathrm{~g}, 0.1 \mathrm{~mol})$ and 1,2,3,4-tetrahydroquinoline $9 \mathrm{f}(27.7 \mathrm{~mL}$, $0.22 \mathrm{~mol}$ ) yielded 1-(2-chloropyridin-3-ylsulfonyl)-1,2,3,4-tetrahydroquinoline $10 \mathrm{~g}(20.7 \mathrm{~g}, 67 \%)$, as a white solid, m.p. ${ }^{144-146{ }^{\circ} \mathrm{C} .}{ }^{1} \mathrm{H}-\mathrm{NMR}$ spectrum $\delta$, ppm $(J, \mathrm{~Hz}): 1.82-1.94\left(\mathrm{~m}, 2 \mathrm{H}, \mathrm{THQ} 3-\mathrm{CH}_{2}\right)$, 2.54-2.80 (m, 2H, THQ 4-CH $), 3.37-3.47\left(\mathrm{~m}, 2 \mathrm{H}, \mathrm{THQ} 2-\mathrm{CH}_{2}\right), 6.56(\mathrm{t}, J=7.6,1 \mathrm{H}, \mathrm{Ar} \mathrm{H}), 6.64(\mathrm{~d}, J=7.6$, $1 \mathrm{H}, \mathrm{Ar} \mathrm{H}), 7.02(\mathrm{~d}, J=7.6,1 \mathrm{H}, \mathrm{Ar} \mathrm{H}), 7.13(\mathrm{t}, J=7.6,1 \mathrm{H}, \mathrm{Ar} \mathrm{H}), 7.71(\mathrm{dd}, J=8.0, J=7.2,1 \mathrm{H}, \mathrm{H}-5)$, $8.41(\mathrm{dd}, J=8.0, J=1.5,1 \mathrm{H}, \mathrm{H}-6), 8.68(\mathrm{dd}, J=7.2, J=1.5,1 \mathrm{H}, \mathrm{H}-4)$. Anal. calcd. for $\mathrm{C}_{14} \mathrm{H}_{13} \mathrm{ClN}_{2} \mathrm{O}_{2} \mathrm{~S}$ \%: C 54.46; H 4.24; N 9.07; S 10.38. Found, \%: C 54.64; H 4.22; N 9.11; S 10.41.

\subsubsection{Synthesis of 2-Hydrazinyl-Pyridinesulfonamides 11a-g. General Procedure F}

Corresponding 2-chloro- $N$-substitutedpyridinesulfonamide $10 \mathrm{a}-\mathrm{g}$ (50 $\mathrm{mmol})$ was added to a solution of hydrazine hydrate $(13 \mathrm{~mL}, 200 \mathrm{mmol})$ in $i$-propanol $(50 \mathrm{~mL})$. The reaction mixture was refluxed for $4 \mathrm{~h}$. After cooling, the reaction mixture was diluted with water $(200 \mathrm{~mL})$. The precipitate that formed was filtered and recrystallized from EtOH. The yields of 2-hydrazinyl-pyridinesulfonamides 11a-g were $82-90 \%$.

2-Hydrazinyl-3-(piperidin-1-ylsulfonyl)pyridine (11a). According to General Procedure F, 2-chloro-3(piperidin-1-ylsulfonyl)pyridine 10a (13.0 g, $50 \mathrm{mmol})$ yielded 2-hydrazinyl-3-(piperidin1-ylsulfonyl)pyridine 11a $(11.0 \mathrm{~g}, 86 \%)$, as a white solid, m.p. $154-156{ }^{\circ} \mathrm{C} .{ }^{1} \mathrm{H}-\mathrm{NMR}$ spectrum $\delta$, ppm (J, Hz): 1.26-1.46 (m, 6H, $\left.3 \mathrm{CH}_{2}\right), 3.00-3.15\left(\mathrm{~m}, 4 \mathrm{H}, 2 \mathrm{NCH}_{2}\right), 4.59$ (br. s, $\left.2 \mathrm{H}, \mathrm{NH}_{2}\right), 6.72(\mathrm{t}, J=8.0$, $1 \mathrm{H}, \mathrm{H}-5), 7.85$ (d, $J=8.0,1 \mathrm{H}, \mathrm{H}-6), 8.35$ (d, $J=7.2,1 \mathrm{H}, \mathrm{H}-4), 8.80$ (br. s, $1 \mathrm{H}, \mathrm{NH})$. Anal. calcd. for $\mathrm{C}_{10} \mathrm{H}_{16} \mathrm{~N}_{4} \mathrm{O}_{2} \mathrm{~S}$ \%: C 46.86; H 6.29; N 21.86; S 12.51. Found, \%: C 47.02; H 6.31; N 21.79; 12.46.

4-(2-Hydrazinylpyridin-3-ylsulfonyl)morpholine (11b). According to General Procedure F, 4-(2-chloropyridin3-ylsulfonyl)morpholine $10 \mathrm{~b}$ (13.1 g, $50 \mathrm{mmol}$ ) yielded 4-(2-hydrazinylpyridin-3-ylsulfonyl)morpholine $11 \mathrm{~b}(11.5 \mathrm{~g}, 89 \%)$, as a white solid, m.p. $160-162{ }^{\circ} \mathrm{C}\left(160-161^{\circ} \mathrm{C}[38]\right) .{ }^{1} \mathrm{H}-\mathrm{NMR}$ spectrum $\delta$, ppm $(\mathrm{J}, \mathrm{Hz})$ : 2.93-3.09 (m, 4H, $\left.2 \mathrm{NCH}_{2}\right), 3.61-3.67\left(\mathrm{~m}, 4 \mathrm{H}, 2 \mathrm{OCH}_{2}\right), 4.20$ (br. s, $\left.2 \mathrm{H}, \mathrm{NH}_{2}\right), 7.20(\mathrm{dd}, J=8.0, J=7.2,1 \mathrm{H}$, $\mathrm{H}-5), 8.11(\mathrm{dd}, J=8.0, J=1.5,1 \mathrm{H}, \mathrm{H}-6), 8.51$ (dd, $J=7.2, J=1.5,1 \mathrm{H}, \mathrm{H}-4), 9.00$ (br. s, $1 \mathrm{H}, \mathrm{NH}$ ). Anal. calcd. for $\mathrm{C}_{9} \mathrm{H}_{14} \mathrm{~N}_{4} \mathrm{O}_{3} \mathrm{~S}$ \%: C 41.85; H 5.46; N 21.69; S 12.41. Found, \%: C 41.73; H 5.48; N 21.74; $\mathrm{S} 12.44$. 
2-Hydrazinyl-5-(piperidin-1-ylsulfonyl)pyridine (11c). According to General Procedure F, 2-chloro-5(piperidin-1-ylsulfonyl)pyridine 10c (13.0 g, $50 \mathrm{mmol})$ yielded 2-hydrazinyl-5-(piperidin-1-ylsulfonyl) pyridine 11c $(11.5 \mathrm{~g}, 90 \%)$, as a white solid, m.p. $158-160{ }^{\circ} \mathrm{C} .{ }^{1} \mathrm{H}-\mathrm{NMR}$ spectrum $\delta, \mathrm{ppm}(\mathrm{J}, \mathrm{Hz})$ : $1.26-1.59\left(\mathrm{~m}, 6 \mathrm{H}, 3 \mathrm{CH}_{2}\right), 2.74-2.87\left(\mathrm{~m}, 4 \mathrm{H}, 2 \mathrm{NCH}_{2}\right), 4.36$ (br. s, $\left.2 \mathrm{H}, \mathrm{NH}_{2}\right), 6.78(\mathrm{~d}, J=8.0,1 \mathrm{H}, \mathrm{H}-3)$, $7.63(\mathrm{dd}, J=8.0, J=2.2,1 \mathrm{H}, \mathrm{H}-4), 8.20(\mathrm{~d}, J=2.2,1 \mathrm{H}, \mathrm{H}-6), 8.44$ (br. s, $1 \mathrm{H}, \mathrm{NH})$. Anal. calcd. for $\mathrm{C}_{10} \mathrm{H}_{16} \mathrm{~N}_{4} \mathrm{O}_{2} \mathrm{~S}$ \%: C 46.86; H 6.29; N 21.86; S 12.51. Found, \%: C 47.00; H 6.28; N 21.92; $\mathrm{S} 12.48$.

2-Hydrazinyl-5-(4-methylpiperidin-1-ylsulfonyl)pyridine (11d). According to General Procedure F, 2-chloro- 5-(4-methylpiperidin-1-ylsulfonyl)pyridine 10d (13.7 g, $50 \mathrm{mmol})$ yielded 2-hydrazinyl-5(4-methylpiperidin-1-ylsulfonyl)pyridine $11 \mathrm{~d}(11.6 \mathrm{~g}, 86 \%)$, as a white solid, m.p. $151-153{ }^{\circ} \mathrm{C} .{ }^{1} \mathrm{H}-\mathrm{NMR}$ spectrum $\delta, \operatorname{ppm}(J, \mathrm{~Hz}): 0.86\left(\mathrm{~d}, J=7.0,3 \mathrm{H}, \mathrm{CH}_{3}\right), 0.98-1.36(\mathrm{~m}, 3 \mathrm{H}), 1.54-1.68(\mathrm{~m}, 2 \mathrm{H}), 2.07-2.22$ $\left(\mathrm{m}, 2 \mathrm{H}, \mathrm{NCH}_{2}\right), 3.44-3.56\left(\mathrm{~m}, 2 \mathrm{H}, \mathrm{NCH}_{2}\right), 4.38$ (br. s, $\left.2 \mathrm{H}, \mathrm{NH}_{2}\right), 6.78(\mathrm{~d}, J=8.0,1 \mathrm{H}, \mathrm{H}-3), 7.62(\mathrm{dd}$, $J=8.0, J=2.2,1 \mathrm{H}, \mathrm{H}-4), 8.19$ (d, $J=2.2,1 \mathrm{H}, \mathrm{H}-6), 8.48$ (br. s, $1 \mathrm{H}, \mathrm{NH})$. Anal. calcd. for $\mathrm{C}_{11} \mathrm{H}_{18} \mathrm{~N}_{4} \mathrm{O}_{2} \mathrm{~S}$ \%: C 48.87; H 6.71; N 20.72; S 11.86. Found, \%: C 49.04; H 6.69; N 20.66; S 11.90.

4-(6-Hydrazinylpyridin-3-ylsulfonyl)thiomorpholine (11e). According to General Procedure F, 4-(6chloropyridin-3-ylsulfonyl)thiomorpholine 10e (13.9 g, $50 \mathrm{mmol})$ yielded 4-(6-hydrazinylpyridin3-ylsulfonyl)thiomorpholine 11e $(11.4 \mathrm{~g}, 83 \%)$, as a white solid, m.p. $147-149{ }^{\circ} \mathrm{C} .{ }^{1} \mathrm{H}-\mathrm{NMR}$ spectrum $\delta$, ppm $(J, \mathrm{~Hz}): 2.56-2.68\left(\mathrm{~m}, 4 \mathrm{H}, 2 \mathrm{SCH}_{2}\right), 3.00-3.20\left(\mathrm{~m}, 4 \mathrm{H}, 2 \mathrm{NCH}_{2}\right), 4.44$ (br. s, $\left.2 \mathrm{H}, \mathrm{NH}_{2}\right), 6.78(\mathrm{~d}, J=8.0$, $1 \mathrm{H}, \mathrm{H}-3), 7.63$ (dd, $J=8.0, J=2.2,1 \mathrm{H}, \mathrm{H}-4), 8.22(\mathrm{~d}, J=2.2,1 \mathrm{H}, \mathrm{H}-6), 8.53$ (br. s, $1 \mathrm{H}, \mathrm{NH})$. Anal. calcd. for $\mathrm{C}_{9} \mathrm{H}_{14} \mathrm{~N}_{4} \mathrm{O}_{2} \mathrm{~S}_{2}$ \%: C 39.40; H 5.14; N 20.42; S 23.37. Found, \%: C 39.29; H 5.13; N 20.36; 23.44 .

2-Hydrazinyl-3-(pyrrolidin-1-ylsulfonyl)pyridine (11f). According to General Procedure F, 2-chloro3-(pyrrolidin-1-ylsulfonyl)pyridine $10 \mathrm{f}(12.3 \mathrm{~g}$, $50 \mathrm{mmol})$ yielded 2-hydrazinyl-3-(pyrrolidin1-ylsulfonyl)pyridine 11f $(10.3 \mathrm{~g}, 85 \%)$, as a white solid, m.p. $142-144{ }^{\circ} \mathrm{C} .{ }^{1} \mathrm{H}-\mathrm{NMR}$ spectrum $\delta$, ppm $(J, \mathrm{~Hz}): 1.67-1.73\left(\mathrm{~m}, 4 \mathrm{H}, 2 \mathrm{CH}_{2}\right), 3.15-3.19\left(\mathrm{~m}, 4 \mathrm{H}, 2 \mathrm{NCH}_{2}\right), 4.59$ (br. s, $\left.2 \mathrm{H}, \mathrm{NH}_{2}\right), 7.41$ (dd, $J=8.0, J=7.2,1 \mathrm{H}, \mathrm{H}-5), 8.21(\mathrm{dd}, J=8.0, J=1.5,1 \mathrm{H}, \mathrm{H}-6), 8.51(\mathrm{dd}, J=7.2, J=1.5,1 \mathrm{H}, \mathrm{H}-4), 9.10$ (t, $J=4.0,1 \mathrm{H}, \mathrm{NH})$. Anal. calcd. for $\mathrm{C}_{9} \mathrm{H}_{14} \mathrm{~N}_{4} \mathrm{O}_{2} \mathrm{~S} \%$ : C 44.61; $\mathrm{H}$ 5.82; $\mathrm{N} 23.12 ; \mathrm{S} 13.23$. Found, \%: C 44.49; H 5.81; N 23.07; S 13.18 .

1-(2-Hydrazinylpyridin-3-ylsulfonyl)-1,2,3,4-tetrahydroquinoline (11g). According to General Procedure F, 1-(2-chloropyridin-3-ylsulfonyl)-1,2,3,4-tetrahydroquinoline $10 \mathrm{~g}$ (15.4 $\mathrm{g}, 50 \mathrm{mmol}$ ) yielded 1-(2-hydrazinylpyridin-3-ylsulfonyl)-1,2,3,4-tetrahydroquinoline $11 \mathrm{~g}(12.5 \mathrm{~g}, 82 \%)$, as a white solid, m.p. 167-169 ${ }^{\circ} \mathrm{C} .{ }^{1} \mathrm{H}-\mathrm{NMR}$ spectrum $\delta$, ppm $(\mathrm{J}, \mathrm{Hz}): 1.84-1.92\left(\mathrm{~m}, 2 \mathrm{H}\right.$, THQ 3-CH $\left.\mathrm{CH}_{2}\right), 2.49-2.76(\mathrm{~m}, 2 \mathrm{H}$, THQ 4- $\left.\mathrm{CH}_{2}\right), 3.37-3.47\left(\mathrm{~m}, 2 \mathrm{H}\right.$, THQ 2-CH $\left.\mathrm{CH}_{2}\right), 4.59$ (br. s, 2H, NH$)_{2}, 6.56(\mathrm{t}, J=7.6,1 \mathrm{H}, \mathrm{Ar} \mathrm{H}), 6.64(\mathrm{~d}$, $J=7.6,1 \mathrm{H}, \mathrm{Ar} \mathrm{H}), 7.02(\mathrm{~d}, J=7.6,1 \mathrm{H}, \mathrm{Ar} \mathrm{H}), 7.13(\mathrm{t}, J=7.6,1 \mathrm{H}, \mathrm{Ar} \mathrm{H}), 7.55(\mathrm{dd}, J=8.0, J=7.2,1 \mathrm{H}, \mathrm{H}-5)$, $8.32(\mathrm{dd}, J=8.0, J=1.5,1 \mathrm{H}, \mathrm{H}-6), 8.70(\mathrm{dd}, J=7.2, J=1.5,1 \mathrm{H}, \mathrm{H}-4), 9.30(\mathrm{t}, J=4.0, \mathrm{NH})$. Anal. calcd. for $\mathrm{C}_{14} \mathrm{H}_{16} \mathrm{~N}_{4} \mathrm{O}_{2} \mathrm{~S}$ \%: C 55.25; H 5.30; N 18.41; S 10.53. Found, \%: C 55.38; H 5.28; N 18.37; 10.49 .

3.3.7. Synthesis of Sulfonamido[1,2,4]Triazolo[4,3-a]Pyridin-3-Ones 12a-e. General Procedure G

CDI (4.86 g, $30 \mathrm{mmol})$ was added to a stirred solution of corresponding 2-hydrazinylpyridinesulfonamide 11a- $\mathbf{g}(20 \mathrm{mmol})$ in anhydrous dioxane $(50 \mathrm{~mL})$. The reaction mixture was refluxed for $8 \mathrm{~h}$. After cooling, the reaction mixture was diluted with water $(100 \mathrm{~mL})$. The precipitate that formed was filtered and recrystallized from a mixture of DMF $(10 \mathrm{~mL})$ and $\mathrm{EtOH}(20 \mathrm{~mL})$. Yields of sulfonamido[1,2,4]triazolo[4,3-a]pyridin-3-ones 12a-e were $80-86 \%$.

8-(Piperidin-1-ylsulfonyl)-[1,2,4]triazolo[4,3-a]pyridin-3(2H)-one (12a). According to General Procedure G, 2-hydrazinyl-3-(piperidin-1-ylsulfonyl)pyridine 11a $(5.13 \mathrm{~g}, 20 \mathrm{mmol})$ yielded 8-(piperidin1-ylsulfonyl)-[1,2,4]triazolo[4,3-a]pyridin-3(2H)-one 12a $(4.63 \mathrm{~g}, 82 \%)$, as a white solid, m.p. $284-286{ }^{\circ} \mathrm{C}$. ${ }^{1} \mathrm{H}-\mathrm{NMR}$ spectrum $\delta$, ppm $(J, \mathrm{~Hz}): 1.32-1.54\left(\mathrm{~m}, 6 \mathrm{H}, 3 \mathrm{CH}_{2}\right), 3.08-3.18\left(\mathrm{~m}, 4 \mathrm{H}, 2 \mathrm{NCH}_{2}\right), 6.66(\mathrm{t}, J=7.6$, 
1H, H-6), 7.67 (d, $J=7.6,1 \mathrm{H}, \mathrm{H}-7), 8.02(\mathrm{~d}, J=7.6,1 \mathrm{H}, \mathrm{H}-5), 12.72(\mathrm{~s}, 1 \mathrm{H}, \mathrm{NH})$. Anal. calcd. for $\mathrm{C}_{11} \mathrm{H}_{14} \mathrm{~N}_{4} \mathrm{O}_{3} \mathrm{~S}$ \%: C 46.80; H 5.00; N 19.84; S 11.36. Found, \%: C 46.62; H 4.98; N 19.79; $\mathrm{S} 11.40$.

8-(Morpholinosulfonyl)-[1,2,4]triazolo[4,3-a]pyridin-3(2H)-one (12b). According to General Procedure G, 4-(2-hydrazinylpyridin-3-ylsulfonyl)morpholine $\mathbf{1 1 b}$ (5.16 g, $20 \mathrm{mmol}$ ) yielded 8-(morpholinosulfonyl)[1,2,4]triazolo[4,3-a]pyridin-3(2H)-one $12 b$ (4.83 g, 85\%), as a white solid, m.p. $290-292{ }^{\circ} \mathrm{C}\left(160-161{ }^{\circ} \mathrm{C}\right.$ [L]). ${ }^{1} \mathrm{H}-\mathrm{NMR}$ spectrum $\delta$, ppm $(\mathrm{J}, \mathrm{Hz}): 3.12-3.18\left(\mathrm{~m}, 4 \mathrm{H}, 2 \mathrm{NCH}_{2}\right), 3.52-3.60\left(\mathrm{~m}, 4 \mathrm{H}, 2 \mathrm{OCH}_{2}\right), 6.67(\mathrm{t}$, $J=7.6,1 \mathrm{H}, \mathrm{H}-6), 7.68$ (d, $J=7.6,1 \mathrm{H}, \mathrm{H}-7), 8.08$ (d, $J=7.6,1 \mathrm{H}, \mathrm{H}-5), 12.40$ (br. s, $1 \mathrm{H}, \mathrm{NH})$. Anal. calcd. for $\mathrm{C}_{10} \mathrm{H}_{12} \mathrm{~N}_{4} \mathrm{O}_{4} \mathrm{~S}$ \%: C 42.25; H 4.25; N 19.71; $\mathrm{S} 11.28$. Found, \%: C 42.40; H 4.24; N 21.64; 11.26.

6-(Piperidin-1-ylsulfonyl)-[1,2,4]triazolo[4,3-a]pyridin-3(2H)-one (12c). According to General Procedure G, 2-hydrazinyl- 5-(piperidin-1-ylsulfonyl)pyridine 11c $(5.13 \mathrm{~g}, 20 \mathrm{mmol})$ yielded 6-(piperidin1-ylsulfonyl)-[1,2,4]triazolo[4,3-a]pyridin-3(2H)-one $12 \mathrm{c}(4.87 \mathrm{~g}, 86 \%)$, as a white solid, m.p. $303-305^{\circ} \mathrm{C}$. ${ }^{1} \mathrm{H}-\mathrm{NMR}$ spectrum $\delta, \operatorname{ppm}(\mathrm{J}, \mathrm{Hz}): 1.30-1.56\left(\mathrm{~m}, 6 \mathrm{H}, 3 \mathrm{CH}_{2}\right), 2.95-3.09\left(\mathrm{~m}, 4 \mathrm{H}, 2 \mathrm{NCH}_{2}\right), 7.20-7.38(\mathrm{~m}$, $2 \mathrm{H}, \mathrm{H}-7+\mathrm{H}-8$ ), 8.00 (s, $1 \mathrm{H}, \mathrm{H}-5), 12.55$ (br. s, $1 \mathrm{H}, \mathrm{NH}$ ). Anal. calcd. for $\mathrm{C}_{11} \mathrm{H}_{14} \mathrm{~N}_{4} \mathrm{O}_{3} \mathrm{~S} \%$ : C 46.80; H 5.00; N 19.84; S 11.36. Found, \%: C 46.67; H 4.99; N 19.87; S 11.31.

6-(4-Methylpiperidin-1-ylsulfonyl)-[1,2,4]triazolo[4,3-a]pyridin-3(2H)-one (12d). According to General Procedure G, 2-hydrazinyl-5-(4-methylpiperidin-1-ylsulfonyl)pyridine 11d (5.41 g, $20 \mathrm{mmol}$ ) yielded 6-(4-methylpiperidin-1-ylsulfonyl)-[1,2,4]triazolo[4,3-a]pyridin-3(2H)-one $\mathbf{1 2 d}(4.74 \mathrm{~g}, 80 \%)$, as a white solid, m.p. $279-281^{\circ} \mathrm{C} .{ }^{1} \mathrm{H}-\mathrm{NMR}$ spectrum $\delta$, ppm $(J, \mathrm{~Hz}): 0.86\left(\mathrm{~d}, J=7.0,3 \mathrm{H}, \mathrm{CH}_{3}\right), 0.98-1.36(\mathrm{~m}, 3 \mathrm{H})$, 1.54-1.72 (m, 2H), 2.17-2.42 (m, 2H, NCH $), 3.44-3.60\left(\mathrm{~m}, 2 \mathrm{H}, \mathrm{NCH}_{2}\right), 7.20-7.40(\mathrm{~m}, 2 \mathrm{H}, \mathrm{H}-7+\mathrm{H}-8)$, 8.06 (s, $1 \mathrm{H}, \mathrm{H}-5), 12.60$ (br. s, $1 \mathrm{H}, \mathrm{NH}$ ). Anal. calcd. for $\mathrm{C}_{12} \mathrm{H}_{16} \mathrm{~N}_{4} \mathrm{O}_{3} \mathrm{~S} \%$ : C 48.64; $\mathrm{H}$ 5.44; $\mathrm{N} 18.91$; S 10.82. Found, \%: C 48.81; H 5.46; N 18.86; S 10.79.

6-(Thiomorpholinosulfonyl)-[1,2,4]triazolo[4,3-a]pyridin-3(2H)-one (12e). According to General Procedure G, 4-(6-hydrazinylpyridin-3-ylsulfonyl)thiomorpholine 11e $(5.49 \mathrm{~g}, 20 \mathrm{mmol})$ yielded 6-(thiomorpho linosulfonyl)-[1,2,4]triazolo[4,3-a]pyridin-3(2H)-one 12e $(5.05 \mathrm{~g}, 84 \%)$, as a white solid, m.p. $>320{ }^{\circ} \mathrm{C}$. ${ }^{1} \mathrm{H}-\mathrm{NMR}$ spectrum $\delta$, ppm $(\mathrm{J}, \mathrm{Hz}): 2.52-2.78\left(\mathrm{~m}, 4 \mathrm{H}, 2 \mathrm{SCH}_{2}\right), 3.34-3.50\left(\mathrm{~m}, 4 \mathrm{H}, 2 \mathrm{NCH}_{2}\right), 7.20-7.38(\mathrm{~m}, 2 \mathrm{H}$, $\mathrm{H}-7+\mathrm{H}-8$ ), 8.07 (s, $1 \mathrm{H}, \mathrm{H}-5), 12.75$ (br. s, $1 \mathrm{H}, \mathrm{NH}$ ). Anal. calcd. for $\mathrm{C}_{10} \mathrm{H}_{12} \mathrm{~N}_{4} \mathrm{O}_{3} \mathrm{~S}_{2} \%$ : C 39.99; $\mathrm{H} 4.03$; N 18.65; S 21.35. Found, \%: C 40.12; H 4.01; N 18.59; S 21.27.

3.3.8. Synthesis of 2-Benzyl-Sulfonamido[1,2,4]Triazolo[4,3-a]Pyridin-3-Ones 13a-j. General Procedure H

A powder of dry $\mathrm{K}_{2} \mathrm{CO}_{3}(0.42 \mathrm{~g}, 3 \mathrm{mmol})$ was added to a stirred solution of corresponding sulfonamido[1,2,4]triazolo[4,3-a]pyridin-3-one 12a-e $(1 \mathrm{mmol})$ in anhydrous DMF $(5 \mathrm{~mL})$. Then, appropriate benzyl chloride $\mathbf{7 a}, \mathbf{e}-\mathbf{g}, \mathbf{i}-\mathbf{n}(1.1 \mathrm{mmol})$ was added and the reaction mixture was heated at $100{ }^{\circ} \mathrm{C}$ for $2 \mathrm{~h}$. After cooling, the reaction mixture was diluted with water $(25 \mathrm{~mL})$. The precipitate that formed was filtered off, washed with water $(5 \mathrm{~mL})$ and recrystallized from a mixture of DMF $(5 \mathrm{~mL})$ and $\mathrm{EtOH}(20 \mathrm{~mL})$. The yields of 2-benzyl-sulfonamido[1,2,4]triazolo[4,3-a]pyridin-3-ones 13a-j were $60-65 \%$.

2-(3-Chlorobenzyl)-8-(piperidin-1-ylsulfonyl)-[1,2,4]triazolo[4,3-a]pyridin-3(2H)-one (13a). According to General Procedure H, 8-(piperidin-1-ylsulfonyl)-[1,2,4]triazolo[4,3-a]pyridin-3(2H)-one 12a (0.28 g, $1 \mathrm{mmol})$ and 3-chlorobenzyl chloride $7 \mathrm{a}(0.18 \mathrm{~g}, 1.1 \mathrm{mmol})$ yielded 2-(3-chlorobenzyl)-8(piperidin-1-ylsulfonyl)-[1,2,4]triazolo[4,3-a]pyridin-3(2H)-one 13a $(0.25 \mathrm{~g} 62 \%)$, as a yellow solid, m.p. $176-177^{\circ} \mathrm{C},{ }^{1} \mathrm{H}-\mathrm{NMR}$ spectrum, $\delta$, ppm $(\mathrm{J}, \mathrm{Hz}): 1.29-1.47\left(\mathrm{~m}, 6 \mathrm{H}, 3 \mathrm{CH}_{2}\right), 3.04-3.15(\mathrm{~m}, 4 \mathrm{H}$, $\left.2 \mathrm{NCH}_{2}\right), 5.17\left(\mathrm{~s}, 2 \mathrm{H}, \mathrm{CH}_{2}\right), 6.72(\mathrm{t}, J=7.6,1 \mathrm{H}, \mathrm{H}-6), 7.27-7.40(\mathrm{~m}, 4 \mathrm{H}, \mathrm{Ar} \mathrm{H}), 7.71(\mathrm{~d}, J=7.6,1 \mathrm{H}, \mathrm{H}-7)$, $8.12(\mathrm{~d}, J=7.6,1 \mathrm{H}, \mathrm{H}-5) .{ }^{13} \mathrm{C}-\mathrm{NMR}$ spectrum, $\delta$, ppm: 22.9 (piperidine 4- $\mathrm{CH}_{2}$ ), 25.1 (2C, piperidine 3,5- $\left.\mathrm{CH}_{2}\right), 46.3$ (2C, piperidine 2,6- $\left.\mathrm{CH}_{2}\right), 48.1\left(\mathrm{Bn} \mathrm{CH}_{2}\right), 109.5,124.7,126.6,127.6,127.7,129.0,130.3$, 
133.2, 134.8, 136.8, 138.7, $147.8(\mathrm{C}=\mathrm{O})$. LC/MS m/z (\%): $407.3[\mathrm{M}+\mathrm{H}]^{+}(100.0)$. Anal. calcd. for $\mathrm{C}_{18} \mathrm{H}_{19} \mathrm{ClN}_{4} \mathrm{O}_{3} \mathrm{~S} \%$ : C 53.13, H 4.71, N 13.77, S 7.88. Found, \%: C 52.96, H 4.73, N 13.84, S 7.82.

2-(Benzo[d][1,3]dioxol-5-ylmethyl)-8-(piperidin-1-ylsulfonyl)-[1,2,4]triazolo[4,3-a]pyridin-3(2H)-one (13b). According to General Procedure H, 8-(piperidin-1-ylsulfonyl)-[1,2,4]triazolo[4,3-a]pyridin-3(2H)-one 12a $(0.28 \mathrm{~g}, 1 \mathrm{mmol})$ and 5-(chloromethyl)benzo[d][1,3]dioxole $7 \mathbf{i}(0.19 \mathrm{~g}, 1.1 \mathrm{mmol})$ yielded 2-(benzo[d][1,3]dioxol-5-ylmethyl)-8-(piperidin-1-ylsulfonyl)-[1,2,4]triazolo[4,3-a]pyridin-3(2H)-one $13 \mathrm{~b}(0.25 \mathrm{~g}, 60 \%)$, as a yellow solid, m.p. $160-161^{\circ} \mathrm{C},{ }^{1} \mathrm{H}-\mathrm{NMR}$ spectrum, $\delta, \mathrm{ppm}(J, \mathrm{~Hz}): 1.38-1.52(\mathrm{~m}$, $\left.6 \mathrm{H}, 3 \mathrm{CH}_{2}\right), 3.06-3.18\left(\mathrm{~m}, 4 \mathrm{H}, 2 \mathrm{NCH}_{2}\right), 5.17\left(\mathrm{~s}, 2 \mathrm{H}, \mathrm{CH}_{2}\right), 5.96\left(\mathrm{~s}, 2 \mathrm{H}, \mathrm{OCH}_{2} \mathrm{O}\right), 6.70(\mathrm{t}, J=7.6,1 \mathrm{H}$, H-6), 6.79-6.86 (m, 2H, Ph H-3,4), 6.88 (s, 1H, Ph H-6), 7.68 (d, J = 7.6, 1H, H-7), 8.06 (d, J = 7.6, 1H, $\mathrm{H}-5) .{ }^{13} \mathrm{C}$-NMR spectrum, $\delta$, ppm: 23.4 (piperidine $\left.4-\mathrm{CH}_{2}\right), 25.5\left(2 \mathrm{C}\right.$, piperidine 3,5- $\left.\mathrm{CH}_{2}\right), 46.7(2 \mathrm{C}$, piperidine 2,6- $\left.\mathrm{CH}_{2}\right), 49.2(\mathrm{Bn} \mathrm{CH}), 101.5\left(\mathrm{OCH}_{2} \mathrm{O}\right), 108.5,108.9,109.8,122.0,129.1,130.4,134.9$, 135.0, 136.9, 147.2, 147.8, $148.1(\mathrm{C}=\mathrm{O})$. LC/MS $m / z(\%)$ : $417.2[\mathrm{M}+\mathrm{H}]^{+}$(100.0). Anal. calcd. for $\mathrm{C}_{19} \mathrm{H}_{20} \mathrm{~N}_{4} \mathrm{O}_{5} \mathrm{~S}$ \%: C 54.80, H 4.84, N 13.45, S 7.70. Found, \%: C 54.97, H 4.87, N 13.48, S 7.75.

2-(3,5-Difluorobenzyl)-8-(piperidin-1-ylsulfonyl)-[1,2,4]triazolo[4,3-a]pyridin-3(2H)-one (13c). According to General Procedure H, 8-(piperidin-1-ylsulfonyl)-[1,2,4]triazolo[4,3-a]pyridin-3(2H)-one 12a (0.28 g, $1 \mathrm{mmol})$ and 3,5-difluorobenzyl chloride $7 \mathbf{j}(0.18 \mathrm{~g}, 1.1 \mathrm{mmol})$ yielded 2-(3,5-difluorobenzyl)-8(piperidin-1-ylsulfonyl)-[1,2,4]triazolo[4,3-a]pyridin-3(2H)-one $13 \mathrm{c}(0.26 \mathrm{~g}, 64 \%)$, as a yellow solid, m.p. 221-222 ${ }^{\circ} \mathrm{C},{ }^{1} \mathrm{H}-\mathrm{NMR}$ spectrum, $\delta$, ppm $(\mathrm{J}, \mathrm{Hz}): 1.30-1.48\left(\mathrm{~m}, 6 \mathrm{H}, 3 \mathrm{CH}_{2}\right), 3.09-3.17\left(\mathrm{~m}, 4 \mathrm{H}, 2 \mathrm{NCH}_{2}\right)$, $5.18\left(\mathrm{~s}, 2 \mathrm{H}, \mathrm{CH}_{2}\right), 6.73(\mathrm{t}, J=7.6,1 \mathrm{H}, \mathrm{H}-6), 7.05(\mathrm{~d}, J=9.2,2 \mathrm{H}, \mathrm{Ph} \mathrm{H}-2,6), 7.09(\mathrm{t}, J=9.6,1 \mathrm{H}, \mathrm{Ph} \mathrm{H}-4)$, $7.73(\mathrm{~d}, J=7.6,1 \mathrm{H}, \mathrm{H}-7), 8.11(\mathrm{~d}, J=7.6,1 \mathrm{H}, \mathrm{H}-5) .{ }^{13} \mathrm{C}-\mathrm{NMR}$ spectrum, $\delta$, ppm: 22.9 (piperidine 4- $\mathrm{CH}_{2}$ ), $25.0\left(2 \mathrm{C}\right.$, piperidine 3,5- $\left.\mathrm{CH}_{2}\right), 46.3\left(2 \mathrm{C}\right.$, piperidine 2,6- $\left.\mathrm{CH}_{2}\right), 47.8\left(\mathrm{Bn} \mathrm{CH}_{2}\right), 103.0\left(\mathrm{t}, J_{\mathrm{C}-F}=25.7 \mathrm{~Hz}\right.$, Ph C-4), 109.4, $110.9\left(\mathrm{dd}, J_{C-F}=22.6 \mathrm{~Hz}, 7.9 \mathrm{~Hz}, 2 \mathrm{C}, \mathrm{Ph}\right.$ C-2,6), 124.6, 129.1, 135.0, 137.0, $140.8\left(\mathrm{t}, J_{\mathrm{C}-\mathrm{F}}=\right.$ 9.4 Hz, Ph C-1), 147.9 (C=O), $162.4\left(\mathrm{dd}, J_{\mathrm{C}-\mathrm{F}}=246.0 \mathrm{~Hz}, J_{\mathrm{C}-\mathrm{F}}=13.2 \mathrm{~Hz}, 2 \mathrm{C}, \mathrm{Ph} \mathrm{C}-3,5\right) . \mathrm{LC} / \mathrm{MS} \mathrm{m} / \mathrm{z}(\%)$ : $409.5[\mathrm{M}+\mathrm{H}]^{+}$(100.0). Anal. calcd. for $\mathrm{C}_{18} \mathrm{H}_{18} \mathrm{~F}_{2} \mathrm{~N}_{4} \mathrm{O}_{3} \mathrm{~S} \%$ : C 52.93, H 4.44, N 13.72, S 7.85. Found, \%: C 53.07, H 4.46, N 13.76, S 7.90.

2-(2-Chlorobenzyl)-8-(morpholinosulfonyl)-[1,2,4]triazolo[4,3-a]pyridin-3(2H)-one (13d). According to General Procedure H, 8-(morpholinosulfonyl)-[1,2,4]triazolo[4,3-a]pyridin-3(2H)-one 12b (0.28 g, $1 \mathrm{mmol})$ and 2-chlorobenzyl chloride $7 \mathrm{k}(0.18 \mathrm{~g}$, $1.1 \mathrm{mmol})$ yielded 2-(3-chlorobenzyl)-8-(piperidin1-ylsulfonyl)-[1,2,4]triazolo[4,3-a]pyridin-3(2H)-one $13 \mathrm{a}(0.25 \mathrm{~g}, 62 \%)$, as a yellow solid, m.p. $226-227^{\circ} \mathrm{C},{ }^{1} \mathrm{H}-\mathrm{NMR}$ spectrum, $\delta$, ppm $(\mathrm{J}, \mathrm{Hz}): 3.08-3.12\left(\mathrm{~m}, 4 \mathrm{H}, 2 \mathrm{NCH}_{2}\right), 3.46-3.50(\mathrm{~m}$, $\left.4 \mathrm{H}, 2 \mathrm{OCH}_{2}\right), 5.20\left(\mathrm{~s}, 2 \mathrm{H}, \mathrm{Bn} \mathrm{CH}_{2}\right), 6.74(\mathrm{t}, J=7.6,1 \mathrm{H}, \mathrm{H}-6), 7.28-7.35(\mathrm{~m}, 3 \mathrm{H}, \mathrm{Ar} \mathrm{H}), 7.45(\mathrm{~d}, J=7.6$, $1 \mathrm{H}, \mathrm{Ar} \mathrm{H}), 7.72(\mathrm{~d}, J=7.6,1 \mathrm{H}, \mathrm{H}-7), 8.12$ (d, $J=7.6,1 \mathrm{H}, \mathrm{H}-5) .{ }^{13} \mathrm{C}$ NMR spectrum, $\delta$, ppm: 46.0 (2C, $\left.2 \mathrm{NCH}_{2}\right), 47.2\left(\mathrm{Bn} \mathrm{CH}_{2}\right), 66.1\left(2 \mathrm{C}, 2 \mathrm{OCH}_{2}\right), 109.9,124.8,127.7,129.6,129.8,130.2,131.1,132.9,133.8$, 135.6, 137.1, 148.2 (C=O). LC/MS m/z (\%): $409.1[\mathrm{M}+\mathrm{H}]^{+}(100.0)$. Anal. calcd. for $\mathrm{C}_{17} \mathrm{H}_{17} \mathrm{ClN}_{4} \mathrm{O}_{4} \mathrm{~S} \%$ : C 49.94, H 4.19, N 13.70, S 7.84. Found, \%: C 50.09, H 4.17, N 13.76, S 7.78.

8-(Morpholinosulfonyl)-2-[4-(2-oxopyrrolidin-1-yl)benzyl]-[1,2,4]triazolo[4,3-a]pyridin-3(2H)-one (13e). According to General Procedure H, 8-(morpholinosulfonyl)-[1,2,4]triazolo[4,3-a]pyridin-3(2H)-one $12 \mathbf{b}(0.28 \mathrm{~g}, 1 \mathrm{mmol})$ and 1-(4-(chloromethyl)phenyl)pyrrolidin-2-one 71 (0.23 g, $1.1 \mathrm{mmol})$ yielded 8-(morpholinosulfonyl)-2-[4-(2-oxopyrrolidin-1-yl)benzyl]-[1,2,4]triazolo[4,3-a]pyridin-3(2H)-one 13e $(0.28 \mathrm{~g}, 61 \%)$, as a yellow solid, m.p. $258-260{ }^{\circ} \mathrm{C}$ (dec.), ${ }^{1} \mathrm{H}-\mathrm{NMR}$ spectrum, $\delta, \mathrm{ppm}(J, \mathrm{~Hz}): 2.10$ (qn, $J=$ 7.0, $2 \mathrm{H}$, pyrrolidine $\left.4-\mathrm{CH}_{2}\right), 2.42-2.48\left(\mathrm{~m}, 2 \mathrm{H}\right.$, pyrrolidine $\left.3-\mathrm{CH}_{2}\right), 3.12-3.18\left(\mathrm{~m}, 4 \mathrm{H}, 2 \mathrm{NCH}_{2}\right), 3.46-3.52$ $\left(\mathrm{m}, 4 \mathrm{H}, 2 \mathrm{OCH}_{2}\right), 3.82\left(\mathrm{t}, J=7.0,2 \mathrm{H}\right.$, pyrrolidine $\left.5-\mathrm{CH}_{2}\right), 5.08\left(\mathrm{~s}, 2 \mathrm{H}, \mathrm{Bn} \mathrm{CH}_{2}\right), 6.72(\mathrm{t}, J=7.6,1 \mathrm{H}, \mathrm{H}-6)$, 7.34 (d, $J=7.6,2 \mathrm{H}, \mathrm{Bn} \mathrm{H}-3,5), 7.61$ (d, $J=7.6,2 \mathrm{H}, \mathrm{Bn} \mathrm{H}-2,6), 7.71$ (d, $J=7.6,1 \mathrm{H}, \mathrm{H}-7), 8.09$ (d, $J=7.6$, 1H, H-5). ${ }^{13} \mathrm{C}$ NMR spectrum, $\delta$, ppm: 17.8 (pyrrolidine 4- $\mathrm{CH}_{2}$ ), 32.7 (pyrrolidine 3- $\mathrm{CH}_{2}$ ), 46.1 (2C, $\left.2 \mathrm{NCH}_{2}\right), 48.5$ (pyrrolidine 5- $\left.\mathrm{CH}_{2}\right), 49.0\left(\mathrm{Bn} \mathrm{CH}_{2}\right), 66.1\left(2 \mathrm{C}, 2 \mathrm{OCH}_{2}\right), 109.8,119.9(2 \mathrm{C}), 128.8(2 \mathrm{C})$, 129.4, 129.5, 131.9, 135.4, 136.8, 136.9, $139.6(\mathrm{C}=\mathrm{O}), 174.2$ (pyrrolidone $\mathrm{C}=\mathrm{O})$. LC/MS m/z (\%): 458.1 [M + 
$\mathrm{H}]^{+}$(100.0). Anal. calcd. for $\mathrm{C}_{21} \mathrm{H}_{23} \mathrm{~N}_{5} \mathrm{O}_{5} \mathrm{~S} \%$ : C 55.13, H 5.07, N 15.31, S 7.01. Found, \%: C 52.98, H 5.10, N 15.26, S 6.98 .

2-(4-Chlorobenzyl)-6-(piperidin-1-ylsulfonyl)-[1,2,4]triazolo[4,3-a]pyridin-3(2H)-one (13f). According to General Procedure H, 6-(piperidin-1-ylsulfonyl)-[1,2,4]triazolo[4,3-a]pyridin-3(2H)-one 12c $(0.28 \mathrm{~g}$, $1 \mathrm{mmol})$ and 4-chlorobenzyl chloride $7 \mathrm{~m}(0.18 \mathrm{~g}, 1.1 \mathrm{mmol})$ yielded 2-(4-chlorobenzyl)6-(piperidin-1-ylsulfonyl)-[1,2,4]triazolo[4,3-a]pyridin-3(2H)-one $13 \mathrm{f}(0.26 \mathrm{~g}, 64 \%)$, as a white solid, m.p. $173-174{ }^{\circ} \mathrm{C},{ }^{1} \mathrm{H}-\mathrm{NMR}$ spectrum, $\delta$, ppm $(\mathrm{J}, \mathrm{Hz}): 1.30-1.52\left(\mathrm{~m}, 6 \mathrm{H}, 3 \mathrm{CH}_{2}\right), 2.95-3.09(\mathrm{~m}, 4 \mathrm{H}$, $\left.2 \mathrm{NCH}_{2}\right), 5.15\left(\mathrm{~s}, 2 \mathrm{H}, \mathrm{CH}_{2}\right), 7.28-7.35(\mathrm{~m}, 6 \mathrm{H}, \mathrm{Ar} \mathrm{H}), 8.07$ (s, $\left.1 \mathrm{H}, \mathrm{H}-5\right) .{ }^{13} \mathrm{C}$ NMR spectrum, $\delta$, ppm: 23.3 (piperidine 4- $\left.\mathrm{CH}_{2}\right), 25.3\left(2 \mathrm{C}\right.$, piperidine 3,5- $\left.\mathrm{CH}_{2}\right), 46.7\left(2 \mathrm{C}\right.$, piperidine $\left.2,6-\mathrm{CH}_{2}\right), 48.8\left(\mathrm{Bn} \mathrm{CH}_{2}\right), 116.8$, 122.2, 127.3, 127.4, 128.9 (2C), 130.3 (2C), 132.9, 135.5, 140.7, 148.4 (C=O). LC/MS m/z (\%): 407.1 [M + $\mathrm{H}^{+}$(100.0). Anal. calcd. for $\mathrm{C}_{18} \mathrm{H}_{19} \mathrm{ClN}_{4} \mathrm{O}_{3} \mathrm{~S} \%$ : C 53.13, $\mathrm{H}$ 4.71, N 13.77, $\mathrm{S}$ 7.88. Found, \%: C 52.98, H 4.70, N 13.81, S 7.83 .

2-(3-Methylbenzyl)-6-(4-methylpiperidin-1-ylsulfonyl)-[1,2,4]triazolo[4,3-a]pyridin-3(2H)-one

$(13 g)$. According to General Procedure H, 6-(4-methylpiperidin-1-ylsulfonyl)-[1,2,4]triazolo[4,3-a]pyridin-3 $(2 \mathrm{H})$-one $12 \mathrm{~d}(0.30 \mathrm{~g}, 1 \mathrm{mmol})$ and 3-methylbenzyl chloride $7 \mathrm{f}(0.15 \mathrm{~g}, 1.1 \mathrm{mmol})$ yielded 2-(3-methylbenzyl)-6-(4-methylpiperidin-1-ylsulfonyl)-[1,2,4]triazolo[4,3-a]pyridin-3(2H)-one $\mathbf{1 3 g}$ $(0.24 \mathrm{~g}, 60 \%)$, as a beige solid, m.p. $145-146{ }^{\circ} \mathrm{C},{ }^{1} \mathrm{H}-\mathrm{NMR}$ spectrum, $\delta, \operatorname{ppm}(\mathrm{J}, \mathrm{Hz}): 0.86(\mathrm{~d}, J=7.0,3 \mathrm{H}$, piperidine 4- $\left.\mathrm{CH}_{3}\right), 1.00-1.70(\mathrm{~m}, 5 \mathrm{H}), 2.35\left(\mathrm{~s}, 3 \mathrm{H}, \mathrm{Ph} \mathrm{CH}_{3}\right), 3.52-3.67\left(\mathrm{~m}, 4 \mathrm{H}, 2 \mathrm{NCH}_{2}\right), 5.09(\mathrm{~s}, 2 \mathrm{H}$, $\left.\mathrm{CH}_{2}\right), 7.15-7.40(\mathrm{~m}, 6 \mathrm{H}, \mathrm{Ar} \mathrm{H}), 8.06(\mathrm{~s}, 1 \mathrm{H}, \mathrm{H}-5) .{ }^{13} \mathrm{C}$ NMR spectrum, $\delta, \mathrm{ppm}: 19.2\left(\mathrm{CH}_{3}\right), 21.6$ (piperidine 4- $\mathrm{CH}_{3}$ ), 29.6 (piperidine 4- $\mathrm{CH}$ ), 33.4(2C, piperidine 3,5- $\left.\mathrm{CH}_{2}\right), 46.2\left(2 \mathrm{C}\right.$, piperidine $2,6-\mathrm{CH}_{2}$ ), $47.5\left(\mathrm{Bn} \mathrm{CH}_{2}\right), 116.8,122.1,126.3,127.1,127.4,128.3,129.5,130.6,134.5,136.6,140.6,148.3(\mathrm{C}=\mathrm{O})$. LC/MS m/z (\%): $401.3[\mathrm{M}+\mathrm{H}]^{+}$(100.0). Anal. calcd. for $\mathrm{C}_{20} \mathrm{H}_{24} \mathrm{~N}_{4} \mathrm{O}_{3} \mathrm{~S} \%$ : C 59.98, H 6.04, N 13.99, S 8.01. Found, \%: C 60.11, H 6.05, N 13.94, S 7.98.

2-(2-Fluorobenzyl)-6-(4-methylpiperidin-1-ylsulfonyl)-[1,2,4]triazolo[4,3-a]pyridin-3(2H)-one

(13h). According to General Procedure H, 6-(4-methylpiperidin-1-ylsulfonyl)-[1,2,4]triazolo[4,3-a]pyridin-3 (2H)-one 12d $(0.30 \mathrm{~g}, 1 \mathrm{mmol})$ and 2-fluorobenzyl chloride $7 \mathrm{~g}(0.16 \mathrm{~g}, 1.1 \mathrm{mmol})$ yielded 2-(2-fluorobenzyl)-6-(4-methylpiperidin-1-ylsulfonyl)-[1,2,4]triazolo[4,3-a]pyridin-3(2H)-one $\mathbf{1 3 h}$ $(0.25 \mathrm{~g}, 63 \%)$, as a beige solid, m.p. $150-151{ }^{\circ} \mathrm{C},{ }^{1} \mathrm{H}-\mathrm{NMR}$ spectrum, $\delta, \mathrm{ppm}(\mathrm{J}, \mathrm{Hz}): 0.86(\mathrm{~d}, J=7.0,3 \mathrm{H}$, piperidine 4- $\left.\mathrm{CH}_{3}\right), 1.00-1.70(\mathrm{~m}, 5 \mathrm{H}), 3.52-3.67\left(\mathrm{~m}, 4 \mathrm{H}, 2 \mathrm{NCH}_{2}\right), 5.16\left(\mathrm{~s}, 2 \mathrm{H}, \mathrm{Bn} \mathrm{CH}_{2}\right), 7.12-7.40(\mathrm{~m}$, $6 \mathrm{H}, \mathrm{Ar} \mathrm{H}$ ), 8.06 (s, $1 \mathrm{H}, \mathrm{H}-5) .{ }^{13} \mathrm{C}$ NMR spectrum, $\delta$, ppm: 21.6 (piperidine 4- $\mathrm{CH}_{3}$ ), 29.6 (piperidine 4-CH), $33.4\left(2 \mathrm{C}\right.$, piperidine 3,5- $\left.\mathrm{CH}_{2}\right), 43.4\left(2 \mathrm{C}\right.$, piperidine 2,6- $\left.\mathrm{CH}_{2}\right), 46.2\left(\mathrm{Bn} \mathrm{CH}_{2}\right), 115.8\left(\mathrm{~d}, J_{\mathrm{C}-\mathrm{F}}=\right.$ $19.8 \mathrm{~Hz}), 116.8,122.3,123.2\left(\mathrm{~d}, J_{\mathrm{C}-F}=14.6 \mathrm{~Hz}\right), 124.9,127.3,127.4,130.7,131.2\left(\mathrm{~d}, J_{\mathrm{C}-F}=8.4 \mathrm{~Hz}\right), 140.7$, $148.3(\mathrm{C}=\mathrm{O}), 160.5\left(\mathrm{~d}, J_{\mathrm{C}-F}=251.0 \mathrm{~Hz}, \mathrm{Bn} \mathrm{C}-2\right)$. LC/MS m/z (\%): $405.2[\mathrm{M}+\mathrm{H}]^{+}$(100.0). Anal. calcd. for $\mathrm{C}_{19} \mathrm{H}_{21} \mathrm{FN}_{4} \mathrm{O}_{3} \mathrm{~S} \%$ : C 56.42, H 5.23, N 13.85, S 7.93. Found, \%: C 56.61, H 5.25, N 13.90, S 7.88.

2-(3-Fluorobenzyl)-6-(thiomorpholinosulfonyl)-[1,2,4]triazolo[4,3-a]pyridin-3(2H)-one (13i). According to General Procedure H, 6-(thiomorpholinosulfonyl)-[1,2,4]triazolo[4,3-a]pyridin-3(2H)-one 12e $(0.30 \mathrm{~g}, 1 \mathrm{mmol})$ and 3-fluorobenzyl chloride $7 \mathrm{e}(0.16 \mathrm{~g}, 1.1 \mathrm{mmol})$ yielded 2-(3-fluorobenzyl)6-(thiomorpholinosulfonyl)-[1,2,4]triazolo[4,3-a]pyridin-3(2H)-one $13 \mathbf{i}(0.29 \mathrm{~g}, 65 \%)$, as a white solid, m.p. $154-155{ }^{\circ} \mathrm{C},{ }^{1} \mathrm{H}-\mathrm{NMR}$ spectrum, $\delta$, ppm $(\mathrm{J}, \mathrm{Hz}): 2.60-2.72\left(\mathrm{~m}, 4 \mathrm{H}, 2 \mathrm{SCH}_{2}\right), 3.36-3.50(\mathrm{~m}, 4 \mathrm{H}$, $\left.\left.2 \mathrm{NCH}_{2}\right), 5.15(\mathrm{~s}, 2 \mathrm{H}, \mathrm{Bn} \mathrm{CH})_{2}\right), 7.03-7.43(\mathrm{~m}, 6 \mathrm{H}, \mathrm{Ar} \mathrm{H}), 8.11$ (s, $\left.1 \mathrm{H}, \mathrm{H}-5\right) .{ }^{13} \mathrm{C}$ NMR spectrum, $\delta$, ppm: $27.0\left(2 \mathrm{C}, 2 \mathrm{SCH}_{2}\right), 47.9\left(2 \mathrm{C}, 2 \mathrm{NCH}_{2}\right), 48.8\left(\mathrm{Bn} \mathrm{CH}_{2}\right), 114.9\left(\mathrm{~d}, J_{\mathrm{C}-\mathrm{F}}=21.4 \mathrm{~Hz}, \mathrm{Bn} \mathrm{C}-4\right), 115.1,117.1,122.5$, $124.3,126.9,127.8,131.0\left(\mathrm{~d}, J_{\mathrm{C}-\mathrm{F}}=8.4 \mathrm{~Hz}\right), 139.3,140.8,148.5(\mathrm{C}=\mathrm{O}), 162.6\left(\mathrm{~d}, J_{\mathrm{C}-\mathrm{F}}=244.9 \mathrm{~Hz}, \mathrm{Bn} \mathrm{C}-3\right)$. LC/MS m/z (\%): $409.1[\mathrm{M}+\mathrm{H}]^{+}$(100.0). Anal. calcd. for $\mathrm{C}_{17} \mathrm{H}_{17} \mathrm{FN}_{4} \mathrm{O}_{3} \mathrm{~S}_{2} \%$ : C 49.99, H 4.19, N 13.72, S 15.70. Found, \%: C 50.08, H 4.21, N 13.78, S 15.63. 
12e $(0.30 \mathrm{~g}, 1 \mathrm{mmol})$ and 2-chloro-4-fluorobenzyl chloride $7 \mathrm{n}(0.20 \mathrm{~g}, 1.1 \mathrm{mmol})$ yielded 2-(2-chloro-4-fluorobenzyl)-6-(thiomorpholinosulfonyl)-[1,2,4]triazolo[4,3-a]pyridin-3(2H)-one 13j $(0.26 \mathrm{~g}, 64 \%)$, as a white solid, m.p. $190-191{ }^{\circ} \mathrm{C},{ }^{1} \mathrm{H}-\mathrm{NMR}$ spectrum, $\delta$, ppm $(\mathrm{J}, \mathrm{Hz}): 2.60-2.72(\mathrm{~m}$, $\left.4 \mathrm{H}, 2 \mathrm{SCH}_{2}\right), 3.46-3.50\left(\mathrm{~m}, 4 \mathrm{H}, 2 \mathrm{NCH}_{2}\right), 5.20\left(\mathrm{~s}, 2 \mathrm{H}, \mathrm{Bn} \mathrm{CH}_{2}\right), 7.18-7.53(\mathrm{~m}, 5 \mathrm{H}, \mathrm{Ar} \mathrm{H}), 8.07(\mathrm{~s}, 1 \mathrm{H}$, H-5). ${ }^{13} \mathrm{C}$ NMR spectrum, $\delta$, ppm: $27.0\left(2 \mathrm{C}, 2 \mathrm{SCH}_{2}\right), 46.6\left(2 \mathrm{C}, 2 \mathrm{NCH}_{2}\right), 47.9\left(\mathrm{Bn} \mathrm{CH}_{2}\right), 115.0\left(\mathrm{~d}, J_{\mathrm{C}-\mathrm{F}}=\right.$ $20.6 \mathrm{~Hz}), 117.1,122.6,126.0,127.0,127.8,130.2,131.6,132.5\left(\mathrm{~d}, J_{C-F}=9.2 \mathrm{~Hz}\right), 140.9,148.4(\mathrm{C}=\mathrm{O}), 162.0$ $\left(\mathrm{d}, J_{\mathrm{C}-\mathrm{F}}=248.0 \mathrm{~Hz}, \mathrm{Bn} \mathrm{C}-4\right)$. LC/MS m/z (\%): $443.4[\mathrm{M}+\mathrm{H}]^{+}$(100.0). Anal. calcd. for $\mathrm{C}_{17} \mathrm{H}_{16} \mathrm{ClFN}_{4} \mathrm{O}_{3} \mathrm{~S}_{2}$. Calculated, \%: C 46.10, H 3.64, N 12.65, S 14.48. Found, \%: C 45.94, H 3.62, N 12.59, S 14.53.

\subsubsection{Synthesis of 3-Thioxo-Sulfonamido[1,2,4]Triazolo[4,3-a]Pyridines 14a-c. General Procedure I}

Corresponding 2-hydrazinyl-pyridinesulfonamide 11a,f,g $(20 \mathrm{mmol})$ was dissolved in DMF $(50 \mathrm{~mL})$. Then, triethylamine $(9.76 \mathrm{~mL}, 70 \mathrm{mmol})$ and carbon disulfide $(1.0 \mathrm{~mL}, 40 \mathrm{mmol})$ were added. The reaction mixture was heated at $40{ }^{\circ} \mathrm{C}$ for $2 \mathrm{~h}$, and then the temperature was raised to $90{ }^{\circ} \mathrm{C}$. The obtained solution was heated at $90^{\circ} \mathrm{C}$ for $6 \mathrm{~h}$. After cooling to room temperature, the reaction mixture was acidified by $\mathrm{AcOH}(4.0 \mathrm{~mL}, 70 \mathrm{mmol})$ and diluted with water $(200 \mathrm{~mL})$. The precipitate that formed was filtered, washed with water $(10 \mathrm{~mL})$ and recrystallized from a mixture of DMF $(20 \mathrm{~mL})$ and $\mathrm{EtOH}(20 \mathrm{~mL})$. The yields of 3-thioxo-sulfonamido[1,2,4]triazolo[4,3-a]pyridines 14a-c were $67-74 \%$.

8-(Piperidin-1-ylsulfonyl)-[1,2,4]triazolo[4,3-a]pyridin-3(2H)-thione (14a). According to General Procedure I, 2-hydrazinyl-3-(piperidin-1-ylsulfonyl)pyridine 11a $(5.13 \mathrm{~g}, 20 \mathrm{mmol})$ yielded 8-(piperidin-1ylsulfonyl)-[1,2,4]triazolo[4,3-a]pyridine-3(2H)-thione 14a $(4.30 \mathrm{~g}, 72 \%)$, as a yellow solid, m.p. $303-305^{\circ} \mathrm{C}$. ${ }^{1} \mathrm{H}-\mathrm{NMR}$ spectrum $\delta$, ppm $(\mathrm{J}, \mathrm{Hz}): 1.46-1.54\left(\mathrm{~m}, 6 \mathrm{H}, 3 \mathrm{CH}_{2}\right), 3.16-3.24(\mathrm{~m}, 4 \mathrm{H}$, $\left.2 \mathrm{NCH}_{2}\right), 7.05(\mathrm{dd}, J=8.0, J=7.2,1 \mathrm{H}, \mathrm{H}-6), 7.90(\mathrm{dd}, J=7.0, J=1.5,1 \mathrm{H}, \mathrm{H}-7), 8.45(\mathrm{dd}, J=8.0, J=1.5$, $1 \mathrm{H}, \mathrm{H}-5), 14.85$ (s, $1 \mathrm{H}, \mathrm{NH})$. Anal. calcd. for $\mathrm{C}_{11} \mathrm{H}_{14} \mathrm{~N}_{4} \mathrm{O}_{2} \mathrm{~S}_{2} \%$ : C 44.28; $\mathrm{H} 4.73 ; \mathrm{N} 18.78 ; \mathrm{S}$ 21.49. Found, \%: C 44.43; H 4.72; N 18.72; S 21.41.

8-(Pyrrolidin-1-ylsulfonyl)-[1,2,4]triazolo[4,3-a]pyridin-3(2H)-thione (14b). According to General Procedure I, 2-hydrazinyl-3-(pyrrolidin-1-ylsulfonyl)pyridine 11f (4.85 g, $20 \mathrm{mmol})$ yielded 8-(pyrrolidin-1-ylsulfonyl)-[1,2,4]triazolo[4,3-a]pyridine-3(2H)-thione $\mathbf{1 4 b}(4.21 \mathrm{~g}, 74 \%)$, as a yellow solid, m.p. $303-305{ }^{\circ} \mathrm{C} .{ }^{1} \mathrm{H}-\mathrm{NMR}$ spectrum $\delta$, ppm $(\mathrm{J}, \mathrm{Hz}): 1.62-1.78\left(\mathrm{~m}, 4 \mathrm{H}, 2 \mathrm{CH}_{2}\right), 3.32-3.40(\mathrm{~m}, 4 \mathrm{H}$, $\left.2 \mathrm{NCH}_{2}\right), 7.06(\mathrm{t}, J=7.2,1 \mathrm{H}, \mathrm{H}-6), 7.93(\mathrm{~d}, J=7.2,1 \mathrm{H}, \mathrm{H}-7), 8.44(\mathrm{~d}, J=7.6,1 \mathrm{H}, \mathrm{H}-5), 14.70(\mathrm{~s}, 1 \mathrm{H}, \mathrm{NH})$. Anal. calcd. for $\mathrm{C}_{10} \mathrm{H}_{12} \mathrm{~N}_{4} \mathrm{O}_{2} \mathrm{~S}_{2}$ \%: C 42.24; $\mathrm{H} 4.25 ; \mathrm{N}$ 19.70; $\mathrm{S} 22.55$. Found, \%: C 42.36; H 4.27; N 19.63; S 22.49 .

8-(3,4-Dihydroquinolin-1(2H)-ylsulfonyl)-[1,2,4]triazolo[4,3-a]pyridin-3(2H)-thione (14c). According to General Procedure I, 1-(2-hydrazinylpyridin-3-ylsulfonyl)-1,2,3,4-tetrahydroquinoline 11g (6.09 g, $20 \mathrm{mmol}$ ) yielded 8-(3,4-dihydroquinolin-1(2H)-ylsulfonyl)-[1,2,4]triazolo[4,3-a]pyridine-3(2H)-thione 14c $(4.64 \mathrm{~g}, 67 \%)$, as a yellow solid, m.p. $>320{ }^{\circ} \mathrm{C} .{ }^{1} \mathrm{H}-\mathrm{NMR}$ spectrum $\delta, \operatorname{ppm}(\mathrm{J}, \mathrm{Hz}): 1.82-1.94(\mathrm{~m}, 2 \mathrm{H}$, THQ 3- $\left.\mathrm{CH}_{2}\right), 2.49-2.79\left(\mathrm{~m}, 2 \mathrm{H}\right.$, THQ 4-CH $\mathrm{CH}_{2}, 3.37-3.47\left(\mathrm{~m}, 2 \mathrm{H}, \mathrm{THQ} 2-\mathrm{CH}_{2}\right), 6.56(\mathrm{t}, J=7.6,1 \mathrm{H}, \mathrm{Ar} \mathrm{H})$, $6.64(\mathrm{~d}, J=7.6,1 \mathrm{H}, \mathrm{Ar} \mathrm{H}), 7.02(\mathrm{~d}, J=7.6,1 \mathrm{H}, \mathrm{Ar} \mathrm{H}), 7.08-7.16(\mathrm{~m}, 2 \mathrm{H}, \mathrm{H}-6+\mathrm{Ar} \mathrm{H}), 7.93(\mathrm{~d}, J=7.2,1 \mathrm{H}$, $\mathrm{H}-7), 8.51(\mathrm{~d}, J=7.6,1 \mathrm{H}, \mathrm{H}-5), 14.95(\mathrm{~s}, 1 \mathrm{H}, \mathrm{NH})$. Anal. calcd. for $\mathrm{C}_{15} \mathrm{H}_{14} \mathrm{~N}_{4} \mathrm{O}_{2} \mathrm{~S}_{2} \%$ : C 52.01; $\mathrm{H} 4.07$; N 16.17; S 18.51. Found, \%: C 51.84; H 4.09; N 16.23; S 18.45.

\subsubsection{Synthesis of 3-Thio-Sulfonamido[1,2,4]Triazolo[4,3-a]Pyridines 15a-f. General Procedure J}

The corresponding benzyl chloride $\mathbf{7 a}, \mathbf{c}, \mathbf{h}, \mathbf{k}, \mathbf{o}, \mathbf{p}(1.1 \mathrm{mmol})$ was added to the stirred solution of 3-thioxo-sulfonamido[1,2,4]triazolopyridine 14a-c $(1 \mathrm{mmol})$ and triethylamine $(0.17 \mathrm{~mL}, 1.2 \mathrm{mmol})$ in anhydrous DMF $(5 \mathrm{~mL})$. The reaction mixture was heated at $80{ }^{\circ} \mathrm{C}$ for $2 \mathrm{~h}$. After cooling, the reaction mixture was diluted with water $(25 \mathrm{~mL})$. The precipitate that formed was filtered off, washed with water $(5 \mathrm{~mL})$ and recrystallized from a mixture of DMF $(5 \mathrm{~mL})$ and EtOH $(20 \mathrm{~mL})$. The yields of 3-thio-sulfonamido[1,2,4] triazolo[4,3-a]pyridines 15a-f were $81-94 \%$. 
3-(4-Methoxybenzylthio)-8-(piperidin-1-ylsulfonyl)-[1,2,4]triazolo[4,3-a]pyridine (15a). According to General Procedure H, 8-(piperidin-1-ylsulfonyl)-[1,2,4]triazolo[4,3-a]pyridine-3(2H)-thione 14a $(0.30 \mathrm{~g}$, $1 \mathrm{mmol})$ and 4-methoxybenzyl chloride $7 \mathrm{c}(0.17 \mathrm{~g}, 1.1 \mathrm{mmol})$ yielded 3-(4-methoxybenzylthio)8-(piperidin-1-ylsulfonyl)-[1,2,4]triazolo[4,3-a]pyridine $15 \mathrm{a}(0.34 \mathrm{~g}, 81 \%)$, as a cream solid, m.p. $169-170{ }^{\circ} \mathrm{C},{ }^{1} \mathrm{H}-\mathrm{NMR}$ spectrum, $\delta$, ppm $(J, \mathrm{~Hz}): 1.30-1.52\left(\mathrm{~m}, 6 \mathrm{H}, 3 \mathrm{CH}_{2}\right), 3.16-3.25(\mathrm{~m}, 4 \mathrm{H}$, $\left.2 \mathrm{NCH}_{2}\right), 3.66\left(\mathrm{~s}, 3 \mathrm{H}, \mathrm{OCH}_{3}\right), 4.28\left(\mathrm{~s}, 2 \mathrm{H}, \mathrm{Bn} \mathrm{CH}_{2}\right), 6.72(\mathrm{~d}, J=8.0,2 \mathrm{H}, \mathrm{Bn} \mathrm{H}-3,5), 7.02-7.12(\mathrm{~m}, 3 \mathrm{H}$, H-6 + Bn H-2,6), 7.85 (d, $J=7.2,1 \mathrm{H}, \mathrm{H}-7), 8.38$ (d, $J=7.2,1 \mathrm{H}, \mathrm{H}-5) .{ }^{13} \mathrm{C}-\mathrm{NMR}$ spectrum, $\delta$, ppm: 23.0 (piperidine 4- $\left.\mathrm{CH}_{2}\right), 25.1$ (2C, piperidine 3,5- $\left.\mathrm{CH}_{2}\right), 38.2\left(\mathrm{Bn} \mathrm{CH}_{2}\right), 46.6\left(2 \mathrm{C}\right.$, piperidine 2,6- $\left.\mathrm{CH}_{2}\right), 55.1$ $\left(\mathrm{OCH}_{3}\right), 113.0,113.8(2 \mathrm{C}), 125.4,128.3,128.6,130.1$ (2C), 131.5, 141.5, 145.9, 158.7 (Bn C-4). LC/MS m/z (\%): $419.4[\mathrm{M}+\mathrm{H}]^{+}$(100.0). Anal. calcd. for $\mathrm{C}_{19} \mathrm{H}_{22} \mathrm{~N}_{4} \mathrm{O}_{3} \mathrm{~S}_{2} \%$ : C 54.53, H 5.30, N 13.39, S 15.32. Found, \%: C 54.36, H 5.29, N 13.42, S 15.38 .

3-(3-Bromobenzylthio)-8-(piperidin-1-ylsulfonyl)-[1,2,4]triazolo[4,3-a]pyridine (15b). According to General Procedure H, 8-(piperidin-1-ylsulfonyl)-[1,2,4]triazolo[4,3-a]pyridine-3(2H)-thione 14a (0.30 g, $1 \mathrm{mmol})$ and 3-bromobenzyl chloride $7 \mathrm{o}(0.23 \mathrm{~g}, 1.1 \mathrm{mmol})$ yielded 3-(3-bromobenzylthio)8-(piperidin-1-ylsulfonyl)-[1,2,4]triazolo[4,3-a]pyridine $\mathbf{1 5 b}(0.44 \mathrm{~g}, 94 \%)$, as a cream solid, m.p. $160-162{ }^{\circ} \mathrm{C},{ }^{1} \mathrm{H}-\mathrm{NMR}$ spectrum, $\delta$, ppm $(\mathrm{J}, \mathrm{Hz}): 1.32-1.52\left(\mathrm{~m}, 6 \mathrm{H}, 3 \mathrm{CH}_{2}\right), 3.16-3.25(\mathrm{~m}, 4 \mathrm{H}$, $\left.2 \mathrm{NCH}_{2}\right), 4.30(\mathrm{~s}, 2 \mathrm{H}, \mathrm{Bn} \mathrm{CH})_{2}, 7.05-7.23(\mathrm{~m}, 3 \mathrm{H}, \mathrm{H}-6+\mathrm{Ar} \mathrm{H}), 7.05-7.23(\mathrm{~m}, 2 \mathrm{H}, \mathrm{Ar} \mathrm{H}), 7.86(\mathrm{~d}, J=7.2$, $1 \mathrm{H}, \mathrm{H}-7), 8.40$ (d, $J=7.2,1 \mathrm{H}, \mathrm{H}-5) .{ }^{13} \mathrm{C}-\mathrm{NMR}$ spectrum, $\delta$, ppm: 23.0 (piperidine $4-\mathrm{CH}_{2}$ ), $25.1(2 \mathrm{C}$, piperidine 3,5- $\left.\mathrm{CH}_{2}\right), 37.6\left(\mathrm{Bn} \mathrm{CH}_{2}\right), 46.6\left(2 \mathrm{C}\right.$, piperidine 2,6- $\left.\mathrm{CH}_{2}\right), 113.1,121.4,125.4,128.0,128.2$, 130.3, 130.6, 131.5, 131.6, 139.9, 141.1, 146.1. LC/MS m/z (\%): $469.1[\mathrm{M}+\mathrm{H}]^{+}(100.0)$. Anal. calcd. for $\mathrm{C}_{18} \mathrm{H}_{19} \mathrm{BrN}_{4} \mathrm{O}_{2} \mathrm{~S}_{2}$ \%: C 46.26, H 4.10, N 11.99, S 13.72. Found, \%: C 46.11, H 4.09, N 12.04, S 13.68.

3-(4-Methylbenzylthio)-8-(piperidin-1-ylsulfonyl)-[1,2,4]triazolo[4,3-a]pyridine (15c). According to General Procedure H, 8-(piperidin-1-ylsulfonyl)-[1,2,4]triazolo[4,3-a]pyridine-3(2H)-thione 14a (0.30 g, $1 \mathrm{mmol})$ and 4-methylbenzyl chloride $7 \mathrm{p}(0.15 \mathrm{~g}, 1.1 \mathrm{mmol})$ yielded 3-(4-methylbenzylthio)8-(piperidin-1-ylsulfonyl)-[1,2,4]triazolo[4,3-a]pyridine $15 \mathrm{c}(0.37 \mathrm{~g}, 92 \%)$, as a cream solid, m.p. $155-156{ }^{\circ} \mathrm{C},{ }^{1} \mathrm{H}-\mathrm{NMR}$ spectrum, $\delta$, ppm $(\mathrm{J}, \mathrm{Hz}): 1.30-1.50\left(\mathrm{~m}, 6 \mathrm{H}, 3 \mathrm{CH}_{2}\right), 2.18\left(\mathrm{~s}, 3 \mathrm{H}, \mathrm{CH}_{3}\right)$, 3.16-3.25 (m, 4H, $\left.2 \mathrm{NCH}_{2}\right), 4.28\left(\mathrm{~s}, 2 \mathrm{H}, \mathrm{Bn} \mathrm{CH}_{2}\right), 6.93-7.09(\mathrm{~m}, 5 \mathrm{H}, \mathrm{H}-6+\mathrm{Ar} \mathrm{H}), 7.86(\mathrm{~d}, J=7.2,1 \mathrm{H}$, $\mathrm{H}-7), 8.38(\mathrm{~d}, J=7.2,1 \mathrm{H}, \mathrm{H}-5) .{ }^{13} \mathrm{C}-\mathrm{NMR}$ spectrum, $\delta$, ppm: $20.6\left(\mathrm{CH}_{3}\right), 23.0$ (piperidine 4- $\mathrm{CH}_{2}$ ), 25.1 (piperidine $\mathrm{CH}_{2}$ ), 25.5 (piperidine $\left.\mathrm{CH}_{2}\right), 38.3\left(\mathrm{Bn} \mathrm{CH}_{2}\right), 46.6\left(2 \mathrm{C}\right.$, piperidine 2,6- $\left.\mathrm{CH}_{2}\right), 112.9,125.4$, 128.3, 128.8 (2 C), 129.0 (2 C), 131.5, 133.7, 136.8, 141.4, 145.9. LC/MS m/z (\%): $403.4[\mathrm{M}+\mathrm{H}]^{+}(100.0)$. Anal. calcd. for $\mathrm{C}_{19} \mathrm{H}_{22} \mathrm{~N}_{4} \mathrm{O}_{2} \mathrm{~S}_{2}$ \%: C 56.69, H 5.51, N 13.92, S 15.93. Found, \%: C 56.86, H 5.49, N 13.87, S 15.88 .

3-(3-Chlorobenzylthio)-8-(pyrrolidin-1-ylsulfonyl)-[1,2,4]triazolo[4,3-a]pyridine (15d). According to General Procedure H, 8-(pyrrolidin-1-ylsulfonyl)-[1,2,4]triazolo[4,3-a]pyridine-3(2H)-thione $\mathbf{1 4 b}(0.28 \mathrm{~g}$, $1 \mathrm{mmol})$ and 3-chlorobenzyl chloride $7 \mathrm{a}(0.18 \mathrm{~g}, 1.1 \mathrm{mmol})$ yielded 3-(3-chlorobenzylthio)8-(pyrrolidin-1-ylsulfonyl)-[1,2,4]triazolo[4,3-a]pyridine $15 \mathrm{~d}(0.38 \mathrm{~g}, 93 \%)$, as a cream solid, m.p. $143-145{ }^{\circ} \mathrm{C},{ }^{1} \mathrm{H}-\mathrm{NMR}$ spectrum, $\delta$, ppm $(\mathrm{J}, \mathrm{Hz})$ : $1.59-1.74\left(\mathrm{~m}, 4 \mathrm{H}, 2 \mathrm{CH}_{2}\right), 3.40-3.52(\mathrm{~m}, 4 \mathrm{H}$, $\left.2 \mathrm{NCH}_{2}\right), 4.31\left(\mathrm{~s}, 2 \mathrm{H}, \mathrm{Bn} \mathrm{CH} \mathrm{CH}_{2}\right), 7.02-7.22(\mathrm{~m}, 5 \mathrm{H}, \mathrm{H}-6+\mathrm{Ar} \mathrm{H}), 7.91$ (d, J = 7.2, 1H, H-7), 8.40 (d, $J=7.2,1 \mathrm{H}, \mathrm{H}-5) .{ }^{13} \mathrm{C}-\mathrm{NMR}$ spectrum, 8 , ppm: $25.3\left(2 \mathrm{C}\right.$, pyrrolidine $\left.3,4-\mathrm{CH}_{2}\right), 37.7\left(\mathrm{Bn} \mathrm{CH}_{2}\right), 47.9(2 \mathrm{C}$, pyrrolidine 2,5- $\left.\mathrm{CH}_{2}\right), 113.1,125.3,127.4,127.6,128.2,128.7,130.2,132.4,132.9,139.7,141.1,146.2$. LC/MS m/z (\%): $409.4[\mathrm{M}+\mathrm{H}]^{+}$(100.0). Anal. calcd. for $\mathrm{C}_{17} \mathrm{H}_{17} \mathrm{ClN}_{4} \mathrm{O}_{2} \mathrm{~S}_{2} \%$ : C 49.93, H 4.19, $\mathrm{N}$ 13.70, S 15.68. Found, \%: C 50.11, H 4.18, N 13.65, S 15.72.

3-(2-Chlorobenzylthio)-8-(pyrrolidin-1-ylsulfonyl)-[1,2,4]triazolo[4,3-a]pyridine (15e). According to General Procedure H, 8-(pyrrolidin-1-ylsulfonyl)-[1,2,4]triazolo[4,3-a]pyridine-3(2H)-thione 14b (0.28 g, $1 \mathrm{mmol})$ and 2-chlorobenzyl chloride $7 \mathrm{k}(0.18 \mathrm{~g}, 1.1 \mathrm{mmol})$ yielded 3-(2-chlorobenzylthio)8-(pyrrolidin-1-ylsulfonyl)-[1,2,4]triazolo[4,3-a]pyridine $15 \mathrm{e}(0.36 \mathrm{~g}, 88 \%)$, as a cream solid, m.p. $164-166^{\circ} \mathrm{C},{ }^{1} \mathrm{H}-\mathrm{NMR}$ spectrum, $\delta$, ppm $(\mathrm{J}, \mathrm{Hz}): 1.59-1.74\left(\mathrm{~m}, 4 \mathrm{H}, 2 \mathrm{CH}_{2}\right), 3.40-3.52(\mathrm{~m}, 4 \mathrm{H}$, 
$\left.2 \mathrm{NCH}_{2}\right), 4.34\left(\mathrm{~s}, 2 \mathrm{H}, \mathrm{Bn} \mathrm{CH} \mathrm{CH}_{2}\right), 7.06-7.26(\mathrm{~m}, 4 \mathrm{H}, \mathrm{H}-6+\mathrm{Ar} \mathrm{H}), 7.32(\mathrm{~d}, J=7.6,1 \mathrm{H}, \mathrm{Ar} \mathrm{H}), 7.91(\mathrm{~d}, J=7.2$, $1 \mathrm{H}, \mathrm{H}-7), 8.38(\mathrm{~d}, J=7.2,1 \mathrm{H}, \mathrm{H}-5) .{ }^{13} \mathrm{C}-\mathrm{NMR}$ spectrum, $\delta$, ppm: $25.3(2 \mathrm{C}$, pyrrolidine 3,4-CH$), 36.4(\mathrm{Bn}$ $\mathrm{CH}_{2}$ ), 47.9 (2C, pyrrolidine 2,5- $\mathrm{CH}_{2}$ ), 113.2, 125.3, 127.3, 128.0, 129.4, 129.6, 131.4, 132.4, 132.9, 134.6, 140.7, 146.3. LC/MS m/z (\%): $409.4[\mathrm{M}+\mathrm{H}]^{+}$(100.0). Anal. calcd. for $\mathrm{C}_{17} \mathrm{H}_{17} \mathrm{ClN}_{4} \mathrm{O}_{2} \mathrm{~S}_{2} \%: \mathrm{C} 49.93$, H 4.19, N 13.70, S 15.68. Found, \%: C 50.07, H 4.21, N 13.68, S 15.73.

1-(3-(4-Fluorobenzylthio)-[1,2,4]triazolo[4,3-a]pyridin-8-ylsulfonyl)-1,2,3,4-tetrahydroquinoline

(15f) According to General Procedure H, 8-(3,4-dihydroquinolin-1(2H)-ylsulfonyl)-[1,2,4]triazolo[4,3-a] pyridine-3(2H)-thione $14 \mathrm{c}(0.35 \mathrm{~g}, 1 \mathrm{mmol})$ and 4-fluorobenzyl chloride $7 \mathrm{~h}(0.16 \mathrm{~g}, 1.1 \mathrm{mmol})$ yielded 1-(3-(4-fluorobenzylthio)-[1,2,4]triazolo[4,3-a]pyridin-8-ylsulfonyl)-1,2,3,4-tetrahydroquinoline $\mathbf{1 5 f}$ $(0.42 \mathrm{~g}, 92 \%)$, as a cream solid, m.p. $113-115^{\circ} \mathrm{C},{ }^{1} \mathrm{H}-\mathrm{NMR}$ spectrum, $\delta$, ppm $(J, \mathrm{~Hz}): 2.75-2.85(\mathrm{~m}, 2 \mathrm{H}$, THQ 3- $\left.\mathrm{CH}_{2}\right), 3.60-3.70\left(\mathrm{~m}, 2 \mathrm{H}, \mathrm{CH}_{2}\right), 4.29\left(\mathrm{~s}, 2 \mathrm{H}, \mathrm{Bn} \mathrm{CH}_{2}\right), 4.46-4.53\left(\mathrm{~m}, 2 \mathrm{H}, \mathrm{CH}_{2}\right), 6.90(\mathrm{t}, J=7.6,2 \mathrm{H}$, Bn H-3,5), 7.02-7.12 (m, 5H, H-6 + Ar H), 7.18 (t, J = 7.6, 2H, Bn H-2,6), 7.96 (d, J = 7.2, 1H, H-7), 8.38 (d, $J=7.2,1 \mathrm{H}, \mathrm{H}-5) .{ }^{13} \mathrm{C}-\mathrm{NMR}$ spectrum, $\delta$, ppm: $28.3\left(\mathrm{THQ} 3-\mathrm{CH}_{2}\right), 37.6\left(\mathrm{Bn} \mathrm{CH}_{2}\right), 43.6\left(\mathrm{THQ} \mathrm{CH}_{2}\right)$, $46.7\left(\mathrm{THQ} \mathrm{CH}_{2}\right), 113.1,115.2\left(\mathrm{~d}, J_{\mathrm{CF}}=21.9 \mathrm{~Hz}, 2 \mathrm{C}\right.$, Bn C-3,5), 125.4, 126.1, 126.2, 126.6, 128.4, 128.6, $130.9\left(\mathrm{~d}, J_{C F}=8.3 \mathrm{~Hz}, 2 \mathrm{C}\right.$, Bn C-2,6), 131.8, 132.0, 133.3, 133.4, 141.3, 145.9, $161.5\left(\mathrm{~d}, J_{C F}=244 \mathrm{~Hz}\right.$, Bn C-4). LC/MS m/z (\%): $455.3[\mathrm{M}+\mathrm{H}]^{+}$(100.0). Anal. calcd. for $\mathrm{C}_{22} \mathrm{H}_{19} \mathrm{FN}_{4} \mathrm{O}_{2} \mathrm{~S}_{2} \%$ : C 58.13, $\mathrm{H} 4.21$, N 12.33, S 14.11. Found, \%: C 57.98, H 4.19, N 12.38, S 14.14.

\subsection{Antimalarial Activity Assay}

The in vitro antiplasmodial activity of all synthesized compounds was evaluated at the Laboratory of Microbiology, Parasitology and Hygiene (LMPH, University of Antwerp, Belgium) against red blood cells of chloroquine-resistant P. falciparum 2/K strain.

Stock solutions were prepared in $100 \% \mathrm{DMSO}$ at $20 \mathrm{mg} / \mathrm{mL}$ just prior to screening. For the tests, appropriate reference drugs were used as positive control: tamoxifen for MRC-5, chloroquine for P. falciparum. Reference drugs were either obtained from the fine chemical supplier Sigma or from WHO-TDR.

The integrated panel of microbial screens and standard screening methodologies was adopted as previously described [48]. All assays were performed in triplicate at the Laboratory of Microbiology, Parasitology and Hygiene at the University of Antwerp, Belgium. Compounds were tested at five concentrations $(64,16,4,1$ and $0.25 \mu \mathrm{g} / \mathrm{mL})$ to establish a full dose-titration and determination of the $\mathrm{IC}_{50}$ (inhibitory concentration 50\%). The in-test concentration of DMSO did not exceed $0.5 \%$. The selectivity antiprotozoal potential was assessed by simultaneous evaluation of cytotoxicity on a fibroblast (MRC-5) cell line. The criterion for activity was an $\mathrm{IC}_{50}<10 \mu \mathrm{g} / \mathrm{mL}$ and a selectivity index of $\geq 4$.

\subsubsection{Antiplasmodial Activity}

Chloroquine-resistant P. falciparum 2/K 1-strain was cultured in human erythrocytes $\mathrm{O}+$ at $37^{\circ} \mathrm{C}$ under a low oxygen atmosphere $\left(3 \% \mathrm{O}_{2}, 4 \% \mathrm{CO}_{2}\right.$, and $\left.93 \% \mathrm{~N}_{2}\right)$ in RPMI-1640, supplemented with $10 \%$ human serum. Infected human red blood cells $(200 \mu \mathrm{L}, 1 \%$ parasitaemia, $2 \%$ haematocrit) were added to each well and incubated for $72 \mathrm{~h}$. After incubation, test plates were frozen at $-20^{\circ} \mathrm{C}$. Parasite multiplication was measured by the Malstat method [48,49].

\subsubsection{Cytotoxicity Assay}

MRC-5 SV2 cells were cultivated in MEM, supplemented with L-glutamine (20 mMol), $16.5 \mathrm{mMol}$ sodium hydrogen carbonate and 5\% FCS. For the assay, 104 MRC- 5 cells/well were seeded onto the test plates containing the pre-diluted sample and incubated at $37^{\circ} \mathrm{C}$ and $5 \% \mathrm{CO}_{2}$ for $72 \mathrm{~h}$. Cell viability was assessed fluorimetrically after $4 \mathrm{~h}$ of addition of resazurin. Fluorescence was measured (excitation $550 \mathrm{~nm}$, emission $590 \mathrm{~nm}$ ) and the results were expressed as \% reduction in cell viability compared to control. 


\section{Conclusions}

In order to develop new antimalarial drugs, a virtual library with three randomization points for novel [1,2,4] triazolo [4,3-a] pyridines bearing a sulfonamide moiety was designed. By means of virtual screening and molecular docking techniques using falcipain-2 as a target, 25 final compounds were chosen for synthesis and in vitro screening for their antimalarial activity against Plasmodium falciparum. 3-Ethyl-N-(3-fluorobenzyl)-N-(4-methoxyphenyl)-[1,2,4]triazolo[4,3-a]pyridine-6-sulfonamide and 2-(3-chlorobenzyl)-8-(piperidin-1-ylsulfonyl)-[1,2,4]triazolo[4,3-a]pyridin-3(2H)-one showed, in vitro, good antimalarial activity with inhibitory concentration $\mathrm{IC}_{50}=2.24$ and $4.98 \mu \mathrm{M}$, respectively. This new series of compounds may serve as a starting point for future antimalarial drug discovery programs.

Supplementary Materials: The ${ }^{1} \mathrm{H}-\mathrm{NMR},{ }^{13} \mathrm{C}-\mathrm{NMR}$ spectra of compounds and LCMS data are available online.

Author Contributions: Conceptualization, S.M.K. and N.D.B.; Data curation, S.S.K. and V.R.K.; Funding acquisition, T.L.; Project administration, L.M.; Software, V.V.I. and T.L.; Supervision, S.M.K.; Writing-original draft, O.G.D., V.A.G. and L.M.; Writing—review and editing, O.G.D. All authors have read and agreed to the published version of the manuscript.

Funding: This research received no external funding.

Acknowledgments: The authors thank Ann Matheeussen and Margot Desmet for performing the in vitro evaluation of the compounds.

Conflicts of Interest: The authors confirm that this article content has no conflict of interest.

\section{References}

1. Ogungbe, I.V.; Setzer, W.N. The Potential of Secondary Metabolites from Plants as Drugs or Leads against Protozoan Neglected Diseases-Part III: In-Silico Molecular Docking Investigations. Molecules 2016, 21, 1389. [CrossRef] [PubMed]

2. World Malaria Report 2019. Geneva: World Health Organization; 2019. Licence: CC BY-NC-SA 3.0 IGO. Available online: https://www.who.int/publications-detail/world-malaria-report-2019 (accessed on 29 September 2020).

3. Sutherland, C.J.; Tanomsing, N.; Nolder, D.; Oguike, M.; Jennison, C.; Pukrittayakamee, S.; Dolecek, C.; Hien, T.T.; do Rosario, V.E.; Arez, A.P.; et al. Two nonrecombining sympatric forms of the human malaria parasite Plasmodium ovale occur globally. J. Infect. Dis. 2010, 201, 1544-1550. [CrossRef] [PubMed]

4. Shah, F.; Mukherjee, P.; Gut, J.; Legac, J.; Rosenthal, P.J.; Tekwani, B.L.; Avery, M.A. Identification of novel malarial cysteine protease inhibitors using structure-based virtual screening of a focused cysteine protease inhibitor library. J. Chem. Inf. Model. 2011, 51, 852-864. [CrossRef] [PubMed]

5. Pandey, R.K.; Narula, A.; Naskar, M.; Srivastava, S.; Verma, P.; Malik, R.; Shah, P.; Prajapati, V.K. Exploring dual inhibitory role of febrifugine analogues against Plasmodium utilizing structure-based virtual screening and molecular dynamic simulation. J. Biomol. Struct. Dyn. 2017, 35, 791-804. [CrossRef] [PubMed]

6. Meissner, K.A.; Kronenberger, T.; Maltarollo, V.G.; Trossini, G.H.G.; Wrenger, C. Targeting the Plasmodium falciparum plasmepsin V by ligand-based virtual screening. Chem. Biol. Drug Des. 2019, 93, 300-312. [CrossRef]

7. Pavadai, E.; El Mazouni, F.; Wittlin, S.; de Kock, C.; Phillips, M.A.; Chibale, K. Identification of New Human Malaria Parasite Plasmodium falciparum Dihydroorotate Dehydrogenase Inhibitors by Pharmacophore and Structure-Based Virtual Screening. J. Chem. Inf. Model. 2016, 56, 548-562. [CrossRef]

8. McKay, P.B.; Peters, M.B.; Carta, G.; Flood, C.T.; Dempsey, E.; Bell, A.; Berry, C.; Lloyd, D.G.; Fayne, D. Identification of plasmepsin inhibitors as selective anti-malarial agents using ligand based drug design. Bioorg. Med. Chem. Lett. 2011, 21, 3335-3341. [CrossRef]

9. Vyas, V.K.; Qureshi, G.; Ghate, M.; Patel, H.; Dalai, S. Identification of novel PfDHODH inhibitors as antimalarial agents via pharmacophore-based virtual screening followed by molecular docking and in vivo antimalarial activity. SAR QSAR Environ. Res. 2016, 27, 427-440. [CrossRef]

10. Danylchenko, S.Y.; Kovalenko, S.S.; Drushlyak, O.G.; Kovalenko, S.M.; Maes, L. $[1,2,4]$ triazolo[4,3-a]quinazolin-5-one derivatives as antimalarial agents. Ukr. Biopharm. J. 2016, 1, 78-83. [CrossRef] 
11. Prakash, O.; Hussain, K.; Aneja, D.K.; Sharma, C.; Aneja, K.R. A facile iodine(III)-mediated synthesis of 3-(3-aryl-1-phenyl-1H-pyrazol-4-yl)-[1,2,4]triazolo[4,3-a]pyridines via oxidation of 2-((3-aryl-1-phenyl-1H-pyrazol-4-yl)methylene)-1-(pyridin-2-yl)hydrazines and their antimicrobial evaluations. Org. Med. Chem. Lett. 2011, 1, 1. [CrossRef]

12. Rucker, P.V.; Jerome, K.W.; Selness, S.R.; Baldus, J.E.; Xing, L. Preparation of Triazolopyridine Compounds as p38 Kinase, TNF, and Cyclooxygenase Inhibitors for the Treatment of Inflammation. WO 2006018735 A2, 23 February 2006.

13. Chen, C.; Deng, H.; Guo, H.; He, F.; Jiang, L.; Liang, F.; Mi, Y.; Wan, H.; Xu, Y.C.; Yu, H.; et al. 6-substituted 3-(quinolin-6-yl-thio)-[1,2,4]triazolo[4,3-a]pyradines as Tyrosine Kinase. WO 2013038362 A1, 21 March 2013.

14. Alcaraz, L.; Panchal, T.A.; Jennings, A.S.R.; Cridland, A.; Hurley, C. Derivatives of [1,2,4]triazolo[4,3-a]pyridine as p38-MAP Kinase Inhibitors. WO Patent 2014194956 A1, 11 December 2014.

15. Liu, X.H.; Xu, X.Y.; Tan, C.X.; Weng, J.Q.; Xin, J.H.; Chen, J. Synthesis, crystal structure, herbicidal activities and 3D-QSAR study of some novel 1,2,4-triazolo[4,3-a]pyridine derivatives. Pest Manag. Sci. 2015, 71, 292-301. [CrossRef] [PubMed]

16. Maehata, R.; Shimomura, M. Preparation of Fused Heterocyclic Compounds as Pesticides against Harmful Arthropods. WO 2018139436 A1, 2 August 2018.

17. Guan, L.P.; Zhang, R.P.; Sun, Y.; Chang, Y.; Sui, X. Synthesis and studies on the anticonvulsant activity of 5-alkoxy-[1,2,4]triazolo[4,3-a]pyridine derivatives. Arzneimittelforschung 2012, 62, 372-377. [CrossRef] [PubMed]

18. Cid-Núñez,J.M.; Trabanco-Suárez, A.A.; Lavreysen,H.; Ceusters, M. 1,2,4-triazolo[4,3-a]pyridine Compounds and Their Use as Positive Allosteric Modulators of mGluR2 Receptors. WO 2015032790 A1, 12 March 2015.

19. Lavreysen, H.; Langlois, X.; Donck, L.V.; Cid-Núñez, J.M.; Pype, S.; Lütjens, R.; Megens, A. Preclinical evaluation of the antipsychotic potential of the mGlu2-positive allosteric modulator JNJ-40411813. Pharmacol. Res. Perspect. 2015, 3, e00097. [CrossRef] [PubMed]

20. Cole, B.M.; Nugent, R.A.; Smith, P.T. Preparation of Triazolopyridine Compounds for the Treatment of Cystic Fibrosis. U.S. 20160096835 A1 7 April 2016.

21. Haggie, P.M.; Phuan, P.-W.; Tan, J.-A.; Xu, H.; Avramescu, R.G.; Perdomo, D.; Zlock, L.; Nielson, D.W.; Finkbeiner, W.E.; Lukacs, G.L.; et al. Correctors and Potentiators Rescue Function of the Truncated W1282X-Cystic Fibrosis Transmembrane Regulator (CFTR) Translation Product. J. Biol. Chem. 2017, 292, 771-785. [CrossRef] [PubMed]

22. Kumar, S.; Bhardwaj, T.R.; Prasad, D.N.; Singh, R.K. Drug targets for resistant malaria: Historic to future perspectives. Biomed. Pharmacother. 2018, 104, 8-27. [CrossRef]

23. Matondo, S.I.; Temba, G.S.; Kavishe, A.A.; Kauki, J.S.; Kalinga, A.; van Zwetselaar, M.; Reyburn, H.; Kavishe, R.A. High levels of sulphadoxine-pyrimethamine resistance Pfdhfr-Pfdhps quintuple mutations: A cross sectional survey of six regions in Tanzania. Malar. J. 2014, 13, 152. [CrossRef]

24. Wise, D.L.; Gresser, J.D.; McCormick, G.J. Sustained release of a dual antimalarial system. J. Pharm. Pharmacol. 1979, 31, 201-204. [CrossRef]

25. Da Silva, L.E.; Joussef, A.C.; Pacheco, L.K.; da Silva, D.G.; Steindel, M.; Rebelo, R.A. Synthesis and in vitro evaluation of leishmanicidal and trypanocidal activities of N-quinolin-8-yl-arylsulfonamides. Bioorg. Med. Chem. 2007, 15, 7553-7560. [CrossRef]

26. Greenwood, D. Sulfonamides. In Antibiotic and Chemotherapy, 9th ed.; Finch, R.G., Greenwood, D., Whitley, R.J., Norrby, S.R., Eds.; Elsevier: Philadelphia, PA, USA, 2010; Chapter 29; pp. 337-343.

27. Martyn, D.C.; Cortese, J.F.; Tyndall, E.; Dick, J.; Mazitschek, R.; Munoz, B.; Clardy, J. Antiplasmodial activity of piperazine sulfonamides. Bioorg. Med. Chem. Lett. 2010, 20, 218-221. [CrossRef]

28. Ekoue-Kovi, K.; Yearick, K.; Iwaniuk, D.P.; Natarajan, J.K.; Alumasa, J.; de Dios, A.C.; Roepe, P.D.; Wolf, C. Synthesis and antimalarial activity of new 4-amino-7-chloroquinolylamides, sulfonamides, ureas and thioureas. Bioorg. Med. Chem. 2009, 17, 270-283. [CrossRef]

29. Krungkrai, J.; Krungkrai, S.R.; Supuran, C.T. Carbonic anhydrase inhibitors: Inhibition of Plasmodium falciparum carbonic anhydrase with aromatic/heterocyclic sulfonamides-In vitro and in vivo studies. Bioorg. Med. Chem. Let. 2008, 18, 5466-5471. [CrossRef] [PubMed]

30. Pandey, K.C.; Dixit, R. Structure-Function of Falcipains: Malarial Cysteine Proteases. J. Trop. Med. 2012, 1-11. [CrossRef] [PubMed]

31. Ettari, R.; Bova, F.; Zappala, M.; Grasso, S.; Micale, N. Falcipain-2 Inhibitors. Med. Res. Rev. 2009, $136-167$. [CrossRef] [PubMed] 
32. Sharma, R.K.; Younis, Y.; Mugumbate, G.; Njoroge, M.; Gut, J.; Rosenthal, P.J.; Chibale, K. Synthesis and structure-activity-relationship studies of thiazolidinediones as antiplasmodial inhibitors of the Plasmodium falciparum cysteine protease falcipain-2. Eur. J. Med. Chem. 2015, 90, 507-518. [CrossRef]

33. Qidwai, T. Hemoglobin Degrading Proteases of Plasmodium falciparum as Antimalarial Drug Targets. Curr. Drug Targets 2015, 16, 1133-1141. [CrossRef]

34. Shenai, B.R.; Sijwali, P.S.; Singh, A.; Rosenthal, P.J. Characterization of Native and Recombinant Falcipain-2, a Principal Trophozoite Cysteine Protease and Essential Hemoglobinase of Plasmodium falciparum. J. Biol. Chem. 2000, 275, 29000-29010. [CrossRef]

35. Kerr, I.D.; Lee, J.H.; Pandey, K.C.; Harrison, A.; Sajid, M.; Rosenthal, P.J.; Brinen, L.S. Structures of falcipain-2 and falcipain-3 bound to small molecule inhibitors: Implications for substrate specificity. J. Med. Chem. 2009, 52, 852-857. [CrossRef]

36. Arafet, K.; Ferrer, S.; Martí, S.; Moliner, V. Quantum Mechanics/Molecular Mechanics Studies of the Mechanism of Falcipain-2 Inhibition by the Epoxysuccinate E64. Biochemistry 2014, 53, 3336-3346. [CrossRef]

37. Wolber, G.; Dornhofer, A.A.; Langer, T. Efficient overlay of small organic molecules using 3D pharmacophores. J. Comput. Aided Mol. Des. 2006, 20, 773-788. [CrossRef]

38. Postovskii, I.Y.; Kotovskaya, S.K.; Mokrushina, G.A.; Il'enko, V.I.; Platonov, V.G.; Polonyankin, A.V. Synthesis and properties of pyridine sulfamides and s-triazolo[4,3-a]pyridines. Khim. Farm. Zh. 1980, 14, 50-54. [CrossRef]

39. Rutkowska, E.; Pajak, K.; Jóźwiak, K. Lipophilicity-Methods of determination and its role in medicinal chemistry. Acta Pol. Pharm. 2013, 70, 3-18. [PubMed]

40. Clark, D.E. Rapid calculation of polar molecular surface area and its application to the prediction of transport phenomena. 1. Prediction of intestinal absorption. J. Pharm. Sci. 1999, 88, 807-814. [CrossRef] [PubMed]

41. Lipinski, C.A.; Lombardo, F.; Dominy, B.W.; Feeney, P.J. Experimental and computational approaches to estimate solubility and permeability in drug discovery and development settings. Adv. Drug Deliv. Rev. 2001, 46, 3-26. [CrossRef]

42. Daina, A.; Michielin, O.; Zoete, V.SwissADME: A free web tool to evaluate pharmacokinetics, druglikeness and medicinal chemistry friendliness of small molecules. Sci. Rep. 2017, 7, 42717. [CrossRef] [PubMed]

43. Zhou, S.-F. Structure, function and regulation of P-glycoprotein and its clinical relevance in drug disposition. Xenobiotica 2008, 38, 802-832. [CrossRef] [PubMed]

44. Kaserer, T.; Beck, K.R.; Akram, M.; Odermatt, A.; Schuster, D. Pharmacophore Models and Pharmacophore-Based Virtual Screening: Concepts and Applications Exemplified on Hydroxysteroid Dehydrogenases. Molecules 2015, 20, 22799-22832. [CrossRef]

45. Wolber, G.; Langer, T. LigandScout: 3-D pharmacophores derived from proteinbound ligands and their use as virtual screening filters. J. Chem. Inf. Model. 2005, 45, 160-169. [CrossRef]

46. Berman, H.M.; Westbrook, J.; Feng, Z.; Gilliland, G.; Bhat, T.N.; Weissig, H.; Shindyalov, I.N.; Bourne, P.E. The protein Data Bank. Nucleic Acids Res. 2000, 28, 235-242. [CrossRef]

47. Trott, O.; Olson, A.J. AutoDock Vina: Improving the speed and accuracy of docking with a new scoring function, efficient optimization and multithreading. J. Comput. Chem. 2010, 31, 455-461. [CrossRef]

48. Cosa, P.; Vlietinck, A.J.; Van den Berghe, D.; Maes, L. Anti-infective potential of natural products: How to develop a stronger in vitro 'proof-of-concept'. J. Ethnopharmacol. 2006, 106, 290-302. [CrossRef]

49. Makler, M.T.; Ries, J.M.; Williams, J.A.; Bancroft, J.E.; Piper, R.C.; Gibbins, B.L.; Hinrichs, D.J. Parasite lactate dehydrogenase as an assay for Plasmodium falciparum drug sensitivity. Am. J. Trop. Med. Hyg. 1993, 48, 739-741. [CrossRef] [PubMed]

Sample Availability: Samples of the compounds are not available from the authors. 